\title{
18. RADIOLARIA OF LEG 10 WITH SYSTEMATICS AND RANGES FOR THE FAMILIES AMPHIPYNDACIDAE, ARTOSTROBIIDAE, AND THEOPERIDAE
}

\author{
Helen P. Foreman, Department of Geology, Oberlin College, Oberlin, Ohio
}

\section{CONTENTS}

Introduction

407

Recommendation for future drilling

407

Material treated and presentation of results

Radiolarians from each Hole

Radiolarians from Hole 86 with

Tables $1 \mathrm{a}$ and $1 \mathrm{~b}$

Radiolarians from Hole 94 with

Tables $2 \mathrm{a}$ and $2 \mathrm{~b}$

Radiolarians from Hole 95 with

Tables $3 \mathrm{a}$ and $3 \mathrm{~b}$

Radiolarians from Hole 96 with

Tables $4 \mathrm{a}$ and $4 \mathrm{~b}$

Radiolarians from Hole 97 with Table 5a

Stratigraphic results and radiolarian zonation

List of events, Table 6

407

408

408

408

409

409

409

409

409
Range chart, Figure 1

416

Correlation chart, Figure 2

425

Radiolarian zonation and Table 7

425

Zonation of Leg 10 cores on the basis of radiolarians, foraminifera and nannofossils, Figure 3

New information on phylogeny 428

Systematic section

Cretaceous Radiolaria $\quad 429$

Hole $95 \quad 429$

Age 430

Hole $97 \quad 430$

Age $\quad 430$

Tertiary Radiolaria $\quad 430$

References $\quad 442$

Plates 444

Index 472

\section{INTRODUCTION}

Radiolaria in significant quantities were recovered from holes drilled at five of the thirteen sites investigated. Their localities are as follows:

Hole 86: $22^{\circ} 52.75^{\prime} \mathrm{N}, 90^{\circ} 57.55^{\prime} \mathrm{W}$; depth of water 1481 meters.

Hole $94: 24^{\circ} 31.64^{\prime} \mathrm{N}, 88^{\circ} 28.16^{\prime} \mathrm{W}$; depth of water 1793 meters.

Hole 95: $24^{\circ} 08.8^{\prime} \mathrm{N}, 86^{\circ} 23.9^{\prime} \mathrm{W}$; depth of water 1633 meters.

Hole 96: $23^{\circ} 44.56^{\prime} \mathrm{N}, 85^{\circ} 45.8^{\prime} \mathrm{W}$; depth of water 3439 meters.

Hole 97: $23^{\circ} 53.05^{\prime} \mathrm{N}, 84^{\circ} 26.74^{\prime} \mathrm{W}$; depth of water 2930 meters.

The first four holes, from which generally abundant, well-preserved Radiolaria were recovered, were along the Campeche Bank, and the last hole which contained only rare, less well-preserved Radiolaria was situated on the western approach to the Florida straits.

Two poorly preserved isolated samples of Upper Cretaceous Radiolaria were recovered, Early Campanian in Hole 95 and Early Cenomanian in Hole 97 . Tertiary Radiolaria were recovered as follows: Late Paleocene in Holes 94 and 96; Early Eocene in Holes 94, 95, and 96; Middle Eocene in Holes 94 and 95; Late Eocene in Holes 86, 94, 95, and 97; Early Oligocene in Holes 94 and 95; Late Oligocene in Holes 86, 94, 95, and 96; and Early Miocene in Hole 94. Extremely rare Quaternary Radiolaria were found in the core catcher samples of the first core in most of the holes.

Two points of particular interest are the co-occurrence of all the Radiolaria, except the Early Cenomanian, with calcareous microfossils and the presence of well-preserved Early Eocene and Late Paleocene Radiolaria. While the co-occurrence of Radiolaria with the calcareous microfossils in sediments of Miocene and Oligocene age is not so unusual, their co-occurrence and recovery in older sediments, i.e., Eocene and Late Paleocene, in a long sequence, is unique and has produced results of fundamental significance.

\section{RECOMMENDATION FOR FUTURE DRILLING}

Because of the limiting factors of time, bit durability, and poor recovery in the Early Eocene, Hole 94 was not continuously cored except in the early Middle Eocene and the Late Paleocene-Cretaceous. It seems apparent from the cores that were recovered that a complete sequence of well-preserved Radiolaria, together with well-preserved calcareous microfossils from late Early Miocene through the early Early Eocene (with the exception of a hiatus in the late Middle Eocene) may be present in this hole. As such a long, well-preserved, virtually complete sequence of Radiolaria of comparable age has not been encountered in any other hole drilled in the DSDP program so far, it is suggested that at some future date this site be redrilled to pick up the missing sections.

\section{MATERIAL TREATED AND PRESENTATION OF RESULTS}

Cretaceous Radiolaria and Tertiary Radiolaria belonging to the families Amphipyndacidae, Artostrobiidae, and 
Theoperidae are treated here. The other families are treated by Sanfilippo and Riedel in another chapter of this volume.

Only two samples of poorly preserved Cretaceous Radiolaria were recovered. The samples are described and some species illustrated.

In the Tertiary, the Late Paleocene and Early Eocene samples are of the greatest interest and have provided the opportunity for adding materially to our knowledge of Radiolaria. Thus the main part of this work is concerned with the Radiolaria from that time span. Radiolaria from the younger, less complete sequences which are better known have been less thoroughly studied.

For the older material (i.e., the Late Paleocene to Middle Eocene) new taxa have been described and four new zones defined. Occurrences for all of the new and many previously described species have been recorded with their relative abundance on tabulation charts (Tables 1B-4B). From this data a list of events (Table 6) has been made which gives, in chronological order, the first and last appearance and evolutionary transitions for each species in each hole and so serves to correlate in detail from one hole to another. A range chart (Figure 1), based on a composite of not quite overlapping sections from Holes 94, 96, and 86 , presents the data in summary form together with correlations for the calcareous microfossils determined by $\mathrm{B}$. McNeely and L. Smith. A synchronopticon (Plates 1-8) illustrates many of the species from five levels in this older material. These plates when read vertically show the evolutionary change within a species and among related species. Read horizontally they indicate which species occur simulataneously at each of the five levels. Plates 9-12 illustrate the new species and all other species for which ranges are given on the range chart at a larger magnification than was possible in the synchronopticon, and Plate 13 illustrates Cretaceous forms.

For the younger material (i.e., the Late Eocene to Early Miocene) occurrences of previously described species have been recorded on tabulation charts (Tables $1 \mathrm{~A}-5 \mathrm{~A}$ ) and these occurrences have been arranged in a continuation of the events list described above. One new species has been described, a robust, easily recognizable form (Lychnocanoma amphitrite) which in Core 97-5 was the only distinctive form preserved and so may be potentially useful for correlation in sediments where preservation of the Radiolaria is poor.

In the list of events and the range chart the first and last appearance of a taxon is indicated as being evolutionary $e$ when the ancestor or descendant of a taxon is known, or morphotypic $m$ when no ancestor or descendant is known, or, if known, the details of the evolutionary transition are not well enough understood to establish an evolutionary boundary. For discussion of this concept in detail, see Riedel and Sanfilippo (1971). A third type of first appearance, morphotypic-evolutionary $m-e$, wherein a taxon branches off and co-occurs for some period of time with its ancestor, is defined in this report in a separate chapter by Sanfilippo and Riedel.

\section{RADIOLARIANS FROM EACH HOLE}

Tertiary radiolarians from Holes $86,94,95,96$, and 97 have been tabulated. Because of the long time span and the number of taxa considered, two separate tabulations, Tables A and B, have been made for each hole except Hole 97 from which information was available only for Table A. Table A includes the Radiolaria from the Early Miocene to the Late Eocene and Table B includes the Radiolaria from the early Middle Eocene to the Late Paleocene. Cretaceous Radiolaria are described verbally. Abundance of Radiolaria for each sample is indicated by: $A$ for very abundant (this category was not used for any species tabulated here); $C$ for common, indicating more than thirty specimens on a well-filled strewn slide; $F$ for few, ten to thirty specimens on a slide; $R$ for rare, three to ten specimens on a slide; and + for very rare, one or two specimens on a slide. A dot indicates an isolated occurrence; a question mark, uncertain identification; and a dash, that the species was searched for but was not found.

Preservation indicates degree of corrosion, not whether specimens are broken or have had their silica replaced. Only one sample from Hole 97 (Cretaceous, Early Cenomanian) had Radiolaria in which the silica had been replaced by calcareous material. $G$ indicates good preservation, $M$ moderate, and $P$ poor.

A column headed "Reworked and Downworked" indicates when any mixing has taken place. Radiolaria reworked from older sediments are indicated by $r$ mixing of younger Radiolaria through caving by $d$.

\section{Radiolarians from Hole 86 with Tables 1A and 1B}

Common well-preserved Tertiary Radiolaria were recovered from four of the thirteen cores drilled at this site.

Radiolarian zones represented are: Core 5, the transition from the Dorcadospyris ateuchus Zone to the Theocyrtis tuberosa Zone, and the uppermost Theocyrtis tuberosa Zone; Core 6, the Thyrsocyrtis bromia Zone. An unzoned interval, Cores 7 and 8, includes the oldest Tertiary (Late Paleocene, P4) Radiolaria recovered on Leg 10.

\section{Radiolarians from Hole 94 with Tables 2A and 2B}

Tertiary radiolarians were recovered from twenty-nine of the forty cores drilled at this site. They were well preserved but very rare from $138-258$ meters $(4, \mathrm{CC}$ TO $8, \mathrm{CC}$ ), and well preserved, abundant to common from 292.5-609 meters (9-1 to $32, \mathrm{CC}$ ).

Radiolarian zones represented are: Core 9, Calocycletta costata Zone; Core 10, Calocycletta virginis Zone; Cores 11 to 13, Theocyrtis tuberosa Zone; Cores 14 to 16, Thyrsocyrtis broma Zone; Core 17, Podocyrtis mitra Zone; Core 18, Podocyrtis ampla Zone; Cores 19 to 20, Thyrsocyrtis triacantha Zone; Core 21 to Core-section 24-3, Theocampe mongolfieri Zone; Core-sections 24-4 to 26-3, Theocotyle (T.) cryptocephala cryptocephala (?) Zone; Core-sections 26-4 to 28, CC, Phormocyrtis striata striata Zone; Cores 29 to 31, Buryella clinata Zone; and Core 32, Bekoma bidarfensis Zone.

The intervals from 362-382 meters (Cores 11-13) and 408-508 meters (Cores 14-27) were continuously cored.

A hiatus at $422-424.5$ meters (16,CC to $17-1)$ covers the interval represented by the base of the Thyrsocyrtis bromia Zone, Podocyrtis goetheana Zone, Podocyrtis chalara Zone, and the top of the Podocyrtis mitra Zone. A small hiatus or a compressed section, indicated by the abrupt 
TABLE 1A

Radiolarians from Hole 86

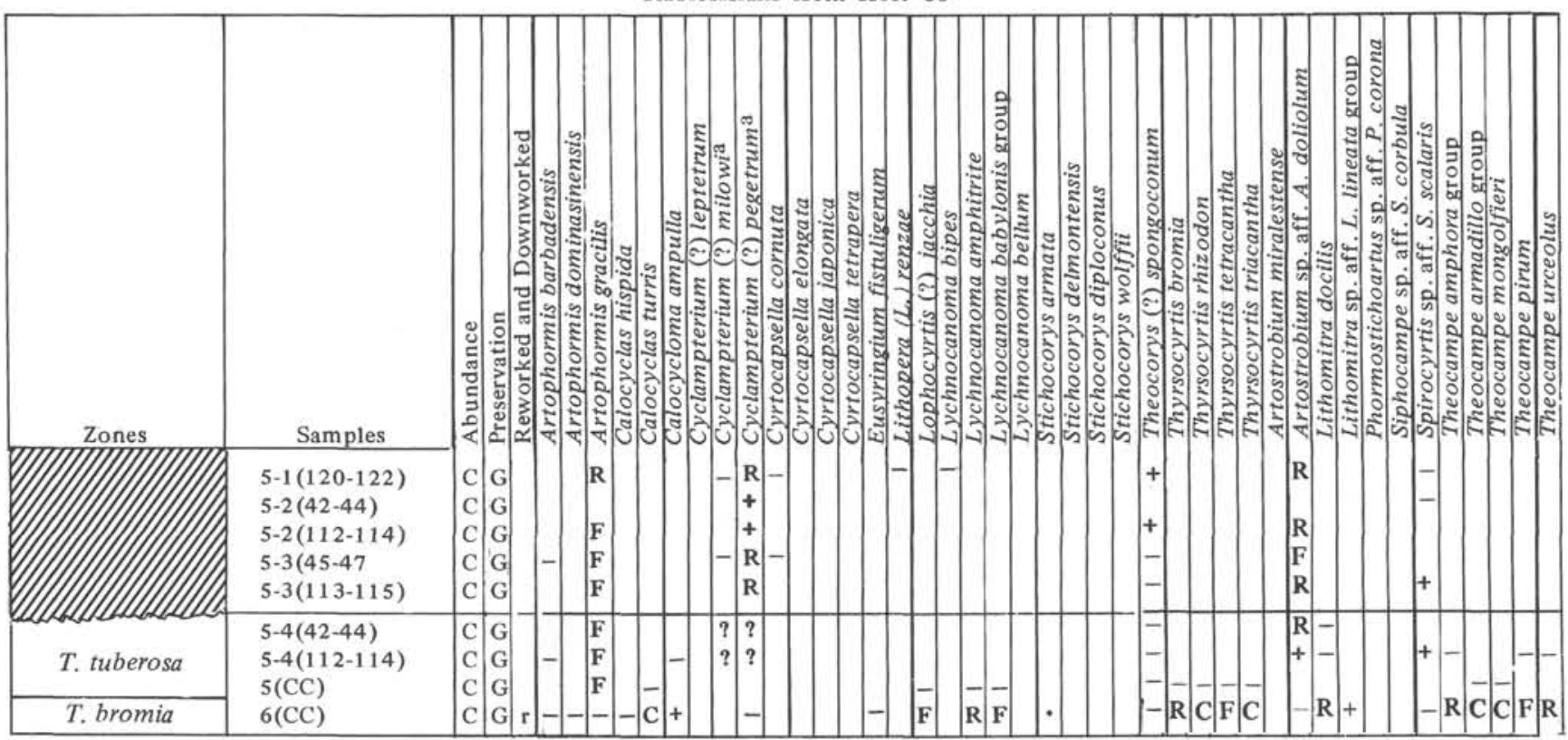

a Because the distinguishing feet are are broken off most of the specimens of $C$. pegetrum and $C$. milowi it was not always possible to distinguish confidently these two species. Rare specimens with at least one foot are indicated with + and $\cdot$ though this probably does not reflect their true abundance. A question mark indicates presence of Cyclampterium sp.

change in fauna from the Thyrsocyrtis triacantha Zone to the Theocampe mongolfieri Zone, may be present at 457 462 meters (20,CC to $21-2)$.

\section{Radiolarians from Hole 95 with Tables $3 \mathrm{~A}$ and 3B}

Abundant, well-preserved Tertiary Radiolaria were recovered from eight of the twenty-two cores drilled at this site.

Radiolarian zones represented are: Cores 2-4, the Dorcadospyris ateuchus Zone; Core 5, the Theocyrtis tuberosa Zone; Core 6, very early Thyrsocyrtis bromia Zone; Coresection 7-1, Podocyrtis ampla Zone; Core-sections 7-2 to $7-5$, the transition between the Thyrsocyrtis triacantha Zone and the Podocyrtis ampla Zone; Core-sections 7-6 to $7(\mathrm{CC})$, Thyrsocyrtis triacantha Zone; and Core 8, the Theocotyle (T.) cryptocephala cryptocephala (?) Zone. Core 9 is assigned to the Buryella clinata Zone because the transition from Phormocyrtis striata exquisita to $P$. striata striata apparently occurs between Cores 8 and 9, and also because numerous specimens of early Theocotyle (Theocotylissa) ficus are present. The apparent absence of the Phormocyrtis striata striata Zone and the co-occurrence of common members of the Theocampe amphora group with the early forms of Theocotyle (Theocotylissa) ficus are not understood.

\section{Radiolarians from Hole 96 and Tables 4A and 4B}

Tertiary Radiolaria were recovered from four of the five cores drilled at this site. They are common to abundant and well preserved at 199.5-208 meters (Core 2) and 301.5-309 meters (Core 3). They are few, with moderate to poor preservation at 321 meters (Core 4) and 330 meters (Core 5).
Radiolarian zones represented are: Core 2, the Dorcadospyris ateuchus Zone; and Core 3, the Bekoma bidarfensis Zone. An unzoned interval, Cores 4 and 5, represents Radiolaria intermediate in age between those of Core 3 and those of Cores 7 and 8 in Hole 86 .

\section{Radiolarians from Hole $\mathbf{9 7}$ and Table 5A}

Tertiary Radiolaria were recovered from three of the twelve cores drilled at this site.

At 109-111 meters (Core 2) they are rare and well preserved; at 207 meters (Core 4), Dorcadospyris ateuchus Zone, rare and well preserved; and at 251 meters (Core 5), Thyrsocyrtis bromia Zone, very rare and poorly preserved.

Cretaceous Radiolaria, Early Cenomanian, were recovered at 333 meters (Core 11). They are very rare and very poorly preserved.

\section{STRATIGRAPHIC RESULTS AND RADIOLARIAN ZONATION}

\section{List of Events, Table 6}

From the information in the tabulations a list has been made (Table 6) which gives in chronological order from youngest to oldest the events (i.e. the first or last appearance of a taxon and transitions from one taxon to another). The core sections between which an event takes place and the corresponding depth in meters below the surface are given for each event in each hole. Thus this list serves to correlate in detail from hole to hole. Ideally the events should progress downward in each hole, with correlation lines parallel. However in some cases lines cross. When this occurs, the determining factor in placing the 
TABLE 1B

Radiolarians from Hole 86

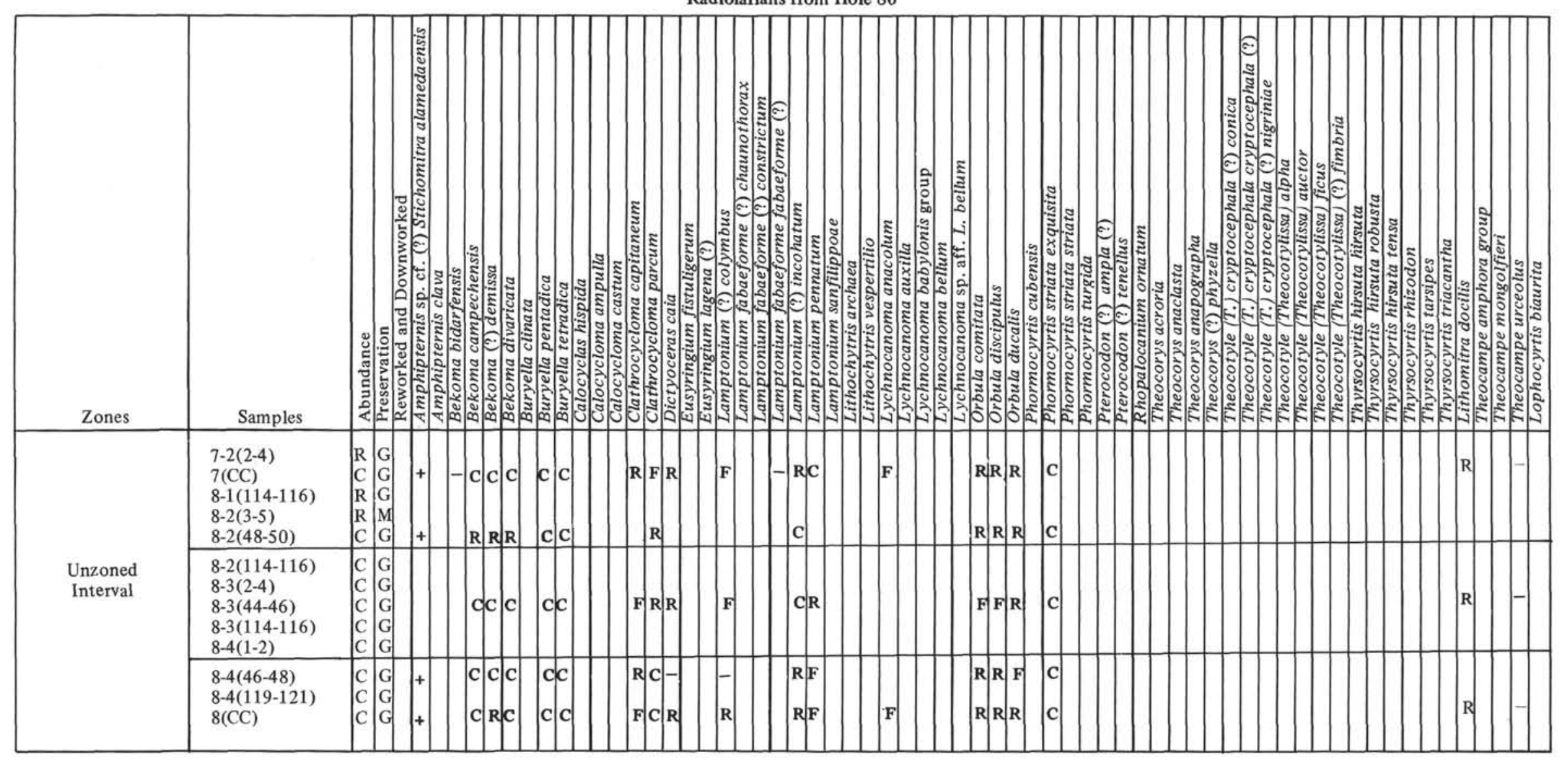


TABLE 2A

Radiolarians from Hole 94

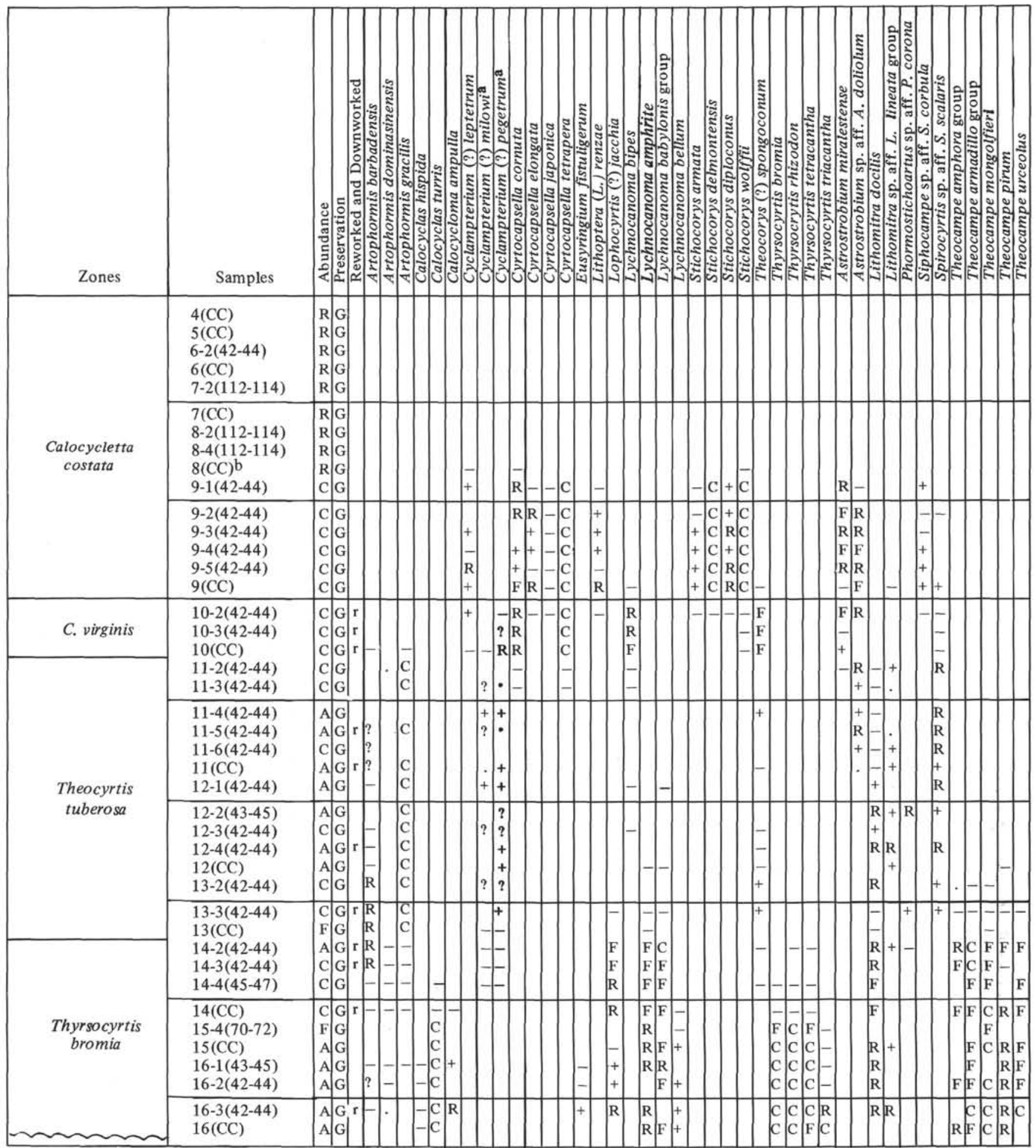

${ }^{a}$ Because the distinguishing feet are broken off most of the specimens of $C$. pegetrum and $C$. milowi it was not always possible to distinguish confidently these two species. Rare specimens with at least one foot are indicated with + and $\cdot$ though this probably does not reflect their true abundance. A question mark indicates presence of Cyclampterium sp.

${ }^{b}$ According to foraminiferal and nannoplankton data, this core is of Late Miocene age. 
TABLE 2B

Radiolarians from Hole 94

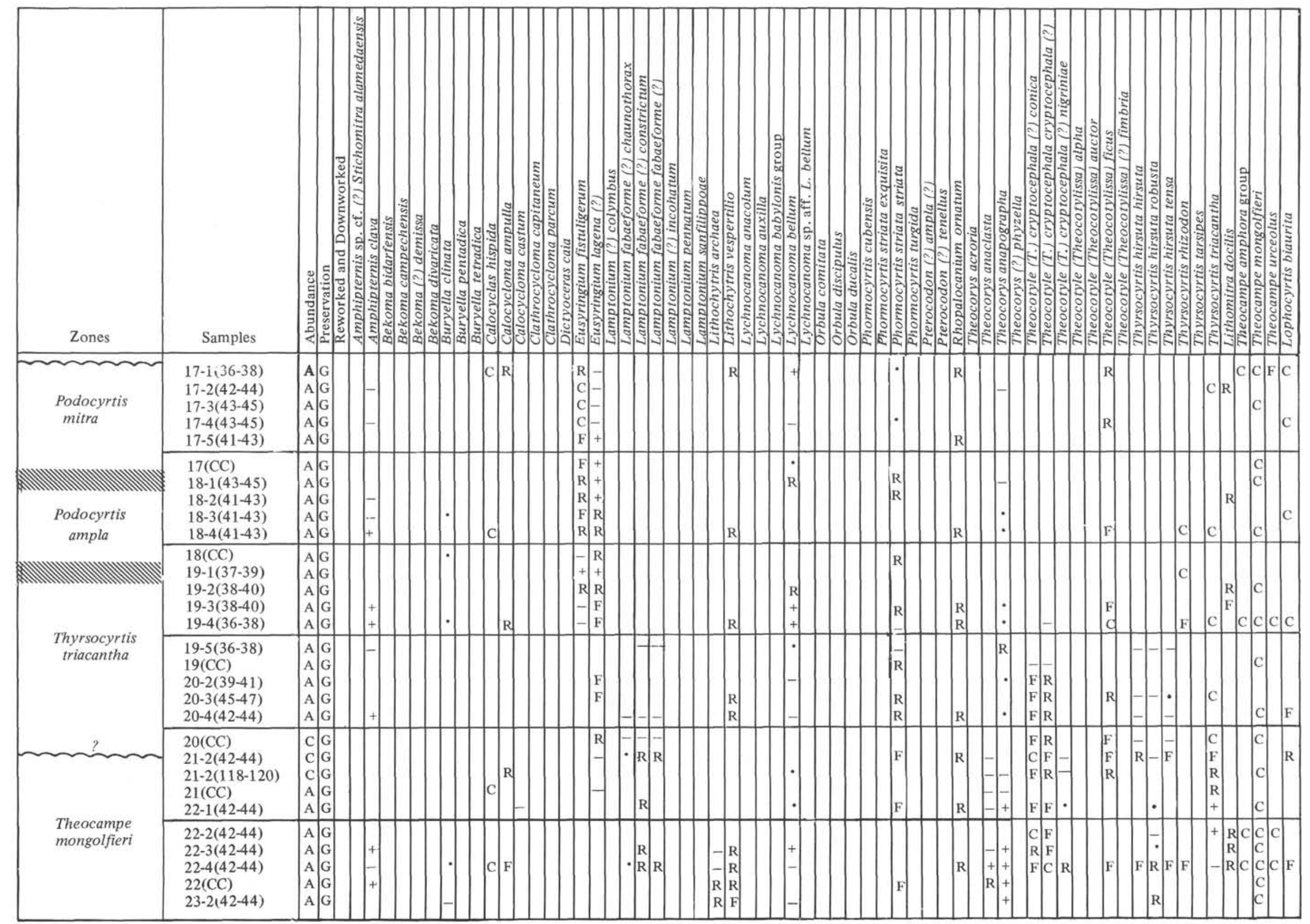




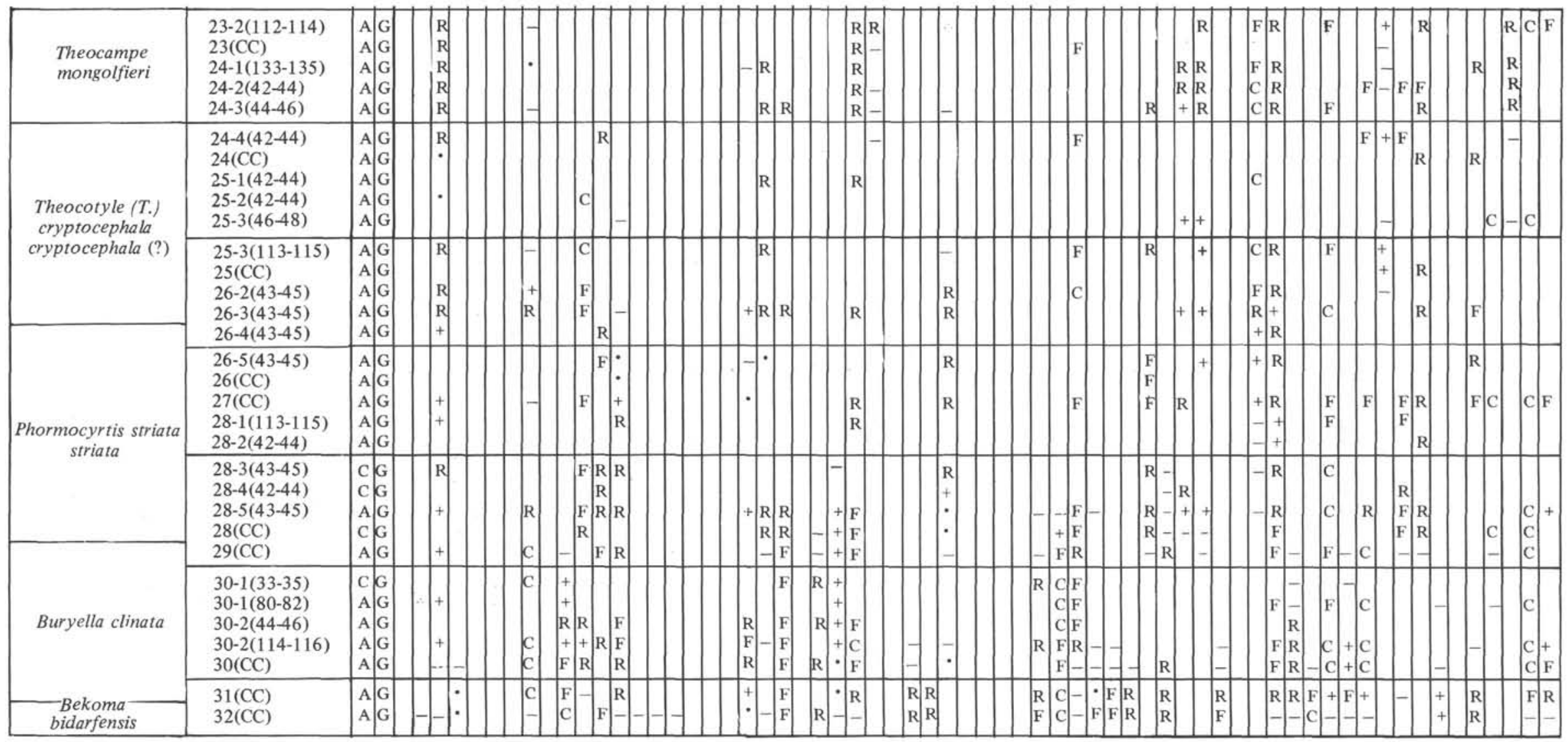


TABLE 3A

Radiolarians from Hole 95

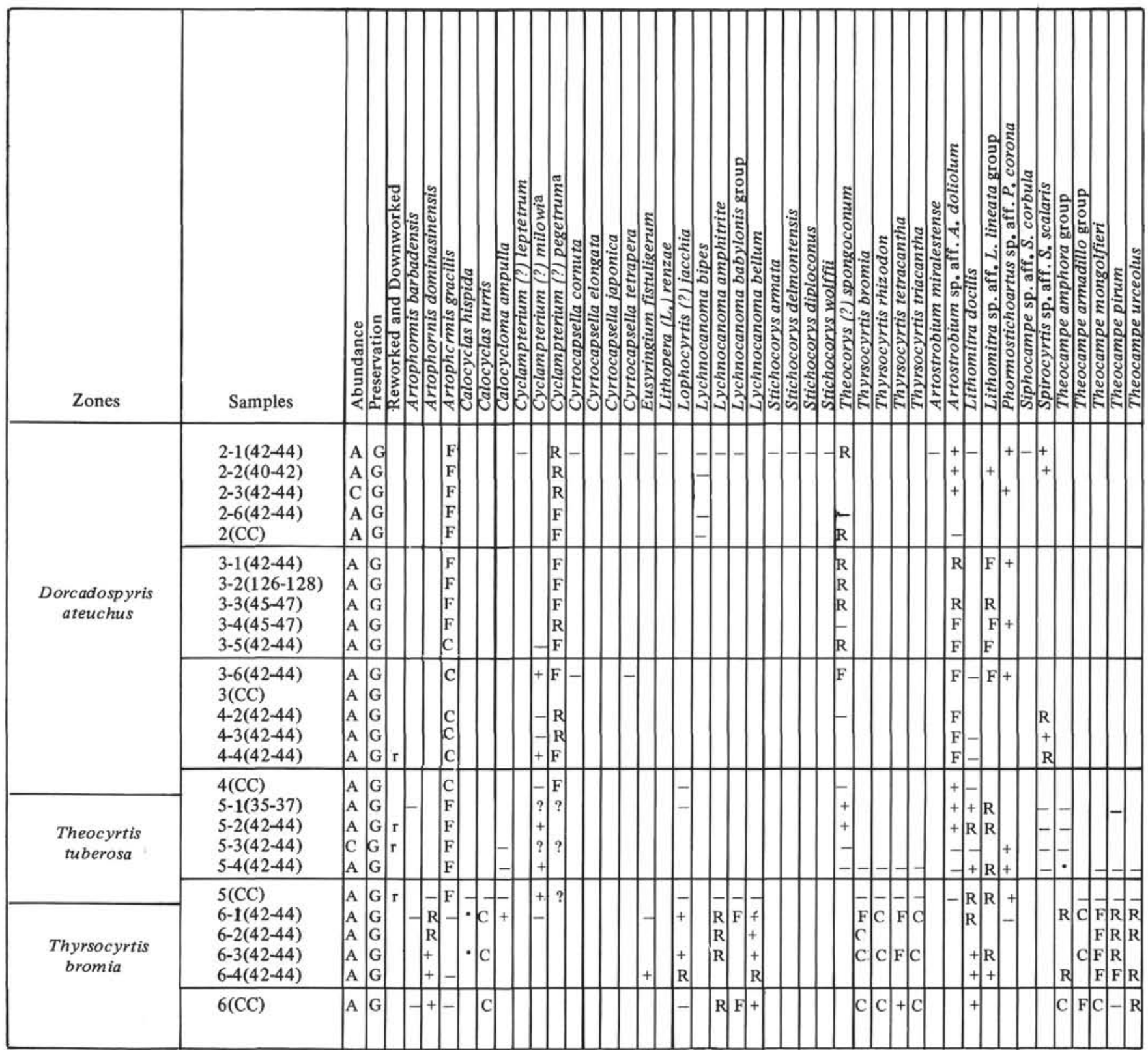

a Because the distinguishing feet are broken off most of the specimens of $C$ pegetrum and $C$. milowi it was not always possible to distinguish confidently these two species. Rare specimens with at least one foot are indicated with + and though this probably does not reflect their true abundance. A question mark indicates presence of Cyclampterium sp.

event has been its reliability, indicated as: $G$, good; $M$, moderate; and $P$, poor. Reliability criteria are based on the abundance of Radiolaria and the species in a sample, the quality of preservation of a sample, and the certainty with which the species could be distinguished from closely related forms. Other abbreviations used in the events list are: $T$, top of a taxon; $B$, base of a taxon; $m$, morphotypic top or base; $e$, evolutionary top or base; and $m-e$, morphotypic-evolutionary top or base, the latter three as indicated by accompanying $T$ or $B$.
An arrow $\rightarrow$ indicates the evolutionary change from one species to another and (000-000) gives the depth in meters below the sediment surface.

In the Leg 7 volume Riedel and Sanfilippo distinguish between $m$, morphotypic limits of a species when no ancestor or descendant is known, and $e$, evolutionary limits when the ancestor or descendant is known. In a separate chapter in this volume they further distinguish $m-e$, morphotypic-evolutionary limit, in which case a descendant cooccurs for some time with its ancestor. 
TABLE 3B

Radiolarians from Hole 95

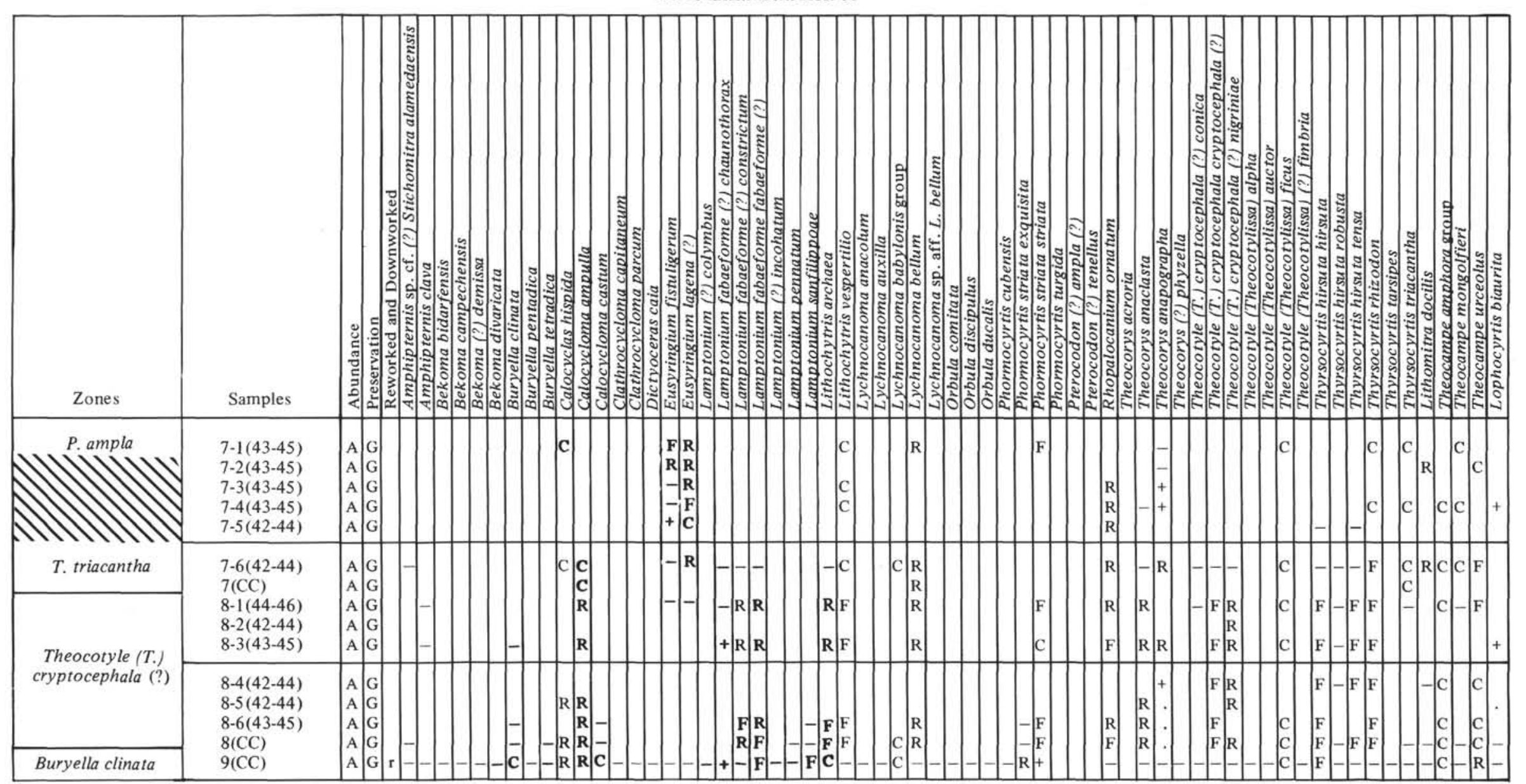


Table 4A

Radiolarians from Hole 97

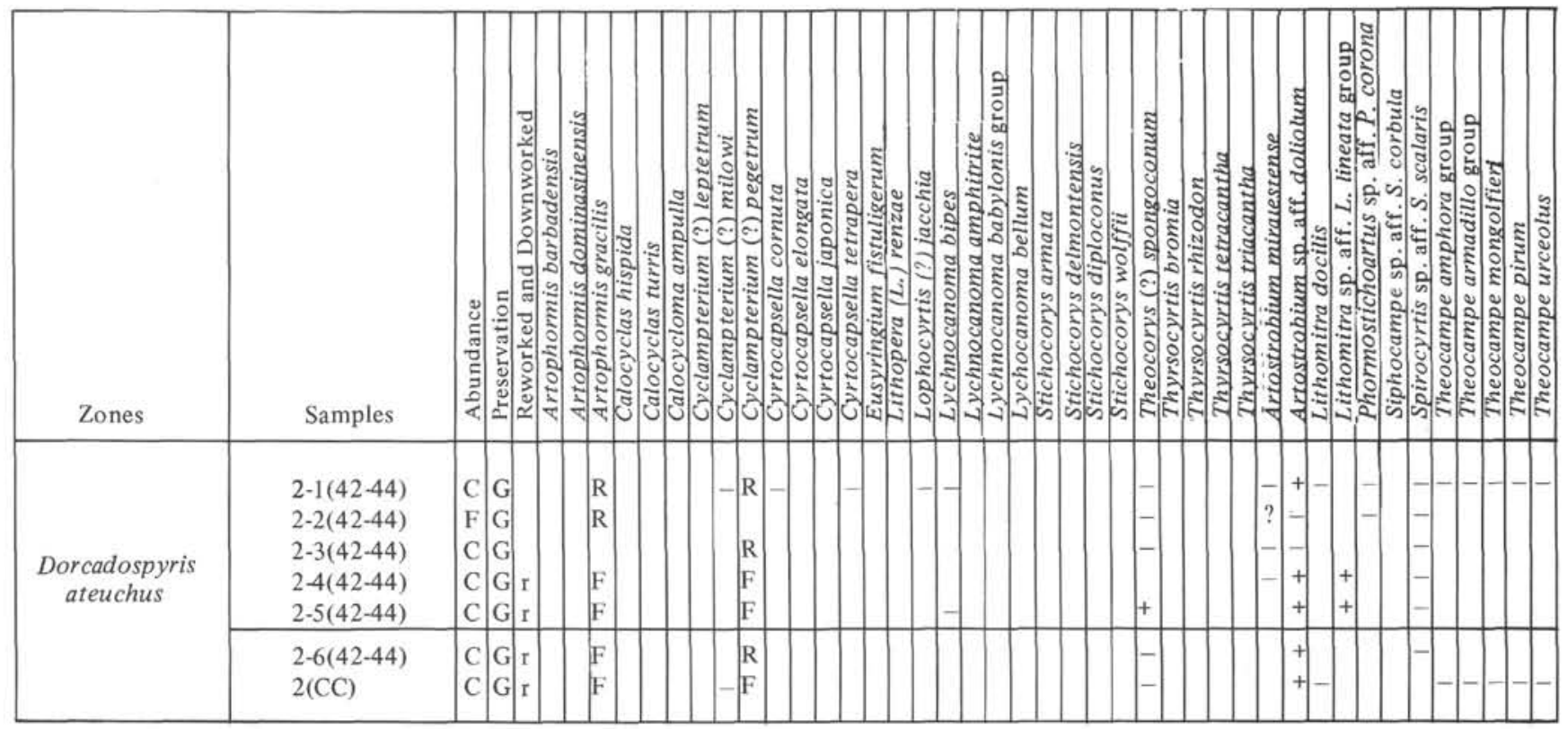

TABLE 5A

Radiolarians from Hole 97

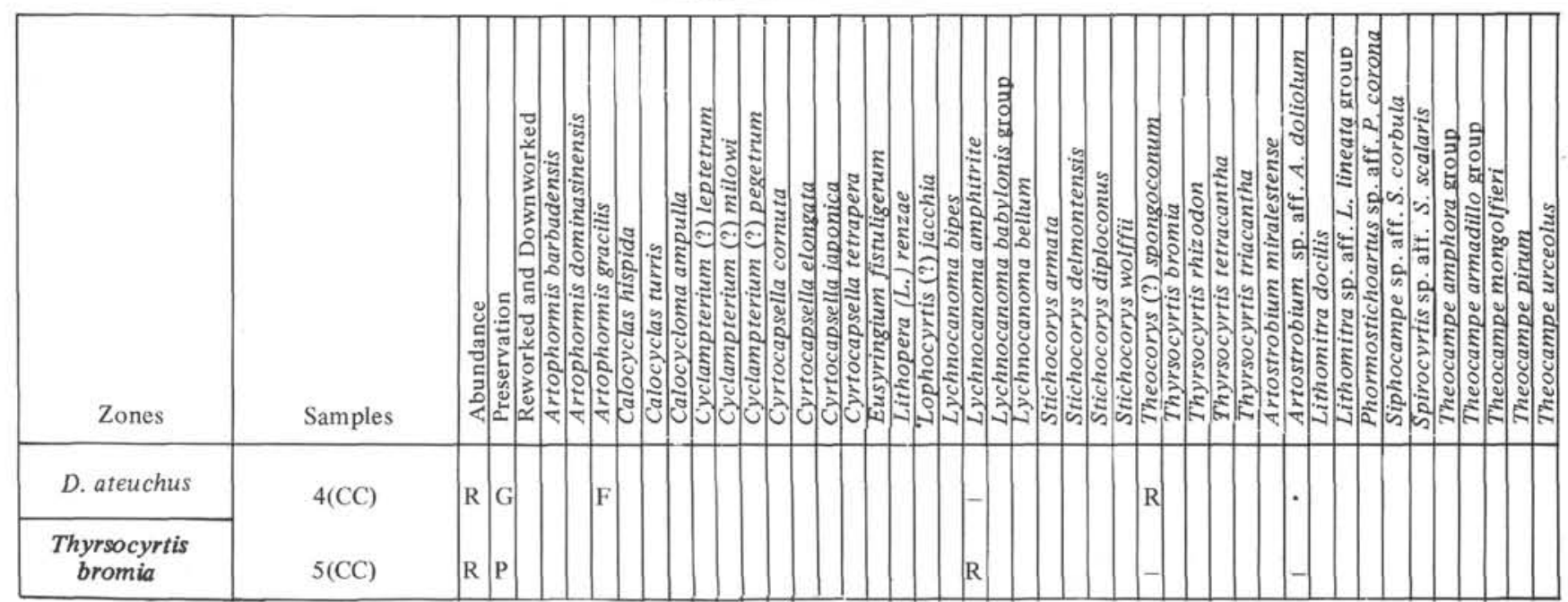

The first and last appearances of all the species and species groups mentioned as present in the taxonomic section have been determined in the list of events, with the exception of the following which were not treated in great enough detail: Lithomitra sp. aff. $L$. lineata group; Phormostichoartus sp. aff. P. corona; and Theocotyle (Theocotyle) venezuelensis.

\section{Range Chart, Figure 1}

The list of events for Hole 94 (17-1 to 32, CC), Hole 96 (3-1 to 5, CC), and Hole 86 (7, CC to 8, CC) has provided the basis for constructing the summary range chart. These three holes have sections that do not quite overlap. The unknown intervals between the oldest sample of one hole and the next oldest sample in another hole, and the uncored intervals in each hole are indicated by dashes on the species range lines. The ranges for the species on the range chart are all given as they appear in the list of events for the core sections listed above except for the Lithochytris archaea evolutionary transition to L. vespertilio which is given as it appears in Hole 95 where this event is judged to be more reliable.

Correlation with the foraminiferal and Blow zones is given as it appears in Figure 2 of the chapter on pelagic sediments of the Campeche embankment area by B.W. McNeely in this volume. However, because the correlation between holes based on the foraminifera does not always agree with the correlation based on Radiolaria, there is some question about the relationship of the foraminiferal zones to the radiolarian zones. Because no detailed 
TABLE 4B

Radiolarians from Hole 96

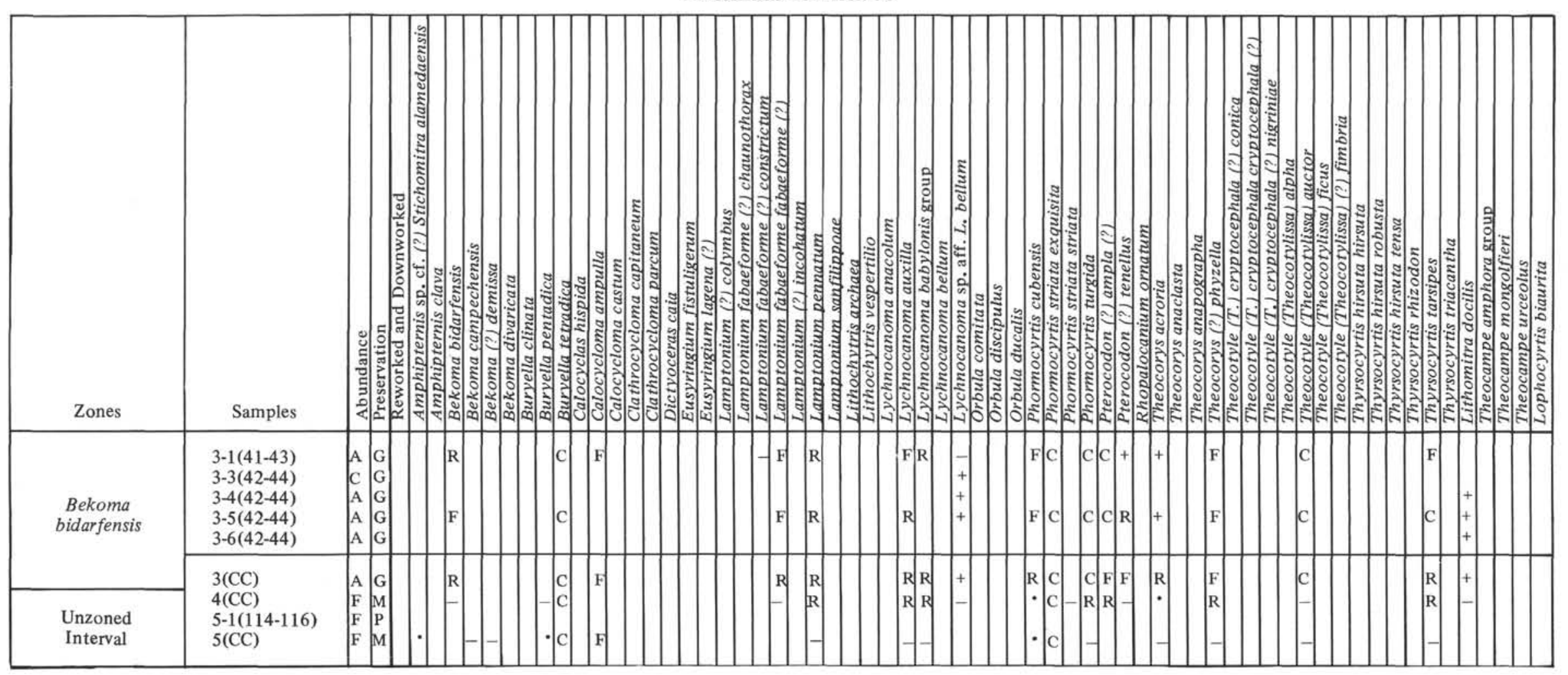


TABLE 6

Radiolarian Events for Holes 86, 94, 95, 96, and 97

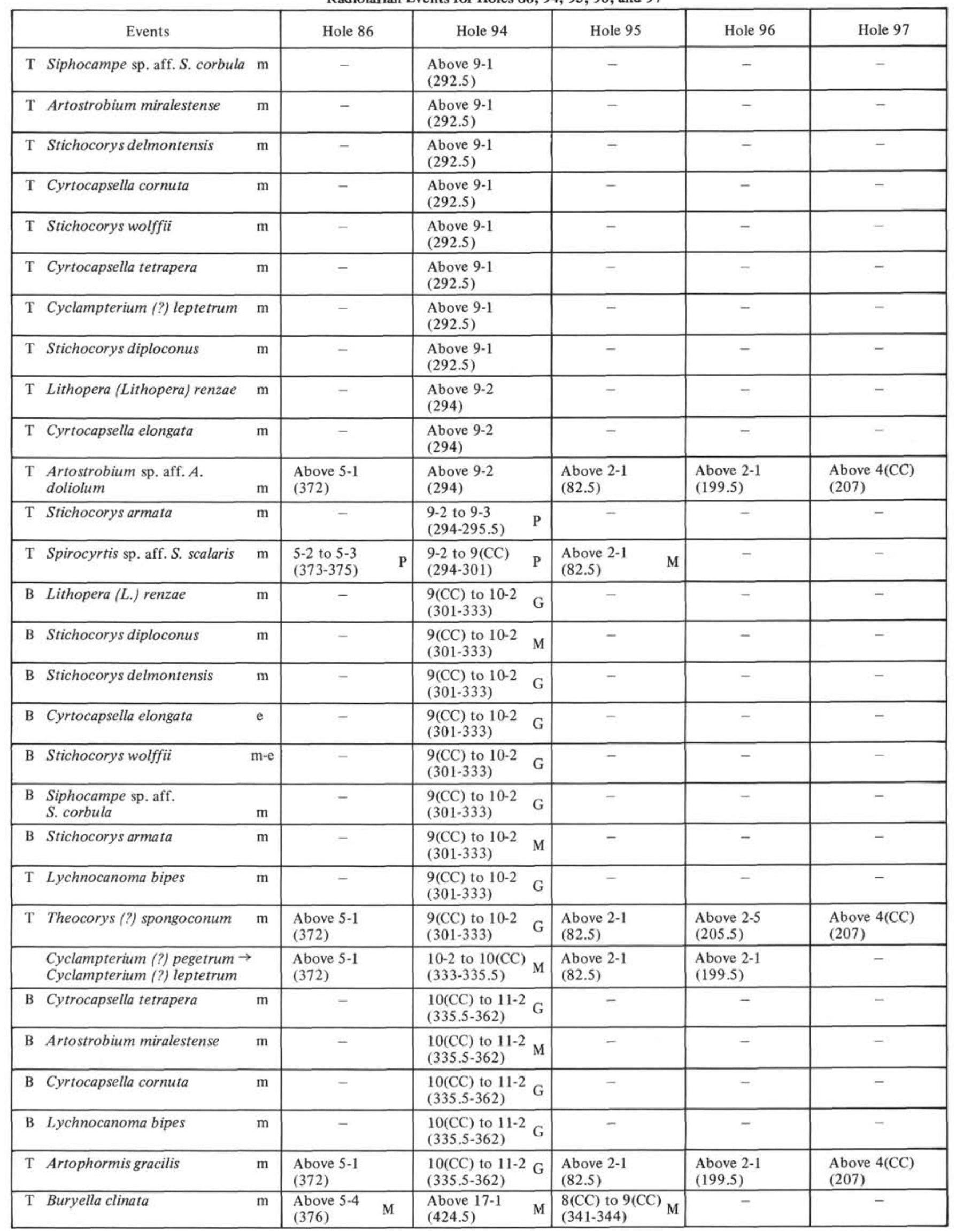


TABLE 6 - Continued

\begin{tabular}{|c|c|c|c|c|c|c|}
\hline Events & & Hole 86 & Hole 94 & Hole 95 & Hole 96 & Hole 97 \\
\hline $\begin{array}{l}\text { Cyclampterium (?) milowi } \rightarrow \\
\text { Cyclampterium (?) pegetrum }\end{array}$ & & $\begin{array}{l}5-3 \text { to } 6(\mathrm{CC}) \quad P \\
(374.5-440)\end{array}$ & $\begin{array}{ll}10(C C) \text { to } & \\
13(C C) & P \\
(335.5-382.5) & \end{array}$ & $\begin{array}{l}4(C C) \text { to } 5-2 \\
(165-200)\end{array}$ & $\begin{array}{l}2(\mathrm{CC}) \text { to } 3-1 \\
(208-301.5)\end{array}$ & - \\
\hline $\mathrm{T}$ Lithomitra docilis & $\mathrm{m}$ & $\begin{array}{l}5(\mathrm{CC}) \text { to } 6(\mathrm{CC}) \mathrm{G} \\
(377-440)\end{array}$ & $\begin{array}{l}11(C C) \text { to } 12-1 \\
(369-369.5)\end{array}$ & $\begin{array}{l}4(C C) \text { to } 5-1 \\
(165-198.5) \quad G\end{array}$ & $\begin{array}{l}2(C C) \text { to } 3-4 \quad G \\
(208-306)\end{array}$ & - \\
\hline $\begin{array}{l}\text { B Artostrobium sp. aff. } \\
\text { A. doliolum }\end{array}$ & $\mathrm{m}$ & 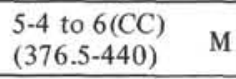 & $\begin{array}{l}11(\mathrm{CC}) \text { to } 12-1 \mathrm{M} \\
(369-369.5)\end{array}$ & $\begin{array}{l}5-2 \text { to } 5-3 \\
(200-201.5)\end{array}$ & $\begin{array}{l}2(\mathrm{CC}) \text { to } 3-1 \\
(208-301.5)\end{array}$ & $\begin{array}{l}\text { Below 4(CC) } \\
(207)\end{array}$ \\
\hline B Spirocyrtis sp. aff.S. scalaris & $\mathrm{m}$ & $\begin{array}{l}\begin{array}{l}5-3 \text { to } 6(\mathrm{CC}) \\
(375-440)\end{array} \quad \mathrm{M} \\
\end{array}$ & $\begin{array}{l}13-3 \text { to } 14-2 \\
(381.5-408) \\
\end{array}$ & $\begin{array}{l}4-4 \text { to } 5-1 \\
(164-198.5)\end{array}$ & - & - \\
\hline B Theocorys (?) spongoconum & $\mathrm{m}$ & $\begin{array}{l}5-2 \text { to } 5-3 \\
(373.5-374.5) \quad M\end{array}$ & $\begin{array}{l}13-3 \text { to } 14-2 \\
(381.5-408) \\
\end{array}$ & $\begin{array}{l}5-2 \text { to } 5-3 \\
(200-201.5)\end{array}$ & $\begin{array}{l}2-5 \text { to } 2-6 \\
(205.5-207) \quad P\end{array}$ & $\begin{array}{l}\text { Below } 4(\mathrm{CC}) \\
(207)\end{array}$ \\
\hline $\mathrm{T}$ Theocampe amphora group & $\mathrm{m}$ & $\begin{array}{l}\begin{array}{l}5-4 \text { to } 6(\mathrm{CC}) \\
(376.5-440)\end{array} \quad \mathrm{G} \\
\end{array}$ & $\begin{array}{l}13-3 \text { to } 14-2 \\
(381.5-408) \\
\end{array}$ & $\begin{array}{l}5-3 \text { to } 5-4 \\
(201.5-203) \\
\end{array}$ & - & - \\
\hline B Cyclampterium (?) milowi & $\mathrm{m}$ & - & $\begin{array}{l}13-3 \text { to } 13(\mathrm{CC}) \mathrm{M} \\
(381.5-382.5)\end{array}$ & $\begin{array}{l}5(\mathrm{CC}) \text { to } 6-1 \\
(204-236.5)\end{array}$ & - & - \\
\hline T Theocampe pirum & $\mathrm{m}$ & $\begin{array}{l}5(\mathrm{CC}) \text { to } 6(\mathrm{CC}) \mathrm{M} \\
(377-440)\end{array}$ & $\begin{array}{l}13-3 \text { to } 14-2 \\
(381.5-408)\end{array} \quad \mathrm{G}$ & $\begin{array}{l}5(\mathrm{CC}) \text { to } 6-1 \\
(204-236.5)\end{array}$ & - & - \\
\hline $\mathrm{T}$ Theocampe urceolus & $\mathrm{m}$ & $\begin{array}{l}5(\mathrm{CC}) \text { to } 6(\mathrm{CC}) \mathrm{G} \\
(377-440)\end{array}$ & $\begin{array}{l}\begin{array}{l}13-3 \text { to } 14-2 \\
(381.5-408)\end{array} \quad \mathrm{G} \\
\end{array}$ & $\begin{array}{l}5(C C) \text { to } 6-1 \\
(204-236.5)\end{array}$ & - & - \\
\hline $\mathrm{T}$ Theocampe armadillo group & $\mathrm{m}$ & $\begin{array}{l}5(\mathrm{CC}) \text { to } 6(\mathrm{CC}) \mathrm{G} \\
(377-440)\end{array}$ & 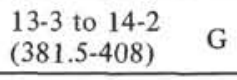 & $\begin{array}{l}\begin{array}{l}5(\mathrm{CC}) \text { to } 6-1 \\
(204-236.5)\end{array} \quad \mathrm{G} \\
\end{array}$ & - & - \\
\hline $\mathrm{T}$ Theocampe mongolfieri & $\mathrm{m}$ & $\begin{array}{l}5(\mathrm{CC}) \text { to } 6(\mathrm{CC}) \mathrm{G} \\
(377-440){ }^{2}\end{array}$ & $\begin{array}{l}13(\mathrm{CC}) \text { to } 14-2 \text { G } \\
(382.5-408)\end{array}$ & $\begin{array}{l}5(\mathrm{CC}) \text { to } 6-1 \\
(204-236.5)\end{array}$ & - & - \\
\hline $\mathrm{T}$ Lophocyrtis (?) jacchia & $\mathrm{m}$ & $\begin{array}{l}5(\mathrm{CC}) \text { to } 6(\mathrm{CC}) \mathrm{G} \\
(377-440)\end{array}$ & $\begin{array}{l}13(\mathrm{CC}) \text { to } 14-2 \mathrm{G} \\
(382.5-408)\end{array}$ & $\begin{array}{l}5(\mathrm{CC}) \text { to } 6-1 \\
(204-236.5)\end{array}$ & - & - \\
\hline $\begin{array}{l}\text { T Lychnocanoma babylonis } \\
\text { group }\end{array}$ & $\mathrm{m}$ & $\begin{array}{l}5(\mathrm{CC}) \text { to } 6(\mathrm{CC}) \mathrm{G} \\
(377-440)\end{array}$ & $\begin{array}{l}13(\mathrm{CC}) \text { to } 14-2 \text { G } \\
(382.5-408)\end{array}$ & $\begin{array}{l}5(\mathrm{CC}) \text { to } 6-1 \\
(204-236.5)\end{array}$ & - & - \\
\hline $\begin{array}{l}\text { Artophormis barbadensis } \rightarrow \\
\text { Artophormis gracilis }\end{array}$ & & - & $\begin{array}{l}13(\mathrm{CC}) \text { to } 14-2 \text { G } \\
(382.5-408)\end{array}$ & $\begin{array}{l}5(\mathrm{CC}) \text { to } 6-1 \\
(204-236.5) \quad \mathrm{P}\end{array}$ & - & $?$ \\
\hline $\mathrm{T}$ Lychnocanoma amphitrite & $\mathrm{m}$ & $\begin{array}{l}5(C C) \text { to } 6(C C) \\
(377-440)\end{array}$ & $\begin{array}{l}13(\mathrm{CC}) \text { to } 14-2 \text { G } \\
(382.5-408)\end{array}$ & $\begin{array}{l}5(C C) \text { to } 6-1 \\
(204-236.5) \quad G\end{array}$ & - & $\begin{array}{l}4(\mathrm{CC}) \text { to } 5(\mathrm{CC}) \mathrm{P} \\
(207-251)\end{array}$ \\
\hline B Artophormis barbadensis & $\mathrm{m}$ & - & $\begin{array}{l}14-3 \text { to } 14-4 \quad M \\
(409.5-411)\end{array}$ & - & - & - \\
\hline $\mathrm{T}$ Calocyclas turris & $\mathrm{m}$ & $\begin{array}{l}5(\mathrm{CC}) \text { to } 6(\mathrm{CC}) \mathrm{G} \\
(377-440)\end{array}$ & $\begin{array}{l}14(\mathrm{CC}) \text { to } 15-4 \mathrm{G} \\
(412-417)\end{array}$ & $\begin{array}{l}5(\mathrm{CC}) \text { to } 6-1 \\
(204-236.5) \\
\end{array}$ & - & - \\
\hline $\mathrm{T}$ Thyrsocyrtis tetracantha & $\mathrm{m}$ & $\begin{array}{l}5(\mathrm{CC}) \text { to } 6(\mathrm{CC}) \mathrm{G} \\
(377-440)\end{array}$ & $\begin{array}{l}14(\mathrm{CC}) \text { to } 15-4 \mathrm{G} \\
(412-417)\end{array}$ & $\begin{array}{l}5(\mathrm{CC}) \text { to } 6-1 \\
(204-236.5) \\
\end{array}$ & - & - \\
\hline $\mathrm{T}$ Thyrsocyrtis bromia & $\mathrm{m}$ & $\begin{array}{l}5(\mathrm{CC}) \text { to } 6(\mathrm{CC}) \mathrm{G} \\
(377-440)\end{array}$ & $\begin{array}{l}14(\mathrm{CC}) \text { to } 15-4 \mathrm{G} \\
(412-417)\end{array}$ & $\begin{array}{l}5(C C) \text { to } 6-1 \\
(204-236.5) \\
\end{array}$ & - & - \\
\hline $\mathrm{T}$ Thyrsocyrtis rhizodon & $\mathrm{m}$ & $\begin{array}{l}5(\mathrm{CC}) \text { to } 6(\mathrm{CC}) \mathrm{G} \\
(377-440)\end{array}$ & $\begin{array}{l}14(\mathrm{CC}) \text { to } 15-4 \mathrm{G} \\
(412-417)\end{array}$ & $\begin{array}{l}5(\mathrm{CC}) \text { to } 6-1 \\
(204-236.5)\end{array}$ & - & - \\
\hline T Calocycloma ampulla & $\mathrm{m}$ & $\begin{array}{l}\begin{array}{l}5-4 \text { to } 6(\mathrm{CC}) \\
(376.5-440)\end{array} \quad \mathrm{M} \\
\end{array}$ & $\begin{array}{l}14(\mathrm{CC}) \text { to } 16-1 \mathrm{M} \\
(412-418.5)\end{array}$ & $\begin{array}{l}5(\mathrm{CC}) \text { to } 6-1 \\
(204-236.5)\end{array}$ & $\begin{array}{l}2(\mathrm{CC}) \text { to } 3-1 \\
(208-301.5)\end{array}$ & - \\
\hline $\mathrm{T}$ Artophormis dominasinensis & $\mathrm{m}$ & - & $\begin{array}{l}\begin{array}{l}16-2 \text { to } 16-3 \\
(420-421.5)\end{array} \quad P \\
\end{array}$ & $\begin{array}{l}5(\mathrm{CC}) \text { to } 6-1 \\
(204-236.5)\end{array}$ & - & - \\
\hline $\begin{array}{l}\text { Thyrsocyrtis triacantha } \rightarrow \\
\text { Thyrsocyrtis tetracantha }\end{array}$ & & $\begin{array}{l}5(\mathrm{CC}) \text { to } 6(\mathrm{CC}) \mathrm{G} \\
(377-440)\end{array}$ & $\begin{array}{l}16-3 \text { to } 16(\mathrm{CC}) \\
(421.5-422.5)\end{array}$ & $\begin{array}{l}5(\mathrm{CC}) \text { to } 6-1 \\
(204-236.5)\end{array}$ & - & - \\
\hline $\mathrm{T}$ Eusyringium fistuligerum & $\mathrm{m}$ & - & $\begin{array}{l}16-2 \text { to } 16-3 \\
(420-421.5)\end{array}$ & $\begin{array}{l}6-1 \text { to } 6-4 \\
(236.5-241) \\
\end{array}$ & - & - \\
\hline B Lophocyrtis (?) jacchia & $\mathrm{m}$ & $\begin{array}{l}6(\mathrm{CC}) \text { to } 7(\mathrm{CC}) \mathrm{G} \\
(440-505.5)\end{array}$ & $\begin{array}{l}16-3 \text { to } 17-1 \\
(421.5-424.5) \quad G\end{array}$ & $\begin{array}{l}6-3 \text { to } 6(C C) \\
(239.5-245) \\
\end{array}$ & - & - \\
\hline B Calocyclas turris & $\mathrm{m}$ & $\begin{array}{l}6(\mathrm{CC}) \text { to } 7(\mathrm{CC}) \mathrm{G} \\
(440-505.5)\end{array}$ & $\begin{array}{l}16(\mathrm{CC}) \text { to } 17-1 \text { G } \\
(422.5-424.5)\end{array}$ & $\begin{array}{l}6(C C) \text { to } 7-1 \\
(245-274.5) \\
\end{array}$ & - & - \\
\hline B Artophormis dominasinensis & $\mathrm{m}$ & - & $\begin{array}{l}16-3 \text { to } 17-1 \\
(421.5-424.5)\end{array}$ & $\begin{array}{l}6(\mathrm{CC}) \text { to } 7-1 \\
(245-274.5) \\
\end{array}$ & - & - \\
\hline B Theocampe pirum & $\mathrm{m}$ & $\begin{array}{l}6(\mathrm{CC}) \text { to } 7(\mathrm{CC}) \mathrm{G} \\
(440-505.5)\end{array}$ & $\begin{array}{l}16(\mathrm{CC}) \text { to } 17-1 \text { G } \\
(422.5-424.5)\end{array}$ & $\begin{array}{l}\text { 6-4 to } 6(\mathrm{CC}) \\
(241-245)\end{array}$ & - & - \\
\hline B Theocampe armadillo group & $\mathrm{m}$ & $\begin{array}{l}6(\mathrm{CC}) \text { to } 7(\mathrm{CC}) \mathrm{G} \\
(440-505.5)\end{array}$ & $\begin{array}{l}16(\mathrm{CC}) \text { to } 17-1 \mathrm{G} \\
(422.5-424.5)\end{array}$ & $\begin{array}{l}6(C C) \text { to } 7-1 \\
(245-274.5) \quad G\end{array}$ & - & - \\
\hline
\end{tabular}


TABLE 6 - Continued)

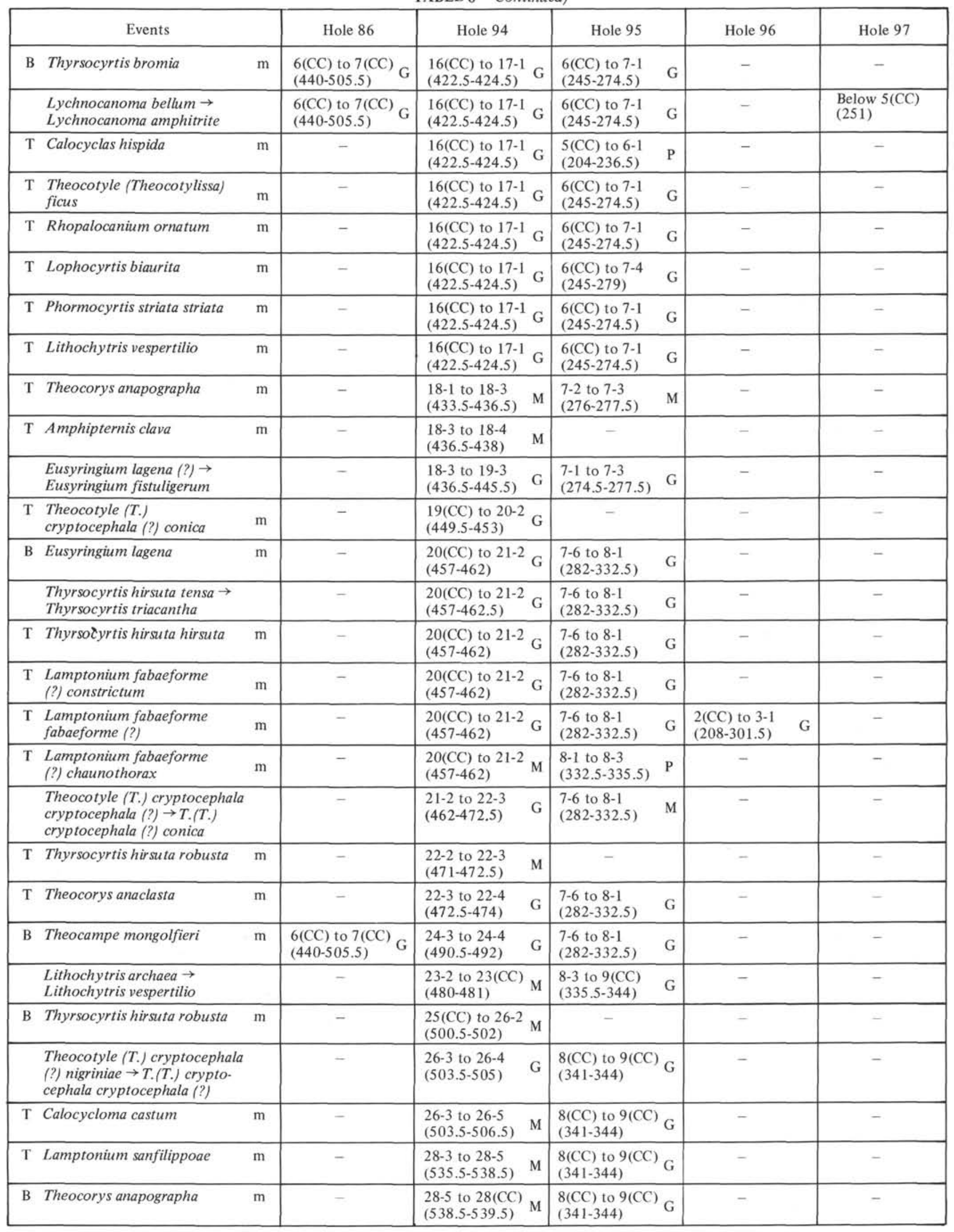


TABLE 6 - Continued

\begin{tabular}{|c|c|c|c|c|c|c|}
\hline Events & & Hole 86 & Hole 94 & Hole 95 & Hole 96 & Hole 97 \\
\hline B Theocorys anaclasta & $\mathrm{m}$ & - & $\begin{array}{l}28-5 \text { to } 28(\mathrm{CC}) \\
(538.5-539.5)\end{array}$ & $\begin{array}{l}8(\mathrm{CC}) \text { to } 9(\mathrm{CC}) \mathrm{G} \\
(341-344)\end{array}$ & - & - \\
\hline B Thyrsocyrtis hirsuta tensa & m-e & - & $\begin{array}{l}28(\mathrm{CC}) \text { to } 29(\mathrm{CC}) \\
(539.5-551) \quad \mathrm{M}\end{array}$ & $\begin{array}{l}8(\mathrm{CC}) \text { to } 9(\mathrm{CC}) \mathrm{G} \\
(341-344)\end{array}$ & - & - \\
\hline B Thyrsocyrtis rhizodon & $\mathrm{m}$ & $\begin{array}{l}6(\mathrm{CC}) \text { to } 7(\mathrm{CC}) \mathrm{G} \\
(440-505.5)\end{array}$ & $\begin{array}{l}28(C C) \text { to } 29(C C) \\
(539.5-551) \quad G\end{array}$ & $\begin{array}{l}8(\mathrm{CC}) \text { to } 9(\mathrm{CC}) \mathrm{G} \\
(341-344)\end{array}$ & - & - \\
\hline B Rhopalocanium ornatum & $\mathrm{m}$ & - & $\begin{array}{l}28(\mathrm{CC}) \text { to } 29(\mathrm{CC}) \\
(539.5-551) \quad \mathrm{G}\end{array}$ & $\begin{array}{l}8(\mathrm{CC}) \text { to } 9(\mathrm{CC}) \mathrm{G} \\
(341-344)\end{array}$ & - & - \\
\hline $\begin{array}{l}\text { Phormocyrtis striata exquisita } \\
\rightarrow P \text {. striata striata }\end{array}$ & & $\begin{array}{l}6(\mathrm{CC}) \text { to } 7(\mathrm{CC}) \mathrm{G} \\
(440-505.5)\end{array}$ & $\begin{array}{l}28(C C) \text { to } 29(C C) \\
(539.5-551) \quad G\end{array}$ & $\begin{array}{l}8(\mathrm{CC}) \text { to } 9(\mathrm{CC}) \mathrm{G} \\
(341-344)\end{array}$ & $\begin{array}{l}2(\mathrm{CC}) \text { to } 3-1 \\
(208-301.5) \quad G\end{array}$ & - \\
\hline $\begin{array}{l}\text { B Lamptonium fabaeforme } \\
\text { (?) constrictum }\end{array}$ & $\mathrm{m}$ & - & $\begin{array}{l}28(\mathrm{CC}) \text { to } 29(\mathrm{CC}) \\
(539.5-551) \quad \mathrm{G}\end{array}$ & $\begin{array}{l}8(\mathrm{CC}) \text { to } 9(\mathrm{CC}) \mathrm{G} \\
(341-344)\end{array}$ & - & - \\
\hline T Theocorys acroria & $\mathrm{m}$ & - & $\begin{array}{l}28(C C) \text { to } 29(C C) \\
(539.5-551) \quad G\end{array}$ & $\begin{array}{l}8(C C) \text { to } 9(C C) G \\
(341-344)\end{array}$ & $\begin{array}{l}2(\mathrm{CC}) \text { to } 3-1 \\
(208-301.5) \quad G\end{array}$ & - \\
\hline B Theocampe amphora group & $\mathrm{m}$ & $\begin{array}{l}6(\mathrm{CC}) \text { to } 7(\mathrm{CC}) \mathrm{G} \\
(440-505.5)\end{array}$ & $\begin{array}{l}28(\mathrm{CC}) \text { to } 29(\mathrm{CC}) \\
(539.5-551) \quad \mathrm{G}\end{array}$ & $\begin{array}{l}\text { Below 9(CC) } \\
(344)\end{array}$ & - & - \\
\hline $\mathrm{T}$ Phormocyrtis cubensis & $\mathrm{m}$ & - & $\begin{array}{l}29(\mathrm{CC}) \text { to } 30-1 \mathrm{G} \\
(551-571.5)\end{array}$ & $\begin{array}{l}\text { Below 9(CC) } \\
(344)\end{array}$ & $\begin{array}{l}2(\mathrm{CC}) \text { to } 3-1 \\
(208-301.5)\end{array}$ & - \\
\hline $\begin{array}{l}\mathrm{T} \text { Theocotyle (Theocotylissa) } \\
\text { (?) fimbria }\end{array}$ & $\mathrm{m}$ & - & $\begin{array}{l}30-1 \text { to } 30-2 \\
(571.5-573.5)\end{array}$ & - & - & - \\
\hline B Amphipternis clava & $\mathrm{m}$ & - & $\begin{array}{l}30-2 \text { to } 30(\mathrm{CC}) \mathrm{P} \\
(573.5-574)\end{array}$ & - & - & - \\
\hline B Lychnocanoma bellum & $\mathrm{m}$ & $\begin{array}{l}6(\mathrm{CC}) \text { to } 7(\mathrm{CC}) \mathrm{G} \\
(440-505.5)\end{array}$ & $\begin{array}{l}30(\mathrm{CC}) \text { to } 31(\mathrm{CC}) \\
(574-589) \quad \mathrm{P}\end{array}$ & $\begin{array}{l}8(\mathrm{CC}) \text { to } 9(\mathrm{CC}) \mathrm{P} \\
(341-344)\end{array}$ & - & - \\
\hline B Calocyclas hispida & $\mathrm{m}$ & - & $\begin{array}{l}30(\mathrm{CC}) \text { to } 31(\mathrm{CC}) \\
(574-589) \quad \mathrm{G}\end{array}$ & $\begin{array}{l}\text { Below 9(CC) } \\
(344)\end{array}$ & - & - \\
\hline $\begin{array}{l}\text { Theocotyle (Theocotylissa) } \\
\text { alpha } \rightarrow T \text {. (Theocotylissa) } \\
\text { ficus }\end{array}$ & & - & $\begin{array}{lr}30(\mathrm{CC}) \text { to } & 31(\mathrm{CC}) \\
(574-589) & \mathrm{M}\end{array}$ & $\begin{array}{l}\text { Below } 9(\mathrm{CC}) \\
(344)\end{array}$ & - & - \\
\hline $\begin{array}{l}\text { Theocotyle (Theocotylissa) } \\
\text { auctor } \rightarrow T \text {. (Theocotylissa) } \\
\text { alpha }\end{array}$ & & - & $\begin{array}{l}30(\mathrm{CC}) \text { to } 31(\mathrm{CC}) \\
(574-589) \quad \mathrm{M}\end{array}$ & $\begin{array}{l}\text { Below } 9(\mathrm{CC}) \\
(344)\end{array}$ & $\begin{array}{l}2(\mathrm{CC}) \text { to } 3-1 \\
(208-301.5)\end{array}$ & - \\
\hline T Pterocodon (?) ampla (?) & $\mathrm{m}$ & - & $\begin{array}{l}30(\mathrm{CC}) \text { to } 31(\mathrm{CC}) \\
(574-589) \quad \mathrm{G}\end{array}$ & - & $\begin{array}{l}2(\mathrm{CC}) \text { to } 3-1 \\
(208-301.5) \quad G\end{array}$ & - \\
\hline $\mathrm{T}$ Pterocodon (?) tenellus & $\mathrm{m}$ & - & $\begin{array}{l}30(\mathrm{CC}) \text { to } 31(\mathrm{CC}) \\
(574-589) \quad \mathrm{G}\end{array}$ & - & $\begin{array}{l}2(\mathrm{CC}) \text { to } 3-1 \\
(208-301.5)\end{array}$ & - \\
\hline $\mathrm{T}$ Theocorys (?) phyzella & $\mathrm{m}$ & - & $\begin{array}{l}30(\mathrm{CC}) \text { to } 31(\mathrm{CC}) \\
(574-589) \quad \mathrm{G}\end{array}$ & & $\begin{array}{l}2(C C) \text { to } 3-1 \\
(208-301.5) \quad G\end{array}$ & - \\
\hline $\mathrm{T}$ Phormocyrtis turgida & $\mathrm{m}$ & - & $\begin{array}{l}30(\mathrm{CC}) \text { to } 31(\mathrm{CC}) \\
(574-589) \quad \mathrm{G}\end{array}$ & - & $\begin{array}{l}2(\mathrm{CC}) \text { to } 3-1 \\
(208-301.5)\end{array}$ & - \\
\hline $\mathrm{T}$ Bekoma bidarfensis & $\mathrm{m}$ & - & $\begin{array}{l}30(\mathrm{CC}) \text { to } 31(\mathrm{CC}) \\
(574-589) \quad \mathrm{G}\end{array}$ & - & $\begin{array}{l}\begin{array}{l}2(\mathrm{CC}) \text { to } 3-1 \\
(208-301.5)\end{array} \\
\end{array}$ & - \\
\hline $\begin{array}{l}\text { Lychnocanoma auxilla } \rightarrow \\
\text { Lithochytris archaea }\end{array}$ & & - & $\begin{array}{l}30(\mathrm{CC}) \text { to } 32(\mathrm{CC}) \\
(574-609) \quad \mathrm{G}\end{array}$ & $\begin{array}{l}\text { Below 9(CC) } \\
(344)\end{array}$ & $\begin{array}{l}2(\mathrm{CC}) \text { to } 3-1 \\
(208-301.5)\end{array}$ & - \\
\hline B Theocampe urceolus & $\mathrm{m}$ & $\begin{array}{l}6(\mathrm{CC}) \text { to } 7(\mathrm{CC}) \mathrm{G} \\
(440-505.5)\end{array}$ & $\begin{array}{l}31(\mathrm{CC}) \text { to } 32(\mathrm{CC}) \\
(589-609) \quad \mathrm{G}\end{array}$ & $\begin{array}{l}\text { Below 9(CC) } \\
(344)\end{array}$ & - & - \\
\hline B Lophocyrtis biaurita & $\mathrm{m}$ & - & $\begin{array}{l}31(\mathrm{CC}) \text { to } 32(\mathrm{CC}) \\
(589-609) \quad \mathrm{G}\end{array}$ & $\begin{array}{l}\text { 8-5 to } 8(\mathrm{CC}) \\
(338.5-341)\end{array}$ & - & - \\
\hline $\begin{array}{l}\text { Thyrsocyrtis tarsipes } \rightarrow \\
\text { T. hirsuta hirsuta }\end{array}$ & & - & $\begin{array}{l}31(\mathrm{CC}) \text { to } 32(\mathrm{CC}) \\
(589-609) \quad \mathrm{G}\end{array}$ & $\begin{array}{l}\text { Below } 9(\mathrm{CC}) \\
(344)\end{array}$ & $\begin{array}{l}\begin{array}{l}2(\mathrm{CC}) \text { to } 3-1 \\
(208-301.5)\end{array} \quad \mathrm{G} \\
\end{array}$ & - \\
\hline $\begin{array}{l}\text { Buryella tetradica } \rightarrow \\
\text { Buryella clinata }\end{array}$ & & $\begin{array}{l}\text { 6(CC) to } 7(\mathrm{CC}) \mathrm{G} \\
(440-505.5)\end{array}$ & $\begin{array}{l}31(\mathrm{CC}) \text { to } 32(\mathrm{CC}) \\
(589-609) \quad \mathrm{G}\end{array}$ & $\begin{array}{l}\text { Below 9(CC) } \\
(344)\end{array}$ & $\begin{array}{l}2(\mathrm{CC}) \text { to } 3-1 \\
(208-301.5)\end{array}$ & - \\
\hline $\begin{array}{l}\text { B Theocotyle (Theocotyle) } \\
\text { cryptocephala (?) nigriniae }\end{array}$ & $\mathrm{m}$ & - & $\begin{array}{l}31(\mathrm{CC}) \text { to } 32(\mathrm{CC}) \\
(589-609) \quad \mathrm{G}\end{array}$ & $\begin{array}{l}\text { Below 9(CC) } \\
(344)\end{array}$ & - & - \\
\hline в Calocycloma castum & $\mathrm{m}$ & - & $\begin{array}{l}31(\mathrm{CC}) \text { to } 32(\mathrm{CC}) \\
(589-609) \quad \mathrm{G}\end{array}$ & $\begin{array}{l}\text { Below 9(CC) } \\
(344)\end{array}$ & - & - \\
\hline $\begin{array}{l}\text { B Theocotyle (Theocotylissa) } \\
\text { (?) fimbria }\end{array}$ & $\mathrm{m}$ & - & $\begin{array}{l}31(\mathrm{CC}) \text { to } 32(\mathrm{CC}) \\
(589-609) \quad \mathrm{G}\end{array}$ & - & - & - \\
\hline
\end{tabular}


TABLE 6 - Continued

\begin{tabular}{|c|c|c|c|c|c|c|}
\hline Events & & Hole 86 & Hole 94 & Hole 95 & Hole 96 & Hole 97 \\
\hline B Lamptonium sanfilippoae & $\mathrm{m}$ & - & $\begin{array}{l}31(\mathrm{CC}) \text { to } 32(\mathrm{CC}) \\
(589-609) \quad \mathrm{M} \\
\end{array}$ & $\begin{array}{l}\text { Below 9(CC) } \\
(344)\end{array}$ & - & - \\
\hline $\begin{array}{l}\text { T Lychnocanoma sp. aff. } \\
\text { L. bellum }\end{array}$ & $\mathrm{m}$ & - & $\begin{array}{l}31(\mathrm{CC}) \text { to } 32(\mathrm{CC}) \\
(589-609) \quad \mathrm{M} \\
\end{array}$ & - & $\begin{array}{l}\begin{array}{l}3-1 \text { to } 3-3 \\
(301.5-304.5)\end{array} \\
\end{array}$ & - \\
\hline $\begin{array}{l}\text { B Lamptonium fabaeforme } \\
\text { (?) chaunothorax }\end{array}$ & $\mathrm{m}$ & - & $\begin{array}{l}\text { Below 32(CC) } \\
(609)\end{array}$ & $\begin{array}{l}\text { Below 9(CC) } \\
(344)\end{array}$ & - & - \\
\hline $\begin{array}{l}\text { Lamptonium pennatum } \rightarrow \\
\text { Lamptonium fabaeforme } \\
\text { fabaeforme (?) }\end{array}$ & & $\begin{array}{l}6(C C) \text { to } 7(C C) \\
(440-505.5)\end{array}$ & $\begin{array}{l}\text { Below 32(CC) } \\
(609)\end{array}$ & - & $\begin{array}{l}3-5 \text { to } 4(\mathrm{CC}) \\
(307.5-321)\end{array} \quad \mathrm{G}$ & - \\
\hline $\begin{array}{l}\text { B Theocotyle (Theocotylissa) } \\
\text { auctor }\end{array}$ & $\mathrm{m}$ & - & $\begin{array}{l}\text { Below 32(CC) } \\
(609)\end{array}$ & - & $\begin{array}{l}3(\mathrm{CC}) \text { to } 4(\mathrm{CC}) \mathrm{M} \\
(310-321)\end{array}$ & - \\
\hline B Pterocodon (?) tenellus & $\mathrm{m}$ & - & $\begin{array}{l}\text { Below 32(CC) } \\
(609)\end{array}$ & - & $\begin{array}{l}3(\mathrm{CC}) \text { to } 4(\mathrm{CC}) \mathrm{M} \\
(310-321)\end{array}$ & - \\
\hline B Bekoma bidarfensis & $\mathrm{m}$ & - & $\begin{array}{l}\text { Below 32(CC) } \\
(609)\end{array}$ & - & $\begin{array}{l}3(\mathrm{CC}) \text { to } 4(\mathrm{CC}) \mathrm{M} \\
(310-321)\end{array}$ & - \\
\hline $\begin{array}{l}\text { B Lychnocanoma sp. aff. } \\
\text { L. bellum }\end{array}$ & $\mathrm{m}$ & - & $\begin{array}{l}\text { Below 32(CC) } \\
(609)\end{array}$ & - & $\begin{array}{l}3(\mathrm{CC}) \text { to } 4(\mathrm{CC}) \mathrm{M} \\
(310-321)\end{array}$ & - \\
\hline $\begin{array}{l}\text { B Lychnocanoma babylonis } \\
\text { group }\end{array}$ & $\mathrm{m}$ & $\begin{array}{l}6(\mathrm{CC}) \text { to } 7(\mathrm{CC}) \mathrm{G} \\
(440-505.5)\end{array}$ & $\begin{array}{l}\text { Below 32(CC) M } \\
(609)\end{array}$ & $\begin{array}{l}\text { Below 9(CC) } \\
(344)\end{array}$ & $\begin{array}{l}4(\mathrm{CC}) \text { to } 5(\mathrm{CC}) \mathrm{P} \\
(321-330.5)\end{array}$ & - \\
\hline B Theocorys acroria & $\mathrm{m}$ & - & $\begin{array}{l}\text { Below 32(CC) } \\
(609)\end{array}$ & - & $\begin{array}{l}4(\mathrm{CC}) \text { to } 5(\mathrm{CC}) \mathrm{P} \\
(321-330.5)\end{array}$ & - \\
\hline B Theocorys (?) phyzella & $\mathrm{m}$ & - & $\begin{array}{l}\text { Below 32(CC) } \\
(609)\end{array}$ & - & $\begin{array}{l}4(\mathrm{CC}) \text { to } 5(\mathrm{CC}) \mathrm{P} \\
(321-330.5)\end{array}$ & - \\
\hline B Pterocodon (?) ampla & $\mathrm{m}$ & - & $\begin{array}{l}\text { Below 32(CC) } \\
(609)\end{array}$ & - & $\begin{array}{l}4(\mathrm{CC}) \text { to } 5(\mathrm{CC}) \mathrm{P} \\
(321-330.5)\end{array}$ & - \\
\hline B Phormocyrtis turgida & $\mathrm{m}$ & - & $\begin{array}{l}\text { Below 32(CC) } \\
(609)\end{array}$ & - & $\begin{array}{l}4(\mathrm{CC}) \text { to } 5(\mathrm{CC}) \mathrm{P} \\
(321-330.5)\end{array}$ & - \\
\hline B Lychnocanoma auxilla & $\mathrm{m}$ & - & $\begin{array}{l}\text { Below 32(CC) } \\
(609)\end{array}$ & - & $\begin{array}{l}4(\mathrm{CC}) \text { to } 5(\mathrm{CC}) \mathrm{P} \\
(321-330.5)\end{array}$ & - \\
\hline B Thyrsocyrtis tarsipes & $\mathrm{m}$ & - & $\begin{array}{l}\text { Below 32(CC) } \\
(609)\end{array}$ & - & $\begin{array}{l}4(\mathrm{CC}) \text { to } 5(\mathrm{CC}) \\
(321-330.5)\end{array}$ & - \\
\hline $\mathrm{T}$ Buryella pentadica & $\mathrm{m}$ & $\begin{array}{l}6(\mathrm{CC}) \text { to } 7(\mathrm{CC}) \mathrm{G} \\
(440-505.5)\end{array}$ & - & - & $\begin{array}{l}4(\mathrm{CC}) \text { to } 5(\mathrm{CC}) \mathrm{P} \\
(321-330.5)\end{array}$ & - \\
\hline $\begin{array}{l}\mathrm{T} \text { Amphipternis sp. cf. ? } \\
\text { Stichomitra alamedaensis }\end{array}$ & $\mathrm{m}$ & $\begin{array}{l}6(\mathrm{CC}) \text { to } 7(\mathrm{CC}) \mathrm{G} \\
(440-505.5)\end{array}$ & - & - & $\begin{array}{l}4(\mathrm{CC}) \text { to } 5(\mathrm{CC}) \\
(321-330.5)\end{array}$ & - \\
\hline B Calocycloma ampulla & $\mathrm{m}$ & - & $\begin{array}{l}\text { Below 32(CC) } \\
(609)\end{array}$ & $\begin{array}{l}\text { Below 9(CC) } \\
(344)\end{array}$ & $\begin{array}{l}\text { Below 5(CC) } \\
(330.5)\end{array}$ & - \\
\hline B Phormocyrtis cubensis & $\mathrm{m}$ & - & $\begin{array}{l}\text { Below 32(CC) } \\
(609)\end{array}$ & - & $\begin{array}{l}\text { Below 5(CC) } \\
(330.5)\end{array}$ & - \\
\hline T Orbula ducalis & $\mathrm{m}$ & $\begin{array}{l}6(\mathrm{CC}) \text { to } 7(\mathrm{CC}) \mathrm{G} \\
(440-505.5)\end{array}$ & - & - & - & - \\
\hline $\mathrm{T}$ Orbula discipulus & $\mathrm{m}$ & $\begin{array}{l}6(\mathrm{CC}) \text { to } 7(\mathrm{CC}) \mathrm{G} \\
(440-505.5)\end{array}$ & - & - & - & - \\
\hline $\mathrm{T}$ Orbula comitata & $\mathrm{m}$ & $\begin{array}{l}6(\mathrm{CC}) \text { to } 7(\mathrm{CC}) \mathrm{G} \\
(440-505.5)\end{array}$ & - & - & - & - \\
\hline T Lamptonium (?) incohatum & $\mathrm{m}$ & $\begin{array}{l}6(\mathrm{CC}) \text { to } 7(\mathrm{CC}) \mathrm{G} \\
(440-505.5)\end{array}$ & - & - & - & - \\
\hline T Lamptonium (?) colymbus & $\mathrm{m}$ & $\begin{array}{l}6(\mathrm{CC}) \text { to } 7(\mathrm{CC}) \mathrm{G} \\
(440-505.5)\end{array}$ & - & - & - & - \\
\hline $\mathrm{T}$ Lychnocanoma anacolum & $\mathrm{m}$ & $\begin{array}{l}6(C C) \text { to } 7(C C) \\
(440-505.5)\end{array}$ & - & - & - & - \\
\hline $\mathrm{T}$ Dictyoceras caia & $\mathrm{m}$ & $\begin{array}{l}6(\mathrm{CC}) \text { to } 7(\mathrm{CC}) \mathrm{G} \\
(440-505.5)\end{array}$ & - & - & - & - \\
\hline T Clathrocycloma parcum & $\mathrm{m}$ & $\begin{array}{l}6(\mathrm{CC}) \text { to } 7(\mathrm{CC}) \mathrm{G} \\
(440-505.5)\end{array}$ & - & - & - & - \\
\hline T Clathrocycloma capitaneum & $\mathrm{m}$ & $\begin{array}{l}6(\mathrm{CC}) \text { to } 7(\mathrm{CC}) \mathrm{G} \\
(440-505.5)\end{array}$ & - & - & - & - \\
\hline $\mathrm{T}$ Bekoma divaricata & $\mathrm{m}$ & $\begin{array}{l}6(C C) \text { to } 7(C C) \\
(440-505.5)\end{array}$ & - & - & - & - \\
\hline
\end{tabular}


TABLE 6 - Continued

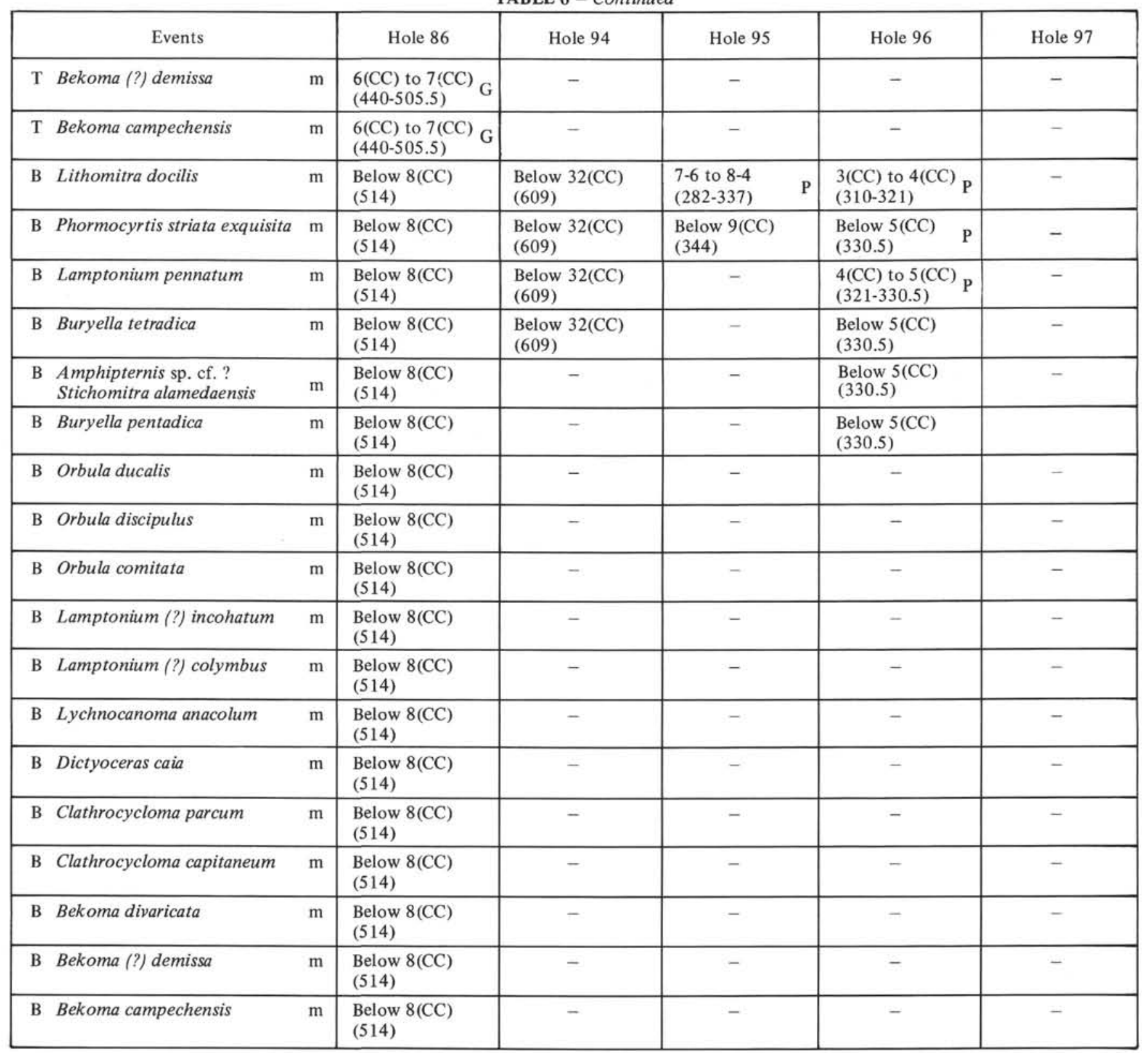

information on foraminiferal ranges is available, no judgement can be made as to which hole should be used for correlation of radiolarian and foraminiferal zones. Therefore the foraminiferal zone assignments for the specific cores forming the vertical scale of the range chart have been used.

The following species are present in Core 86-8, the lowest core section on the range chart, and may extend downward: Amphipternis sp. cf. ? Stichomitra alamedaensis; Bekoma campechensis; B. (?) demissa; B. divaricata; Buryella pentadica; $B$. tetradica; Clathrocycloma capitaneum; C. parcum; Dictyoceras caia; Lychnocanoma anacolum; Lamptonium pennatum; L. (?) colymbus; L. (?) incohatum; Lithomitra docilis; Orbula comitata; $O$. discipulus; $O$. ducalis; and Phormocyrtis striata exquisita.

All the species on the range chart which extend upward into younger strata have been tabulated and their upper limits are given in the list of events. An exception is $\mathrm{Bu}$ ryella clinata which occurs sporadically as an isolated specimen into the late Oligocene and whose upper limit is not known certainly. Species whose upper limits fall in the interval represented by the hiatus between sections 94-17 and 94-16 are: Calocyclas hispida; Lithochytris vespertilio; Lophocyrtis biaurita; Phormocyrtis striata striata; Rhopalocanium ornatum; and Theocotyle (Theocotylissa) ficus. 


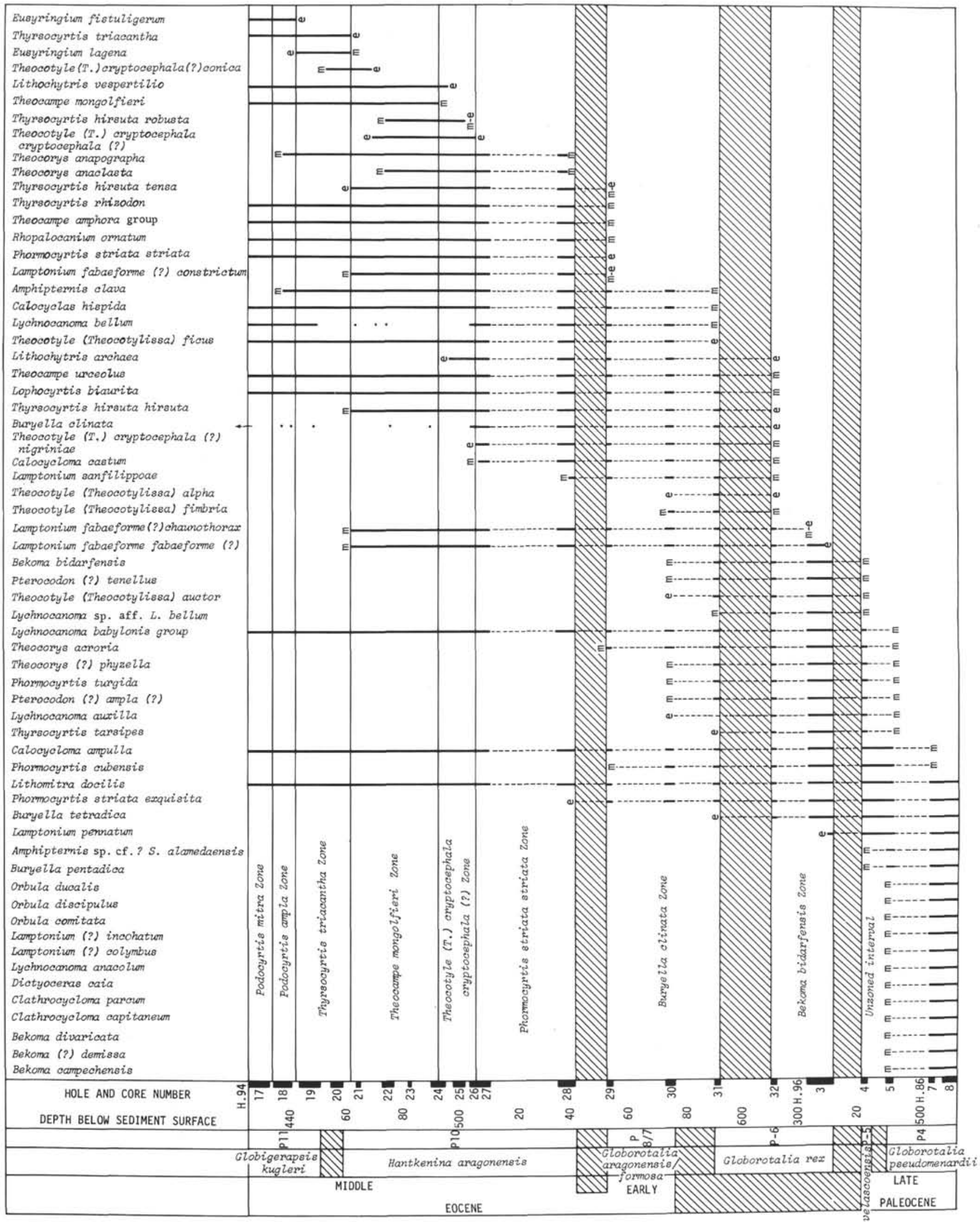

Figure 1. Range chart. 


\section{Correlation Chart, Figure 2}

Besides providing the basis for the range chart (Figure 1), the list of events provides the basis for constructing the correlation chart (Figure 2, fold out at back of book). Because of space limitations not all of the events could be recorded on the correlation chart, and species names have necessarily been abbreviated. Complete names may be found in the taxonomic section. The abbreviations used are the same as those explained for the list of events with the exception that reliability is indicated by the type of line - solid for good, dashed for moderate, and dash-dotted for poor.

The correlation between holes that has resulted from this work with the Amphipyndacidae, Artostrobiidae, and Theoperidae is in agreement with the correlations based on the other radiolarian families by Sanfilippo and Riedel in another chapter of this volume.

The extent of the agreement with the calcareous microfossils is shown in Figure 3.

\section{Radiolarian Zonation and Table 7}

Four new radiolarian zones have been defined. They encompass the interval from the late Late Paleocene to the early Middle Eocene. These four new zones are described below, listed in order from the oldest to the youngest. Some of the events in each zone will be for species other than those belonging to the families treated here. These species are described in a separate chapter by Sanfilippo and Riedel in this volume.

Bekoma bidarfensis Zone. The base is defined by the earliest morphotypic appearance of Bekoma bidarfensis which may be approximately synchronous with the earliest morphotypic appearance of Theocotyle (Theocotylissa) auctor.

Events included in this zone are:

The transition from Lamptonium pennatum to Lamptonium fabaeforme fabaeforme(?).

The latest occurrences of Stylotrochus alveatus and Stylosphaera goruna.

The earliest morphotypic-evolutionary appearance of Lamptonium fabaeforme (?) chaunothorax.

Buryella clinata Zone. The base is defined by the earliest evolutionary appearance of Buryella clinata which may be approximately synchronous with the earliest morphotypic appearance of Lamptonium sanfilippoae, Theocotyle (Theocotyle) cryptocephala (?) nigriniae, Theocampe urceolus, Dictyospyris melissium. D. gigas, Dendrospyris acuta, Thecosphaerella glebulenta, and Spongomelissa cucumella; and the transition from Thyrsocyrtis tarsipes to Thyrsocyrtis hirsuta hirsuta.

Events included in this zone are:

The last morphotypic appearance of Pterocodon (?) ampla (?), Phormocyrtis turgida, Theocorys (?) phyzella, Pterocodon (?) tenellus, Bekoma bidarfensis, Thecosphaera larnacium, Thecosphaerella glebulenta, and Giraffospyris lata.

The transition from Theocotyle (Theocotylissa alpha to Theoctyle (Theocotylissa) ficus, from Spongomelissa adunca to $S$. euparyphus, from Spongatractus balbis to $S$. pachystylus, and from Rhabdolithis ellida to $R$. pipa.

The first morphotypic appearance of Periphaena decora, Giraffospyris cyrillium, Ceratospyris articulata, Lithelius hexaxyphophorus, Lithocyclia ocellus group, Dendrospyris turriturcica turriturcica, and Lychnocanoma bellum.

Phormocyrtis striata striata Zone. The base is defined by the earliest evolutionary appearance of Phormocyrtis striata striata which may be approximately synchronous with the morphotypic-evolutionary appearance or Lamptonium fabaeforme (?) constrictum, Thyrsocyrtis hirsuta tensa, Stylosphaera coronata sabaca, Spongodiscus phrix, Podocyrtis diamesa; the earliest morphotypic appearance of Rhopalocanium ornatum, and Podocyrtis platypus; and the last morphotypic occurrence of Spongodiscus quartus quartus, Dictyospyris melissium, and Spongomelissa cucumella.

Events included in this zone are:

The last morphotypic occurrence of Lamptonium sanfilippoae and Dendrospyris turriturcica dasyotus.

The first morphotypic appearance of Periphaena delta, Theocorys anapographa, and Theocorys anaclasta.

The last morphotypic occurrence of Calocycloma castum.

Theocotyle (Theocotyle) cryptocephala cryptocephala (?) Zone. The base is defined by the earliest evolutionary appearance of Theocotyle (Theocotyle) cryptocephala cryptocephala (?).

Events included in the zone are:

The earliest morphotypic-evolutionary appearance of Thyrsocyrtis hirsuta robusta and Lithapium plegmacantha; and the earliest evolutionary appearance of Podocyrtis sinuosa.

The entire range of Stylotrochus quadribrachiatus multibrachiatus.

The last morphotypic occurrence of Stylosphaera coronata sabaca and Dendrospyris turriturcica turriturcica.

The top is defined by the earliest morphotypic appearance of Theocampe mongolfieri.

Table 7 lists all the radiolarian zones from the youngest, Calocycletta costata Zone, to the oldest, Bekoma bidarfensis Zone. Each zone is defined by the pair of core sections between which the base occurs, and the top is coincident with the base of the next higher zone. Because coring was in general intermittent, not all the zones listed are represented in the sediments that were recovered. Zones represented in Leg 10 are: Calocycletta costata Zone, Calocycletta virginis Zone, Dorcadospyirs ateuchus Zone, Theocyrtis tuberosa Zone, Thyrsocyrtis bromia Zone, Podocyrtis mitra Zone, Podocyrtis ampla Zone, Podocyrtis triacantha Zone, Theocampe mongolfieri Zone, Theocotyle (T.) cyrptocephala cryptocephala (?) Zone, Phormocyrtis striata striata Zone, Buryella clinata Zone, and Bekoma bidarfensis Zone.

The Thrysocyrtis tetracantha Zone was not recognized in Leg 10 material. In Holes 86, 94, and 95 the evolutionary transition from Thyrsocyrtis triacantha to $T$. tetracantha, defined as the base of the $T$. tetracantha Zone, appears to fall within the Thyrsocyrtis bromia Zone. 


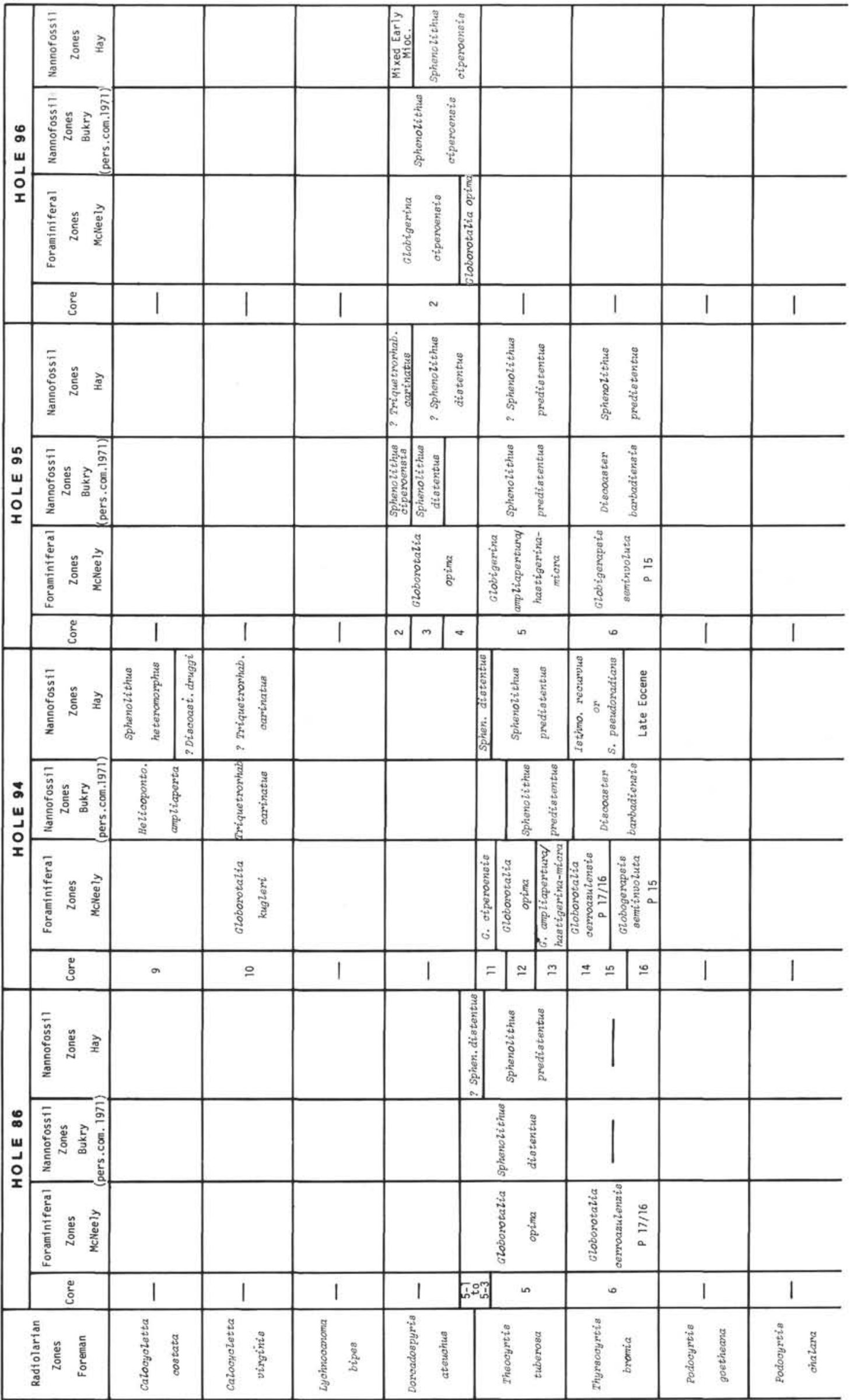

Figure 3. Zonation of Leg 10 cores on the basis of radiolarians, foraminifera, and nannofossils. 


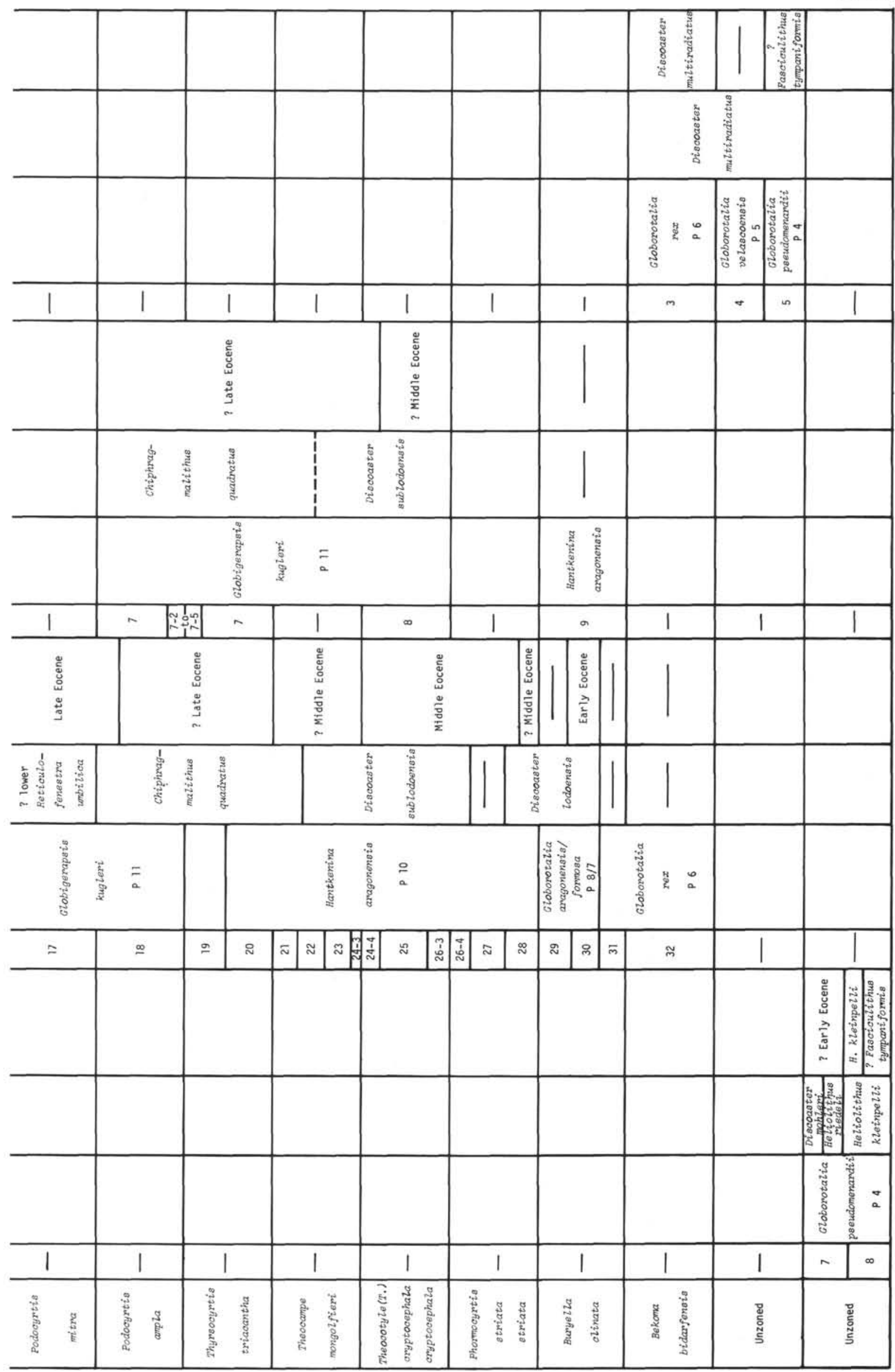

Figure 3. (Continued). 
TABLE 7

Bases of Radiolarian Zones for Holes 86, 94, 95, 96, and 97

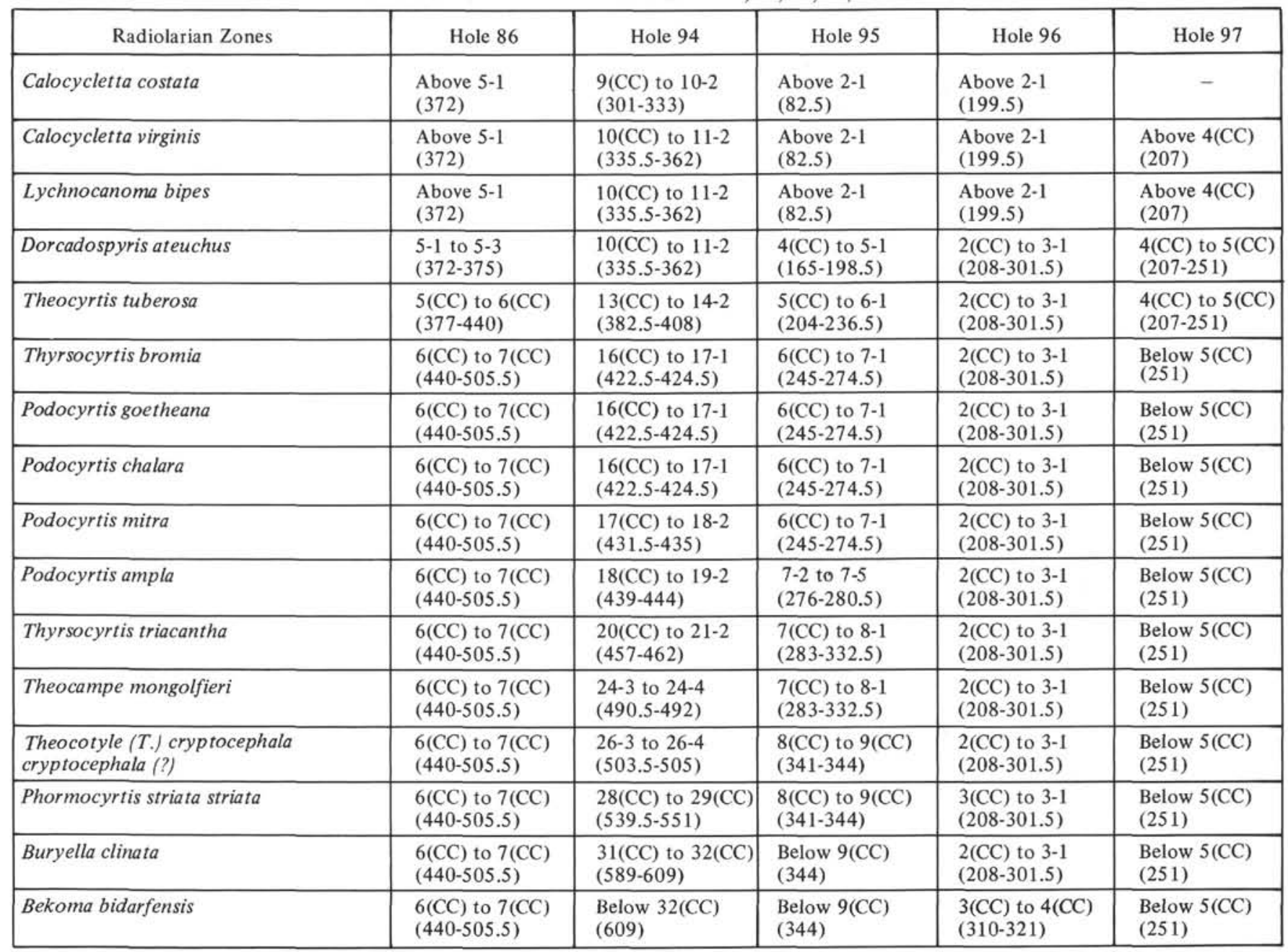

\section{NEW INFORMATION ON PHYLOGENY}

Only new lineages and those lineages previously determined in earlier reports of the Deep Sea Drilling Project to which new information has been added are listed here. Six new lineages are determined and four previously described lineages are extended or amplified.

1) Lamptonium pennatum-Lamptonium fabaeforme (?) constrictum. This lineage consists of four species, the intermediate forms being $L$. fabaeforme fabaeforme (?) and $L$. fabaeforme (?) chaunothorax. The last two forms, L. fabaeforme (?) chaunothorax and L. fabaeforme (?) constrictum, branch off from $L$. fabaeforme fabaeforme (?), and the three cooccur well into the Middle Eocene. The origin of this lineage is not known and it apparently ends with the last appearence of these three forms. The lineage connecting $L$. fabaeforme fabaeforme (?) and $L$. fabaeforme (?) constrictum was determined by Riedel and Sanfilippo (1970, p.537).

2) Bekoma campechensis-Bekoma bidarfensis. This lineage consists of two species only. Its origin is not known and it apparently ends with the latter form.
3) Buryella pentadica-Buryella clinata. This lineage consists of three species, the intermediate form being $B$. tetradica. Its origin is not known and it apparently ends with B. clinata.

4) Thyrsocyrtis tarsipes-Thyrsocyrtis tetracantha. This lineage consists of six species. It originates with $T$. tarsipes, from which $T$. hirsuta hirsuta arises. A branch from the $T$. hirsuta hirsuta line begins with $T$. hirsuta tensa from which $T$. triacantha and T. tetracantha arise. A second branch from $T$. hirsuta hirsuta consists of $T$. hirsute robusta only. The lineage connecting $T$. triacantha and $T$. tetracantha was determined by Riedel and Sanfilippo (1970, p.537).

5) Theocotyle (Theocotylissa) auctor-Theocotyle (Theocotylissa) ficus. This lineage consists of three species, the intermediate form being Theocotyle (Theocotylissa) alpha. Its origin is not known and it apparently ends with Theocotyle (Theocotylissa) ficus.

6) It seems likely that Theocotyle (Theocotylissa) auctor gave rise, not only to the lineage described above, but also to the Theocotyle (Theocotyle) cryptocephale (?) nigriniae -Theocotyle (T.) cryptocephala (?) conica lineage. How- 
ever the relationship, if any, of Theocotyle (Theocotylissa) auctor and Theocotyle (Theocotyle) cryptocephala (?) nigriniae is not yet clearly understood. The Theocotyle (T.) cryptocephala (?) nigriniae-Theocotyle (T.) cryptocephala (?) conica lineage consists of three species, the intermediate species being Theocotyle (T.) cryptocephala cryptocephala (?). That part of the lineage comprising the first two species was noted by Riedel and Sanfilippo (1970, p.537).

7) Theocorys acroria-Theocorys anapographa. This lineage consists of these two species only. A possible second branch may have developed from $T$. acroria to $T$. anaclasta, Its origin is not known.

8) Lychnocanoma sp. aff. L. bellum-Lychnocanoma amphitrite. This lineage consists of three species, the intermediate form being Lychnocanoma bellum. Its origin is not known and it apparently ends with Lychnocanoma amphitrite.

9) Lychnocanoma auxilia-Lithochytris vespertilio. This lineage consists of three species, the intermediate form being Lityochytris archaea. Lychnocanoma auxilla probably arose from a species in the Lychnocanoma babylonis group. The lineage connecting the two younger species was established by Riedel and Sanfilippo (1970, p.537).

10) Phormocyrtis striata exquisita-Phormocyrtis striata striata. This lineage consists of these two species only. Its origin is not known and it apparently ends with the younger form.

\section{SYSTEMATIC SECTION}

\section{Cretaceous Radiolaria}

Cretaceous Radiolaria are treated very briefly with synonymies and some illustrations. The synonymies give the first reference, the reference giving the name by which the species is now known, and references to occurrences of the species in available Initial Reports of the Deep Sea Drilling Project.

Only two cores, one each in Holes 95 and 97, contained Cretaceous Radiolaria. Both are poorly preserved, the sample from Hole 95 somewhat better than that from Hole 97 which had Radiolaria with silica partly replaced with calcareous material.

\section{Hole 95}

Sample $95-13(C C)$ at 400 meters below the sediment surface. Radiolaria are common but, because of poor preservation, identification of many forms beyond the family level was not possible.

\section{Suborder SPUMELLARIA Ehrenberg, 1875}

Family ACTINOMMIDAE Haeckel, 1862, emend. Riedel, 1967b Genus SPONGOPRUNUM Haeckel

Spongoprunum Haeckel, 1887, p. 387.

\section{Spongoprunum sp.}

Spongoprunum sp. Foreman, 1971, pl. 1, fig. B.

$$
\text { Gen. and sp. indet. }
$$$$
\text { (Plate 13, Figure 13) }
$$

Remarks: This spherical form has ridges on its surface forming polygonal frames which enclose numerous, very small, closely and irregularly spaced pores. This form differs from a similar one (Foreman, 1971, p1. 5, fig. 1) of probable Turonian-Cenomanian age in its larger size and numerous, more closely spaced pores.

\section{Gen. and sp. indet.}

(Plate 13, Figure 11)

Actinommid, gen. and sp. indet. Foreman, 1971, pl. 1, fig. 3.
Family SPONGODISCIDAE Haeckel, 1862, emend. Riedel, 1967b

Gen. and sp. indet.

(Plate 13, Figure 15)

Remarks: This large discoidal form has numerous small, circular pores overall and is apparently without spines.

Gen. and sp. indet. cf. Spongodiscus (?) multus Kozlova

(Plate 13, Figure 12)

Spongodiscus (?) multus Kozlova, in Kozlova and Gorbovetz, 1966, p. 87 , pl. 4 , fig. 10 .

Gen. and sp. indet. cf. Spongodiscus multus Kozlova, Kling 1971, p1. 6, figs. H-J.

\section{Genus CRUCELLA Pessagno}

Crucella Pessagno, 1971, p. 51.

Crucella sp. cf. Crucella espartoensis Pessagno

(Plate 13, Figure 14)

Crucella espartoensis Pessagno, 1971, p. 54, pl. 18, figs. 1-4.

$$
\text { Crucella sp. }
$$

(Plate 13, Figure 10)

Remarks: This form is distinguished by its arms which are short and have broad, expanded ends from which extend single, bladed spines. It has previously been observed only in the Campanian-Santonian of Cuba (Foreman, 1971).

\section{Family PSEUDOAULOPHACIDAE Riedel, 1967a}

\section{Genus ALIEVIUM Pessagno}

Alievium Pessagno, in press.

\section{Alievium gallowayi (White) \\ (Plate 13, Figure 9)}

Baculogypsina (?) gallowayi White, 1928, p. 305, pl. 41, figs. 9, 10. Pseudoaulophacus gallowayi (White) (?) Riedel and Sanfilippo, 1970, p. 505 , pl. 2, fig. 5.

Alievium gallowayi (White) Pessagno, in press, pl. 2, figs. 4-6; pl. 3, fig. 5.

Pseudoaulophacus superbus (Squinabol) Kling, 1971, pl. 6, figs. M, N; Foreman, 1971, pl. 2, fig. 5 .

\section{Genus PSEUDOAULOPHACUS Pessagno}

Pseudoaulophacus Pessagno, 1963, p. 200.

\section{Pseudoaulophacus floresensis Pessagno} (Plate 13, Figure 8)

Pseudoaulophacus floresensis Pessagno, 1963, p. 200, pl. 2, figs. 2, 5; pl. 4, fig. 6; pl. 7, figs. 1, 5; Foreman, 1971, pl. 2, fig. 6.

Pseudoaulophacus pargueraensis Pessagno

Pseudoaulophacus pargueraensis Pessagno, 1963, p. 204, pl. 2, figs. 4, 7; pl. 6, figs. 4, 5; Foreman, 1971, pl. 2, fig. 7.

\section{Suborder NASSELLARIA Ehrenberg, 1875}

Family THEOPERIDAE Haeckel, emend. Riedel

Thoeperidae Haeckel, 1881, p. 436, emend. Riedel, 1967b, p. 296.

$$
\text { Genus GONGYLOTHORAX Foreman }
$$

Gongylothorax Foreman, 1968, p. 19.

\section{Gongylothorax verbeeki Tan Sin Hok (Plate 13, Figure 4)}

Dicolocapsa verbeeki Tan Sin Hok, 1927, p. 44, pl. 8, figs. 40, 41. Gongylothorax verbeeki (Tan Sin Hok) Foreman, 1968, p. 20, pl. 2, fig. 8; Kling, 1971, pl. 7, fig. N.

Gen. and sp. indet. (Plate 13, Figure 3)

Theoperid, gen. and sp. indet. Foreman, 1971, pl. 3, fig. 2. 
Gen. and sp. indet.

(Plate 13, Figure 1)

Theoperid, gen. and sp. indet. Kling, 1971, pl. 8, figs. G, H; Foreman, 1971, pl. 3, fig. 3 .

\section{Genus DICTYOMITRA Zittel}

Dictyomitra Zittel, 1876, p. 77.

\section{Dictyomitra torquata Foreman}

(Plate 13, Figure 7)

Dictyomitra torquata Foreman, 1971, pl. 3, fig. 4.

Dictyomitra (Dictyomitra) multicostata Zittel, Pessagno, 1963, p. 206, pl. 1 , fig. 10; pl. 4, figs. 1,3 ; pl. 5 , fig. 7.

Dictyomitra sp. Riedel and Sanfilippo, 1970, pl. 3, fig. 8.

Dictyomitra sp. Kling, 1971, pl. 8, figs. A, D, and [?]B.

\section{Dictyomitra sp. \\ (Plate 13, Figure 6)}

Dictyomitra sp. Foreman, 1971, pl. 3, fig. 5.

\section{Family ARTOSTROBIIDAE Riedel}

Artostrobiidae Riedel, 1967a, p. 149.

\section{Genus ARTOSTROBIUM Haeckel, emend. Foreman}

Artostrobium Haeckel, 1887, p. 1482, emend. Foreman, 1966, p. 355.

\section{Artostrobium urna Foreman}

Artostrobium urna Foreman, 1971, pl. 4, figs. 1, 2.

Artostrobiid, gen. et sp. indet. Riedel and Sanfilippo, 1970, pl. 3, fig. 13; Kling, 1971, pl. 7, fig. 8.

\section{Artostrobium tina Foreman}

Artostrobium tina Foreman, 1971, pl. 4, fig. 3.

Genus THEOCAMPE Haeckel, emend. Burma

Theocampe Haeckel, 1887, p. 1422, emend. Burma, 1959, p. 328.

\section{Theocampe salillum Foreman}

$$
\text { (Plate 13, Figure 2) }
$$

Theocampe salillum Foreman, 1971, pl. 4, fig. 5.

\section{Family AMPHIPYNDACIDAE Riedel}

Amphipyndacidae Riedel, 1967a, p. 148.

$$
\text { Genus AMPHIPYNDAX Foreman }
$$

Amphipyndax Foreman, 1966, p. 355.

\section{Amphipyndax stocki (Campbell and Clark) \\ (Plate 13, Figure 5)}

Stichocapsa (?) stocki Campbell and Clark, 1944b, p. 44, pl. 8, figs. 31-33.

Amphipyndax stocki (Campbell and Clark) Foreman, 1968, p. 78, pl. 8, fig. 12.

Amphipyndax sp. cf. A. stocki (Campbell and Clark) Kling, 1971, pl. 8, fig. L; [?] pl. 8, figs. I, J, K.

Age

Many of the species listed above have been recognized previously from widely separated Santonian-Campanian localities, and a similar assemblage from the mid-Pacific was considered to be SantonianEarly Campanian (probably younger than Early Santonian) in age (Foreman, 1971). On the basis of the cooccurring foraminifera, this assemblage is considered to be Early Campanian.

\section{Hole 97}

Sample $97-11(\mathrm{CC})$ at 333 meters below the sediment surface. A few very poorly preserved Radiolaria with silica partially replaced by calcite were found in one preparation from this sample. Three further preparations yielded no Radiolaria. The assemblage is characterized by long, slender, multisegmented theoperids, numerous large spherical forms, and some indeterminate species of Crucella. A few specimens are illustrated (Plate 13, Figures 16-20).
Age

The assemblage resembles somewhat a fauna described by Aliev (1965) from the Late Albian and Early Cenomanian of northeastern Azerbaidzhan (USSR). As underlying beds $(97-12$, CC) are well dated by foraminifera as Early Cenomanian, a similar age is assigned here.

\section{Tertiary Radiolaria}

Not all of the Radiolaria for which ranges are given on the range chart, or first and last appearances recorded on the list of events, or tabulations given in the tabulation charts are treated in equal detail. Where no additional taxonomic information has been added to a previously described species, it is generally listed only with its original citation and a later one in which a detailed description and/or synonymy has been given. An exception is that all citations of in situ occurrences for species in earlier Initial Reports of the Deep Sea Drilling Project have been listed.

The three families treated here, the Amphipyndacidae, Artostrobiidae, and Theoperidae, are arranged alphabetically. Genera within these families and species within genera are also arranged alphabetically.

\section{Family AMPHIPYNDACIDAE Riedel}

Amphipyndacidae Riedel, 1967a, p. 148.

\section{Genus AMPHIPTERNIS Foreman, new genus}

Definition: Amphipyndacids with transverse, ring-like septum as in Amphipyndax. Collar structures (apical and vertical bars) depend from this septum into thoracic cavity where the primary and secondary lateral bars join the thoracic wall (Figure 7).

Remarks: This genus differs from Amphipyndax in having the collar structures elongated in the thoracic cavity rather than constricted and reduced to form a small chamber. Previously described species belonging to this genus include: Phormocampe alamedaensis Campbell and Clark, $1944 \mathrm{~b}=$ ? Stichomitra alamedaensis (Campbell and Clark) Foreman, 1968, and Lithocampe ? clava Ehrenberg, 1873.

Type species: Lithocampe? clava Ehrenberg, 1873.

Etymology: The name is derived from the Greek amphi (double) and pternis (bottom of a dish) (feminine).

\section{Amphipternis clava (Ehrenberg)}

(Plate 7, Figures 16, 17; Plate 9, Figure 2; Figure 7)

Lithocampe? clava Ehrenberg, 1873, p. 238; 1875, p. 76, pl. 4, fig. 2. Eucyrtidium clava (Ehrenberg) Bütschli, 1882, pl. 30, fig. 22. Lithocampe clava (Ehrenberg) Haeckel, 1887, p. 1507.

Description: Shell club-shaped, of six to perhaps nine segments (usually seven). Surface smooth, with no externally expressed indentation at strictures. Segments increase gradually in length and width until last segment, which is markedly longer and terminates in a single, thorny, sometimes irregularly porous spine or a cluster of short spines. Pores small, circular, approximately equal in size, arranged quincuncially in transverse rows. Proximal segments may have pores less regular and the thorax is occasionally poreless. Distalmost segment with larger pores irregular in shape and arrangement, over entire segment in earlier forms, only distally in later forms.

Measurements (based on twenty-five specimens from 94-30-1 through 94-19-3). Length, exclusive of terminal spine, $165-220 \mu$, of last segment $50-110 \mu$; greatest width $70-100 \mu$.

Remarks: The absence of a terminal spine in the illustrations and descriptions of $L$ ? clava makes certain identification impossible. However, as it is the only form of its kind observed here, and the only form of its kind illustrated and described from material of approximately the same age in Barbados, it seems likely that they are conspecific.

This species is distinguished from Amphipternis sp. cf. ? Stichomitra alamedaensis (Campbell and Clark) by the terminal spine, lack of indentation between segments, and generally heavier shell.

\section{Amphipternis sp. cf. ? Stichomitra alamedaensis (Campbell and Clark)}

(Plate 7, Figure 18; Plate 9, Figure 1)

cf. Phormocampe (Cyrtocorys) alamedaensis Campbell and Clark, 1944b, p. 37 , pl. 7 , fig. 41 .

cf. Phormocampe (Cyrtocorys) alamedaensis var. tenuis Campbell and Clark, 1944b, p. 37, pl. 7, fig. 35, 36. 
cf. ? Stichomitra alamedaensis (Campbell and Clark) Foreman, 1968, p. 77 , pl. 8 ; fig. 4 .

Remarks: Broken forms, with the distalmost segment always missing, occur extremely rarely in samples from $86-8$ (CC) through $96-3-3$. It is not possible to identify them confidently with ? Stichomitra alamedaensis (Campbell and Clark), first described from the Maestrichtian of California and known to extend into the probable Paleocene there (Foreman, 1968). They are illustrated here to indicate that the possibility exists, but their certain identification must await material in which they occur more commonly and are better preserved.

\section{Family ARTOSTROBIIDAE Riedel}

Artostrobiidae Riedel, 1967a, p. 149.

Remarks: Many families of nassellarians including the Artostrobiidae have an enlarged pore or tube associated with the vertical bar or spine of the cephalis. This feature has in the past been ignored or, more recently, described and given a variety of names: lateral tubule (Riedel, 1958); cephalic tubule (Foreman, 1966); cephalic tube (Foreman, 1968); vertical pore (Goll, 1968); cephalopyle (Pessagno, 1969); lateral tube (Riedel and Sanfilippo, 1971).

Of these, the term "vertical pore" of Goll, together with the terms "vertical tube," when it is so developed, appear to be the most simple and clearly self-explanatory terms, and these names are here used for these features. In the material studied the vertical pore or tube could be recognized in many theoperids and acanthodesmiids and in all artostrobiids and botryoids. In the theoperids and artostrobiids it is developed in a variety of ways: (a) as a tube originating on the cephalis or at the collar stricture, with the main external structure apparently cephalic as in the artostrobiids and some species of the genus Clathrocycloma; or as a tube with the main external structure partly cephalic and partly thoracic as in some theoperids with a small cephalis, e.g. the genus Buryella; and (b) as an enlarged pore on the cephalis or collar stricture; or as an enlarged pore immediately below the collar stricture on the proximal thoracic wall.

This structure has been used by Riedel (1967a) as the primary feature distinguishing the family Artostrobiidae, but in view of its occurrence also in other families it seems advisable to emend the definition of the Artostrobiidae as follows:

Radiolarians with six collar pores, a well-developed vertical tube, no appendages, and the pores of at least one major segment arranged in transverse rows. They may have a smooth or ridged surface, and the last segment is not flared.

The quantities indicated for many of the small artostrobiids encountered in Leg 10 samples probably do not reflect their true abundance, as many were undoubtedly lost in preparing samples with a $62 \mu$ sieve.

Genus ARTOSTROBIUM Haeckel

Artostrobium Haeckel, 1887, p. 1482; Foreman, 1966, p. 355.

Artostrobium miralestense (Campbell and Clark)

Dictyocephalus miralestensis Campbell and Clark, 1944b, p. 45, pl. 6, figs. 12-14.

Artostrobium miralestense (Campbell and Clark) Riedel and Sanfilippo, 1971, pl. 1H, figs. 9-17; pl. 2I, figs. 9, 10; pl. 3E, fig. 12.

Artostrobium sp. aff. A. doliolum Riedel and Sanfilippo

Artostrobium doliolum Riedel and Sanfilippo, 1971.

Artostrobium sp. aff. A. doliolum Riedel and Sanfilippo, 1971, pl. 2I, figs. 5-8; pl. 3E, figs. 7-9.

\section{Genus LITHOMITRA Bütschli}

Lithomitra Büschli, 1881, p. 529.

Lithomitra docilis Foreman, new species

(Plate 8, Figures 20-22; Plate 9, Figures 3-5)

Description: Shell of three segments, spindle-shaped. Cephalis subspherical, bearing a large upward-directed vertical tube, and with a few small, circular pores and one large pore dorso-apically; its margin extended to form an upwardly directed apical tube on well-developed specimens. Collar stricture with six collar pores internally, not expressed externally. Thorax subcylindrical, with uniform, small, circular pores irregularly arranged, and distally a single row of pores set in downward directed frames; these frames forming ridges on the indented poreless lumbar stricture. Internally the lumbar stricture marked by a slight thickening of the shell wall and a very narrow septum. Abdomen subcylindrical, expanded medianly, and terminating in a scalloped (broken?) margin. Generally the proximal surface has irregular longitudinal or diagonal ridges between some pores. Pores small, circular, regular, arranged in transverse rows, closely and approximately evenly spaced, except distally where the rows are more widely spaced and the pores are larger, more irregular in size and shape, circular to subquadrangular with the long axis transversely aligned.

Measurements (based on twenty specimens from Cores 86-8 and 96-3). Length overall $110-150 \mu$, of cephalis and thorax $30-40 \mu$, greatest width of abdomen $60-80 \mu$.

Remarks: This is the most persistent form observed. It appears first in the earliest Paleocene samples studied and ranges into the early Oligocene. Late forms tend to have relatively fewer, more widely spaced rows of pores. This species differs from Theocampe dactylica Foreman (1968) in having a medianly expanded, wider abdomen, with rows of pores more closely spaced. It differs from the forms placed by Riedel and Sanfilippo (1971) in the Lithomitra lineata group in having an upward directed tube and differently arranged pores

\section{Lithomitra lineata (Ehrenberg) group}

(Plate 8, Figure 19)

Lithocampe lineata Ehrenberg, 1838, p. 130.

Eucyrtidium lineata (Ehrenberg) Ehrenberg, 1854, pl. 22, fig. 26; pl. 36, fig. $16 \mathrm{C}$.

Lithomitra lineata (Ehrenberg) group Riedel and Sanfilippo, 1971.

Remarks: A great variety of forms has been included in this group by Riedel and Sanfilippo. They report its presence in sediments of Quaternary through late Middle Eocene age. In this material an early form (Plate 8, Figure 19) first present in the Late Paleocene is apparently closely related to specimens illustrated by Riedel and Sanfilippo (1971, pl. 1I and $2 \mathrm{I}$ ). This group has not been tabulated.

Lithomitra sp. aff. Lithomitra lineata (Ehrenberg) group

Lithomitra sp. aff. L. lineata group (Ehrenberg) Riedel and Sanfilippo, 1971.

\section{Genus PHORMOSTICHOARTUS Campbell}

Phormostichoartus Campbell, 1951, p. 530.

Phormostichoartus sp. aff. Phormostichoartus corona (Haeckel)

Cyrtophormis (Acanthocyrtis) corona Haeckel, 1887, p. 1462, pl. 77, fig. 15.

Phormostichoartus sp. aff. P. corona (Haeckel) Riedel and Sanfilippo, 1971, pl. 2J, fig. 6; pl. 3F, figs. 1-5.

Genus SIPHOCAMPE Haeckel

Siphocampe Haeckel, 1881, p. 438.

Siphocampe sp. aff. Siphocampe corbula

Lithocampe corbula Harting, 1863, p.12, pl. 1, fig. 21.

Siphocampe sp. aff. S. corbula (Harting) Riedel and Sanfilippo; 1971, pl. 2I, figs. 11-13.

\section{Genus SPIROCYRTIS Haeckel}

Spirocyrtis Haeckel, 1881, p. 438.

Spirocyrtis sp. aff. Spirocyrtis scalaris Haeckel

Spirocyrtis scalaris Haeckel, 1887, p. 1509, pl. 76, fig. 14.

Spirocyrtis sp. aff. S. scalaris Riedel and Sanfilippo, 1971, pl. 2H, fig. 18; pl. $3 \mathrm{E}$, fig. 2.

\section{Genus THEOCAMPE Haeckel}

Theocampe Haeckel, 1887, p. 1422; Burma, 1959, p. 328.

Theocampe amphora (Haeckel) group

(Plate 8, Figures 7, 9-13; Plate 9, Figures 8, 9)

Dictyocephalus amphora Haeckel, 1887, p. 1305, pl. 62, fig. 4.

Remarks: Included in this group are spindle-shaped forms with pores unequal in size, arranged in relatively closely spaced transverse rows, largest where shell is widest. Surface may be smooth or roughened by individual frames surrounding pores or incomplete longitudinal wavy ridges separating them. The subspherical cephalis bears a horizontally 
directed vertical tube and, in late forms, a second short apical tube. Aperture constricted, with a distinct, smooth, rimmed peristome; transverse section circular.

Not included is a descendant of this group, more elongate in form and with a well-developed apical tube, the abdomen beginning to show some segmental division, and aperture constricted, its termination uneven as though an additional segment had been broken off (Plate 9 , Figure 10). An early form of the T. amphora group is apparently the precursor of Theocampe mongolfieri Ehrenberg. The specimen illustrated by Riedel and Sanfilippo (1971, pl. 3E, fig. 18) as Lithomitra sp. aff. $L$. lineata group apparently belongs here.

\section{Theocampe armadillo (Ehrenberg) group}

Eucyrtidium armadillo Ehrenberg, 1873, p. 225; 1875, p. 70, pl. 9, fig. 10.

Theocampe armadillo (Ehrenberg) group Riedel and Sanfilippo, 1971, pl. 3E, figs. 3-6.

Theocampe mongolfieri (Ehrenberg)

(Plate 8, Figure 6; Plate 9, Figure 17)

Eucyrtidium mongolfiere Ehrenberg, 1854, pl. 36, fig.18, Blower, 1873 , p. 230,1875 , p. 72 , pl. 10 , fig. 3.

Theocampe mongolfieri (Ehrenberg), Burma, 1959, p. 329; Riedel and Sanfilippo, 1970, p. 536, pl. 12, fig. 9; 1971, pl. 3E, fig. 13.

Remarks: Shell as described and illustrated by Riedel and Sanfilippo except that instead of having a smooth even marginal rim late forms have an undulating margin or three short shovel-shaped feet (Plate 9, Figure 17).

\section{Theocampe pirum (Ehrenberg)}

(Plate 9, Figures 11, 12)

Eucyrtidium pirum Ehrenberg, 1873, p. 232; 1875, p. 72, pl. 10, fig. 14. Theocampe pirum (Ehrenberg) Riedel and Sanfilippo, 1971, pl. 3E, figs. 10,11 .

Theocampe urceolus (Haeckel)

(Plate 8, Figures 14-17; Plate 9, Figures 6, 7)

Dictyocephalus urceolus Haeckel, 1887, p. 1305.

(?) Dictyocephalus (Dictyoprora) pulcherrimus Clark and Campbell, 1942 , p. 78 , pl. 8 , figs. $2,3,6,7$.

Description: Shell relatively slender, spindle-shaped, with a subspherical cephalis bearing a horizontally directed vertical tube; late forms sometime with a horn (Plate 9, Figure 7). Collar stricture not well defined externally, with six collar pores internally. Abdomen in early forms slender, slightly inflated medianly, with pores relatively small, approximately equal in size, arranged in evenly and widely spaced regular rows; in later forms tending to be more inflated with relatively larger pores. Surface smooth, or only slightly roughened by downward-directed arches framing pores. Aperture constricted, with smooth even rim; transverse section circular.

Late forms are larger and appear to be transitional to some of the forms included in the Theocampe armadillo group of Riedel and Sanfilippo (1971). The origin of this species is not known.

Measurements (based on twenty specimens from 94-30, CC through 94-16-3). Length, exclusive of horn when present, 125$190 \mu$; greatest width of abdomen $60-85 \mu$.

Remarks: This species differs from members of the Theocampe amphora (Haeckel) group in having pores, approximately equal in size, arranged in widely spaced rows.

\section{Family THEOPERIDAE Haeckel, emend. Riedel}

Theoperidae Haeckel, 1881, Riedel, 1967b, p. 296.

\section{Genus ARTOPHORMIS Haeckel}

Artophormis Haeckel, 1881, p. 438.

Artophormis barbadensis (Ehrenberg)

Calocyclas barbadensis Ehrenberg, 1873, p. 217; 1875, p. 66, pl. 18, fig. 8.

Artophormis barbadensis (Ehrenberg) Haeckel, 1887, p. 1459; Riedel and Sanfilippo, 1970, p. 532, pl. 13, fig. 5; 1971, pl. 3B, figs. 8, 9; Moore, 1971, pl. 5, fig. 9.

\section{Artophormis dominasinensis (Ehrenberg)}

Podocyrtis dominasinensis Ehrenberg, 1873, p. 250; 1875, p. 82, pl. 14, fig. 4.

Artophormis dominasinensis (Ehrenberg) Riedel and Sanfilippo, 1970, p. $532 ; 1971$, pl. 6 , fig. 6 .

\section{Artophormis gracilis Riedel}

Artophormis gracilis Riedel, 1959, p. 300, pl. 2, figs. 12, 13; Riedel and Sanfilippo, 1970, p. 532, pl. 13, figs. 6, 7; 1971, pl. 3B, figs. 5-7; pl. 6, fig. 7; Kling, 1971, pl. 5, fig. G; Moore, 1971, pl. 5, figs. 10, 11.

\section{Genus BEKOMA Riedel and Sanfilippo}

Bekoma Riedel and Sanfilippo, 1971.

Bekoma bidarfensis (Riedel and Sanfilippo)

(Plate 3, Figures 20, 21; Plate 10, Figure 6)

Bekoma bidarfensis Riedel and Sanfilippo, 1971, pl. 7, figs. 1, 2, 5-7 (not $3,4)$.

Remarks: Specimens observed in the Leg 10 material agree well with those described by Riedel and Sanfilippo except that the forms here are smaller (length of cephalis and thorax 125-150 ; greatest width of thorax $130-145 \mu$ ) and forms which have feet branching to form a triangular ring are excluded. No such forms were observed to cooccur with $B$. bidarfensis in the material studied.

This species apparently evolved from Bekoma campechensis by the lateral branches of the feet parting and becoming downwardly directed.

Bekoma campechensis Foreman, new species

(Plate 3, Figure 24; Plate 10, Figures 1, 2; Figure 4)

Description: Shell of two segments with three feet joined by branches which form a triangular ring. Cephalis dome-shaped to rectangular in outline, bearing conical or cylindrical apical and vertical horns. Apex of cephalis flattened, causing the angular appearance when viewed dorsally or ventrally. Cephalis and proximal thorax poreless with a thick hyaline wall, surface roughened with minute irregular papillae, occasionally with tiny spines or nodes apically. Collar stricture not defined externally as contour of cephalis merges with that of thorax. Internally six collar pores, the vertical spine rising very sharply so that the cervical pores tend to be almost in a vertical plane (Figure 4). Thorax proximally narrow, necklike, distally expanded, tending to have straight sides. Expanded portion with pores generally subcircular and subregular in size and arrangement, and surface roughened with small, generally pointed nodes. Fragments of thin lamellar lattice extend below the wide, open aperture. Three sturdy, proximally ridged, straight, divergent feet depend from the shell immediately above the smooth apertural rim. They are joined distally by a triangular ring which is formed by a single inward directed branch of each foot bifurcating and curving slightly downward to join the similar branch of each adjacent foot.

Measurements (based on twenty specimens from Core 86-8). Length of cephalis and thorax together 100-140 $\mu$ (majority $120-135 \mu$ ); width of thorax $105-130 \mu$; length of feet $65-300 \mu$ (generally 120 $200 \mu$ ).

Remarks: $B$. campechensis differs from $B$. divaricata as described under that species.

\section{Bekoma (?) demissa Foreman, new species} (Plate 3, Figure 22; Plate 10, Figure 5; Figure 6)

Description: Cephalis subspherical, apparently partly depressed in the thorax, with small, circular pores overall and bearing two, apical and vertical, slender, rodlike horns which may be ridged basally. Thorax subhemispherical with regularly arranged, uniform, circular pores and surface slightly roughened by small pointed nodes. Thorax inflated between indentations that mark the line of internal ribs from the primary lateral and dorsal bars to the three feet. This inflated thorax partly obscures the collar stricture, which has five collar pores internally, the vertical bar rising so sharply that it does not divide the cervical pore. A smooth rim surrounds the slightly constricted aperture. Three feet, triangular to subtriangular in cross section, extend downward from the distalmost thoracic wall, with very little divergence except distally where they curve outward and terminate in smooth points. The feet may be entirely smooth or have one or two lateral thorns or short branches distally; these have never been observed to join the branches of the adjacent feet. 
Measurements (based on twenty specimens from Core 86-8).

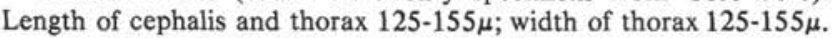

Remarks: This species is distinguished from Bekoma campechensis and $B$. divaricata by the character of the cephalis which differs in having numerous pores overall, has collar structures which differ somewhat (see Figure 6), and appears partly depressed in the thorax, and also by the feet which depend with very little divergence and have less welldeveloped branches. Although this species appears to be related to $B$. campechensis and $B$. divarciata, the considerable difference between its cephalis and that of the type species of Bekoma (Bekoma bidarfensis) makes the generic assignment doubtful.

\section{Bekoma divaricata Foreman, new species} (Plate 3, Figure 23; Plate 10, Figure 3, 4)

Bekoma sp. Riedel and Sanfilippo, 1971, pl. 6, fig. 8.

Description: Shell of two segments with three feet sometimes bearing downwardly directed branches. Cephalis similar to that of Bekoma campechensis. Collar stricture not defined externally, contour of cephalis merging with that of thorax. Thorax proximally poreless, narrow, necklike, its poreless portion shorter than for $B$. campechensis, distally subhemispherical, tending to be almost rectangular in longitudinal section. Subhemispherical portion with subcircular pores which may be uniform in size and arrangement or more irregular. Specimens with uniform pores tend to have a surface with tuberculate nodes and those with more irregular pores a surface with sharper nodes. Fragments of lamellar lattice rarely extend below the wide, open aperture. Three slender, smooth, widely divergent, pointed feet, subtriangular in cross section, depend from the shell immediately above the smooth apertural rim. Distally they generally curve outward. Unlike $B$. campechensis the branches on the distal portion are not uniformly developed and they have never been observed to form a complete triangular ring. A specimen may have no branches, a branch on one foot and not on another, one on each foot, or two at different levels on the same foot. Some branches bifurcate; however, because of their fragmentary nature it is not certain if this is always the case.

Measurements (based on twenty specimens from Core 86-8). Length of cephalis and thorax together $95-120 \mu$ (majority $100-110 \mu$ ); width of thorax 110-125 $\mu$; length of feet $135-355 \mu$.

Remarks: This species differs from $B$. campechensis in the shorter length of the cephalis and thorax with the poreless portion of the thorax markedly shorter; and the more slender, widely divergent, smooth feet, which are not uniformly branched and generally curve outward distally.

\section{Genus BURYELLA Foreman, new genus}

Definition: Theoperids with a shell of four or more segments, without appendages, with at least one segment with pores arranged in transverse rows and the last segment not flared. Cephalis small with four collar pores and a vertical tube or pore at the collar stricture.

Remarks: This genus differs from Artostrobium by having a small cephalis with four collar pores.

Etymology: It is named for Mrs. P.S. Bury, the first woman to become interested in the study of Radiolaria, who published in 1862 "Figures of remarkable forms of Polycystins, or allied organisms, in the Barbados chalk deposit."

Type species: Buryella tetradica Foreman, new species.

\section{Buryella clinata Foreman, new species}

(Plate 8, Figures 1-3; Plate 9, Figure 19)

Lithocampe sp. Nigrini, in Cita, Nigrini, and Gartner, 1970, pl. 2, fig. M. Lithocampium sp. Riedel and Sanfilippo, 1970, p. 533, pl. 10, fig. 8.

Description: Shell of four segments, with none of the stricture expressed externally. Cephalis subspherical with a few very small circular pores, bearing a broad-based, sharp, bladed, apical horn, its length up to twice that of the cephalis. Ridges from the horn diverge and extend to the collar stricture except ventrally where two ridges rejoin to enclose a vertical pore and form an upwardly directed tube. Collar stricture internally with four collar pores. Thorax truncate-conical with circular pores randomly or quincuncially arranged. Third segment largest, inflated, its greatest dimension medianly or in the distal half, with circular to subcircular pores, quincuncially arranged in transverse and diagonal rows. Fourth segment inversely truncate-conical proximally, cylindrical distally with thinner wall, and pores subcircular to elliptical in transverse rows, termination ragged.
Measurements (based on fifteen specimens from 94-30, CC, 94-29, CC, and 94-28, CC). Length overall 140-195 $\mu$, length of cephalis and thorax $40-45 \mu$, of third segment $50-75 \mu$; greatest width $65-85 \mu$.

Remarks: The species described and illustrated here agrees well with the brief descriptions and illustrations of Nigrini and of Riedel and Sanfilippo. It differs only in its greater size. This species is related to and distinguished from $B$. tetradica as described under that species. It differs from Theocorys trisulca Kozlova (Kozlova and Gorbovetz, 1966, p. 111, pl. 17, fig. 9) in the nature of the third (second?) segment which is described as having a tuberculate surface and round, scalloped, doublecontoured pores, unequal in size and irregularly spaced.

The upward range of this form is not certain. It is present in almost all samples, common to rare, from Core 94-31 through Core 94-26. Above that level it occurs sporadically as a single, isolated specimen in rather widely separated samples, the latest in the Dorcadospyris ateuchus Zone of Hole 86.

\section{Buryella pentadica Foreman, new species (Plate 8, Figure 8; Plate 9, Figures 15, 16)}

Description: Shell of five segments, subovate, smooth, with none of the strictures expressed externally. Cephalis subspherical with a few circular pores, bearing a short, bladed or smooth conical horn. Collar stricture with four collar pores internally and a vertical pore expressed as a short, horizontally directed tube. Thorax and third segment conical, with circular pores in approximate transverse rows. Fourth segment largest, inflated, with greatest dimension medianly or in the distal half. Uniform circular pores are arranged in longitudinal and four to six, generally five, transverse rows. Area between longitudinal rows raised. Last segment truncate, inverted-conical, with a thinner wall and three to five transverse rows of circular to elliptical pores. Distal margin scalloped or even, without a differentiated rim.

Measurements (based on fifteen specimens from Core 86-8). Length overall, exclusive of horn, $130-150 \mu$, length of cephalis and thorax together $20-25 \mu$, of third segment $20-25 \mu$, of fourth segment $45-60 \mu$, of last segment $30-50 \mu$; greatest width $65-90 \mu$.

Remarks: This species is distinguished from its descendant $B$. tetradica as described under that species.

Buryella tetradica Foreman, new species (Plate 8, Figures 4, 5; Plate 9, Figures 13, 14)

Lithocampium sp. A Riedel and Sanfilippo, 1971, pl. 7, fig. 12.

Description: Shell of four segments subovate, smooth, with none of the strictures expressed externally. Cephalis subspherical, with a few circular pores, bearing a short, sharp horn or thorn. Collar stricture with four collar pores internally, and vertical pore expressed as a short horizontally directed tube. Thorax conical, with circular pores arranged in approximately three vague transverse rows or more irregular. Third segment largest, inflated, with greatest dimension medianly or in the distal half. Uniform circular pores are arranged in longitudinal and four to five transverse rows. Area between the longitudinal rows raised. Last segment inverted truncate-conical, with a smooth thinner wall and two to seven transverse rows of circular to elliptical pores. Distal margin scalloped or even, without a differentiated rim.

Measurements (based on twenty specimens from Cores 86-8, 96-3, 94-32, 94-31, and 94-30). Length overall, exclusive of horn, 120$185 \mu$, length of cephalis and thorax $35-45 \mu$, of third segment $40-$ $65 \mu$, of last segment $70-95 \mu$; greatest width $70-95 \mu$.

Remarks: The thorax of $B$. tetradica is considered homologous with the two postcephalic segments of $B$. pentadica. This difference in the number of segments between the cephalis and the large inflated segment serves to distinguish these two closely related species ( $B$. pentadica, ancestor and $B$. tetradica, descendant). $B$. tetradica differs from its descendant $B$. clinata by having pores of the third segment in transverse and longitudinal rows.

\section{Genus CALOCYCLAS Ehrenberg}

Calocyclas Ehrenberg, 1847b, table opposite p. 54. Type species (subsequent designation by Campbell, 1954, p. D132) Calocyclas turris Ehrenberg, 1873 , p. $218 ; 1875$, p. 66 , pl. 18 , fig. 7. 
Remarks: Campbell (1954, p. D132) designated Cycladophora stiligera Ehrenberg, 1873, p. 223; 1875, p. 68, pl. 18, fig. 3 as the type species of Cycladophora. However the legal type species (by subsequent monotypy) is Cycladophora tabulata Ehrenberg, 1872a, p. 306; 1872b, pl. 4, fig. 18. C. tabulata differs considerably from the type species of Calocyclas (Calocyclas turris) and therefore Cycladophora, indicated by Riedel and Sanfilippo, 1970, p. 529 (on the basis of types assigned by Campbell) as the senior subjective synonym of Calocyclas, is no longer so considered.

\section{Calocyclas hispida (Ehrenberg)}

(Plate 1, Figures 12-15; Plate 9, Figure 18)

Anthocyrtis hispida Ehrenberg, 1873, p. 216; 1875, pl. 8, fig. 2. Cycladophora hispida (Ehrenberg) Riedel and Sanfilippo, 1970, p. 529, pl. 10, fig. 9; 1971, pl. 3B, figs. 10, 11; Moore, 1971, pl. 4, figs. 6, 7. Remarks: Rare early forms appear to have narrower more widely spaced lamellar teeth at the apertural margin than do the more common younger forms. This species may have evolved from a form illustrated on Plate 1, Figure 16.

\section{Calocylas turris Ehrenberg}

Calocyclas turris Ehrenberg, 1873, p. 218 ; 1875, p. 66, pl. 18, fig. 7. Cycladophora turris (Ehrenberg) Riedel and Sanfilippo, 1970, p. 529, pl. 13, figs. 3, 4; Moore, 1971, pl. 4, fig. 8.

\section{Genus CALOCYCLOMA Haeckel}

Calocycloma Haeckel, 1887, p. 1384.

Calocycloma ampulla (Ehrenberg)

(Plate 1, Figures 1-5; Plate 9, Figure 20)

Eucyrtidium ampulla Ehrenberg, 1854, pl. 36, figs. 15a-c; 1873, p. 225; 1875 , p. 70 , pl. 10 , figs. $11,12 \mathrm{a}-\mathrm{b}$.

Dictyocephalus ampulla (Ehrenberg) Haeckel, 1862, p. 297.

Sethamphora ampulla (Ehrenberg) Haeckel, 1887, p. 1251.

Calocycloma (?) ampulla (Ehrenberg) Riedel and Sanfilippo, 1970, p. 524 , pl. 6, fig. 1 .

Remarks: specimens observed here agree well with those described and illustrated by Riedel and Sanfilippo. The earliest forms as noted by them have small pores and a somewhat less elongated proximal thorax. In addition, the collar stricture has four collar pores internally. This species differs from Calocycloma castum (Haeckel) as described under that species. Not included are forms (Plate 1, Figure 6) with large irregular pores and a much less constricted aperture.

\section{Calocycloma castum (Haeckel)}

Calocyclas casta Haeckel, 1887, p. 1384 , pl. 73, fig. 10. Calocyclas casta Haeckel, in Cita, Nigrini, and Gartner, 1970, p. 404 , pl. 2, fig. H.

Description: Shell generally of two segments, subpyriform. Cephalis subspherical, poreless, or with a very few small pores; occasionally spiny; bearing a cylindro-conical horn. Collar stricture well defined externally and with four collar pores internally. Thorax proximally conical with small circular pores sometimes arranged in vague longitudinal rows, remainder inflated with very large circular to subangular pores, surface generally with large, slender, conical spines at the junctions of the intervening pore bars. Aperture surrounded by a rounded rim which may be smooth or bear irregularly developed, small, downwardly directed spines or thorns. Some similar early forms (plate 1, Figure 8) with a wider aperture, sometimes with attached fragments of lattice rather than thorns, are not included.

Measurements (based on twenty specimens from 94-31, CC, Core 94-30, 94-29, CC, and Core 94-28). Length overall, exclusive of horn, $15-220 \mu$ (majority $150-185 \mu$; greatest width $100-185 \mu$; greatest diameter of pores $20-37 \mu$, of aperture $35-75 \mu$.

Remarks: Although this species has in the past been reported as consisting of three segments, there is no internal segmental division at the point where the size of the pores and the external contour of the thorax changes. The species described here agrees well with the species illustrated by Nigrini.

It differs from the form described and illustrated by Haeckel only in having no or only a very few pores on the cephalis, and long downwardly directed spines which originate on the distal thorax, near but not on the rounded rim. $C$. castum differs from the forms of $C$. ampulla with which it cooccurs in having larger pores and a less globose, more pyriform thorax. It probably arose from a form, very rare in this material, such as is illustrated in Plate 1, Figure 11.

\section{Genus CLATHROCYCLOMA Haeckel}

Clathrocycloma Haeckel, 1887, p. 1388.

Remarks: The internal cephalic structure of Clathrocyclas alcmenae Haeckel, 1887, the type species (designated by Campbell, 1954, p. D132) of Clathrocycloma, is not known, but it very likely has four collar pores. Externally it differs from the species here assigned to that genus only by having a vertical spine rather than a vertical tube. Foreman (1968) described three similar species with tubes and collar pores as for $C$. capitaneum, from the upper Maestrichtian, and assigned them questionably to the genus Clathrocyclas. Pessagno (1969) described a single species with structures as for those of the species described by Foreman (1968) and assigned it to a new genus Coniforma Pessagno. In the material studied the two similar species differ in having six (Clathrocycloma capitaneum) and four (C. parcum) collar pores respectively. Because the significance of the difference ( $C$. parcum and possible Clathrocyclas alcmenae) in the collar pores is not understood, it does not seem appropriate to assign these otherwise externally similar species to different genera, and we continue to use Haeckel's nomenclature.

In the material examined no specimens assignable to Clathrocycloma with prominent long vertical tubes as for $C$. capitaneum and $C$. parcum were present above the level of Core 86-7, though forms with vertical horns or less prominent tubes are common in Core 96-3 (Plate 2, Figures 11 and 12) and less common in younger assemblages.

\section{Clathrocycloma capitaneum Foreman, new species}

(Plate 2, Figure 15; Plate 11, Figure 11)

Description: Cephalis subspherical, poreless, smooth, or slightly nodose, bearing a smooth conical horn which leaves the cephalis obliquely directed away from a long, slender vertical tube which varies in the angle at which it leaves the cephalis. It may be almost vertical or almost horizontal, but generally is in between at about 45 degrees from the vertical. Internally collar stricture with six collar pores, jugular pores very small. Externally collar stricture not expressed. Thorax long, campanulate, somewhat variable in shape, generally increasing gradually in width to approximately the fourth to sixth transverse row of pores and then flaring more sharply, sometimes sides almost vertical medianly before flare. Margin ragged, never observed complete. The proximal thorax is poreless, sometimes with pore-shaped depressions, and bears tiny lateral and dorsal wings. Proximal pores are small, circular, generally with prongs on their margin. Distally they increase rapidly in size and generally become angular, polygonal to rectangular in shape. Sometimes the development of one or two internal ledges between the median rows of pores gives the impression of a segmental division, but this very variable feature is not considered significant and all of the post-cephalic shell is here treated as the thorax.

Measurements (based on ten specimens from Core 86-8). Length of cephalis and thorax to fourth row of thoracic pores $125-170 \mu$; width of thorax at fourth row of thoracic pores $115-140 \mu$.

Remarks: Not included in this species is a similar rare form (Plate 2, Figure 15) which has a cephalis with short spines apically, generally diagonal ridges between the distal thoracic pores, and generally a distinct constriction with some segmental division before flaring sharply. The first or second row of post-constriction pores smaller than or rarely equal in size to those immediately above. $C$. capitaneum differs from $C$. parcum as described under that species.

\section{Clathrocycloma parcum Foreman, new species (Plate 2, Figure 13; Plate 11, Figure 12)}

Description: Cephalis subspherical, with many or few circular pores bearing a long, slender, generally upright conical horn and a long, horizontal to slightly upwardly directed cephalic tube. Collar stricture internally with four collar pores, externally well defined. Thorax long, campanulate, with sides almost vertical medianly and constricting slightly before flaring distally at about the sixth or seventh transverse row of pores; proximally with tiny dorsal and lateral wings; margin ragged, never observed complete. Thorax with pores overall, small, circular proximally; larger, circular to subangular distally. Sometimes the 
development of a slight ledge at the point where the pore size changes, and more sturdy ledges between the distal pore rows, gives the impression of segmental divisions, but this very variable feature is not considered significant and all of the post-cephalic shell is here treated as the thorax.

Measurements (based on ten specimens from Core 86-8). Length of cephalis and thorax to fifth row of thoracic pores 70-95 $\mu$; width of thorax at fifth row of thoracic pores $65-80 \mu$.

Remarks: This species differs from $C$. capitaneum in its smaller size, presence of pores on the proximal thorax, and collar stricture with four collar pores.

\section{Genus CYCLAMPTERIUM (?) Haeckel}

Cyclampterium? Haeckel, 1887, Sanfilippo and Riedel, 1970, p. 456.

\section{Cyclampterium (?) leptetrum}

Cyclampterium? leptetrum Sanfilippo and Riedel, 1970, p. 456, pl. 2, figs. 11, 12; Riedel and Sanfilippo, 1971, pl. 2D, figs. 9-12; Kling, 1971, pl. 5 , figs. J, K.

\section{Cyclampterium (?) milowi Riedel and Sanfilippo}

Cyclampterium? milowi Riedel and Sanfilippo, 1971, pl. 3B, fig. 3; pl. 7 , figs. 8,9 .

\section{Cyclampterium (?) pegetrum Sanfilippo and Riedel}

Cyclampterium? pegetrum Sanfilippo and Riedel, 1970, p. 456, pl. 2, figs. 8-10; Riedel and Sanfilippo, 1971, pl. 2D, figs. 13, 14; Kling, 1971, pl. 5, fig. I.

Remarks: In the material studied, Cyclampterium (?) milowi Riedel and Sanfilippo, 1971, could not always be distinguished from its immediate descendant $C$. (?) pegetrum because the distinguishing feet were frequently broken off.

\section{Genus CYRTOCAPSELLA Haeckel}

Cyrtocapsella Haeckel, 1887, Sanfilippo and Riedel, 1970, p. 451; Riedel and Sanfilippo, 1970, p. 530.

\section{Crytocapsella cornuta (Haeckel)}

Cyrtocapsa cornuta Haeckel, 1887, p. 1513, pl. 78, fig. 9.

Cyrtocapsella cornuta Haeckel, in Sanfilippo and Riedel, 1970, p. 453 , pl. 1, figs. 19, 20; Riedel and Sanfilippo, 1970, p. 531, pl. 4 , fig. 8 ; 1971 , pl. $2 \mathrm{E}$, figs. $1-4$; Kling, 1971 , pl. 2 , fig. G.

\section{Cyrtocapsella tetrapera (Haeckel)}

Cyrtocapsa tetrapera Haeckel, 1887, p. 1512, pl. 78, fig. 5.

Cyrtocapsella tetrapera Haeckel, in Sanfilippo and Riedel, 1970, p. 453, pl. 1, figs. 16-18; Riedel and Sanfilippo, 1970, p. 530, pl. 14 , fig. $7 ; 1971$, pl. 2 E, figs. $5-7$; Kling, 1971, pl. 2, fig. C; Moore, 1971, pl. 11, figs. 6, 7 .

\section{Cry tocapsella elongata (Nakaseko)}

Theocapsa elongata Nakaseko, p. 185, pl. 3, figs. 4, 5 .

Cyrtocapsella elongata (Nakaseko) Sanfilippo and Riedel, 1970, p. 452, pl. 1, figs. 11, 12 .

\section{Genus DICTYOCERAS Haeckel}

\section{Dictyoceras Haeckel, 1862, p. 333.}

Remarks: The species described below and the type species of Dictyoceras (probably by absolute tautonymy) Lithornithium dictyoceras Haeckel, 1860 , p. 840 , a Recent form, are certainly not closely related. Its assignment here to Dictyoceras is therefore made only as a matter of convenience until the relationship of this species to other forms is clearer.

\section{Dictyoceras caia Foreman, new species}

(Plate 2, Figure 7; Plate 9, Figure 21)

Description: Cephalis subspherical with numerous, small, circular pores bearing a large, sturdy, club-shaped horn, which has a surface roughened by irregular striae and distally irregular pits. Collar stricture with four collar pores internally is not well defined externally. A vertical pore is expressed as a short tube at the collar stricture. Thorax triangular in transverse section, with circular to subcircular pores irregular in size, shape, and arrangement. Hollow porous wings pinch off from the distal thorax and terminate in a solid, lightly striated tip at the level of the abdomen. Abdomen triangular in transverse section, frequently connected to the proximal wings by porous shell material, rarely with a stricture delineating a fourth segment; pores as for thorax and distal margin ragged.

Measurements (based on fifteen specimens from Core 86-8 and $86-7$, CC). Length of cephalis and thorax $70-80 \mu$, of horn $65-90 \mu$; diameter of lumbar stricture $55-65 \mu$.

Remarks: The large club-shaped horn, proximally pinched-off hollow wings, and triangular transverse section distinguish this form from all others.

\section{Genus EUSYRINGIUM Haeckel}

Eusyringium Haeckel, 1881, p. 437.

\section{Eusyringium fistuligerum (Ehrenberg)}

(Plate 11, Figure 6)

Eucyrtidium fistuligerum Ehrenberg, 1873, p. 229; 1875, p. 70, pl. 9, fig. 3.

Eusyringium fistuligerum (Ehrenberg) Riedel, 1957a, p. 94, pl. 4, fig. 8; Riedel and Sanfilippo, 1970, p. 527, pl. 8, figs. 8, 9; Moore, 1971, pl. 4, figs. 10, 11.

Remarks: Specimens observed here agree well with the description of Riedel and of Riedel and Sanfilippo. The collar stricture has four collar pores and an upwardly directed vertical pore emerging from the thick thoracic wall which envelopes the basal cephalis.

\section{Eusyringium lagena (Ehrenberg) (?)}

(Plate 11, Figures 4, 5)

[?] Lithopera lagena Ehrenberg, 1873, p. 241; 1875, p. 78, pl. 3, fig. 4.

[?] Sethopera lagena (Ehrenberg) Haeckel, 1887, p. 1233.

[?] Sethocapsa lagena Haeckel, 1887, p. 1310.

[?] Sethocapsa pyriformis Haeckel, 1887, p. 1310, pl. 57, fig. 2. Eusyringium lagena (Ehrenberg) (?) Riedel and Sanfilippo, 1970, p. 527, pl. 8, figs. 5-7.

Remarks: Specimens observed here agree well with those described by Riedel and Sanfilippo except that rare forms have ribs which protrude as short wings on the median thorax. In addition the collar stricture has four collar pores internally, with an upwardly directed vertical pore emerging from the thoracic wall, which encloses the basal cephalis. The species illustrated here is only doubtfully referred to the three species described by Ehrenberg and Haeckel because the illustration of Ehrenberg and the generic assignments of Haeckel all indicate forms without aperture.

\section{Genus LAMPTONIUM Haeckel}

Lamptonium Haeckel, 1887, p. 1378.

Remarks: The relationship of all of the species, here assigned to Lamptonium, to the type species of that genus (designated by Campbell, 1954, p. D132), Cycladophora enneapleura Haeckel, 1887, p. 1378, is not certain.

Of these L. sanfilippoae, L. fabaeforme (?) chaunothorax, L. fabaeforme (?) constrictum, L. fabaeforme fabaeforme (?), and $L$. pennatum are clearly related. However, the relationships, if any, of $L$. (?) colymbus and $L$. (?) incohatum to each other or to the five species listed above is not understood and they are thus tentatively assigned.

\section{Lamptonium (?) colymbus Foreman, new species}

(Plate 6, Figure 2; Plate 11, Figures 15, 19)

Description: Shell large, of two segments, with inflated thorax bearing wings. Cephalis subspherical, with a few circular pores, and bearing a bladed horn never observed complete. Collar stricture with six collar pores internally, externally indistinct, contour of cephalis merges with that of thorax. Thorax proximally truncate-conical, distal three-quarters inflated or expanded, with approximately straight sides, bearing three three-bladed wings extending from upper part of inflated thorax. Distally thorax constricted, aperture surrounded by a smooth, rarely roughened rim. Pores generally circular to subcircular, regularly quincuncially arranged in longitudinal rows, rarely more irregular in shape and arrangement. Surface roughened with tiny nodes.

Measurements (based on twenty specimens from Core 86-8 and 86-7, CC). Length of cephalis and thorax, exclusive of horn, 160-210 ; greatest width of thorax $145-180 \mu$.

Remarks: This species is distinguished from $L$. pennatum by its lack of a third segment and larger size from $L$. (?) incohatum as described under that species. 
Lamptonium fabaeforme (?) chaunothorax Riedel and Sanfilippo (Plate 6, Figures 10-12)

Lamptonium (?) fabaeforme (?) chaunothorax Riedel and Sanfilippo, 1970, p. 524, pl. 5, figs. 8, 9.

Lamptonium fabaeforme (?) constrictum Riedel and Sanfilippo (Plate 6, Figures 13, 14)

Lamptonium (?) fabaeforme (?) constrictum Riedel and Sanfilippo, 1970, p. 523, pl. 5, fig. 7; Moore, 1971, pl. 1, fig. 7.

Remarks: Specimens agree well with the description and illustrations of Riedel and Sanfilippo. There are six collar pores at the collar stricture.

Lamptonium fabaeforme fabaeforme (Krasheninnikov) (?) (Plate 6, Figures 6-9)

[?] Cyrtocalpis fabaeformis Krasheninnikov, 1960, p. 296, pl. 3, fig. 11. Lamptonium (?) fabaeforme fabaeforme (Krasheninnikov) (?) Riedel and Sanfilippo, 1970, p. 523, pl. 5, fig. 6.

Remarks: The species illustrated here agrees well with that described and illustrated by Riedel and Sanfilippo. It differs only in that the older forms are smaller and have more nodose, less spiny surface. In addition the pores may have uneven margins or prongs and internally the collar stricture has six collar pores.

\section{Lamptonium (?) incohatum Foreman, new species}

(Plate 6, Figure 1; Plate 11, Figure 18)

Description: Shell large, of two segments with thorax very inflated. Cephalis subspherical, with a few circular pores, surface nodose to spiny, bearing a short, cylindro-conical, apical horn. Collar stricture with six collar pores internally, externally indistinct, contour of cephalis merges with that of thorax. Thorax proximally truncate-conical, distal threequarters expanded with generally approximately straight sides. Aperture constricted, with a smooth, not prominent rim. Three feet (never observed complete), generally slender, smooth, occasionally heavier, thorny, depend vertically from the distal thoracic wall. Specimens with heavier feet generally also have fragments of lattice extending from the lower margin of the thorax. Pores circular to subcircular, frequently with uneven margins, quincuncially arranged in distinct longitudinal rows which are sometimes emphasized by weak angular pore frames appearing more distinct longitudinally and thus giving the impression of undulating longitudinal ridges between the pores. Surface smooth or slightly roughened by tiny nodes or thorns.

Measurements (based on twenty specimens from Core 86-8). Length of cephalis and thorax, exclusive of horn and feet, 190-220 $\mu$; greatest width of thorax $190-215 \mu$.

Remarks: Rare specimens with a longer, more developed branched foot and rare specimens with fragments of lattice below the second segment suggest the possible presence of a third segment with pores very variable in size. This species is distinguished from $L$. (?) colymbus by the presence of feet, absence of wings, and its larger size.

Lamptonium pennatum Foreman, new species

(Plate 6, Figures 3-5; Plate 11, Figure 13)

Description: Cephalis subhemispherical, with a few circular pores and pore-shaped depressions, and bearing a sturdy bladed horn. Collar stricture with six collar pores internally, not expressed externally, contour of cephalis merging with that of inflated thorax. Thoracic pores circular to subcircular, occasionally uneven or with prongs on their margin, generally regularly quincunically arranged in longitudinal rows; surface roughened with pointed nodes. Three three-bladed wings extend outward from the median thorax. Abdomen subcylindrical, fragile, lamellar, with circular to elliptical pores; termination ragged.

Measurements (based on twenty specimens from Core 86-8 and 86-7, CC). Length of cephalis and thorax, exclusive of horn, $125-150 \mu$; greatest width of thorax $100-140 \mu$, width of proximal abdomen $60-80 \mu$.

Remarks: This species is apparently a precursor of Lamptonium fabaeforme fabaeforme (?) from which it differs by the presence of wings and less elongated proximal thorax.

Lamptonium sanfilippoae Foreman, new species

(Plate 6, Figures 15, 16; Plate 11, Figures 16, 17)

Description: Shell of two segments, pyriform, with collar stricture not expressed externally. Cephalis subhemispherical, with a massive layer of rough shell material apically from which extends a bladed horn frequently broken. Internally the collar stricture has five collar pores, the vertical spine rising so sharply that it does not divide the cervical pore. Thorax proximally with or without one or two slight constrictions, basally closed, and tending to be flattened. Circular to subcircular pores with or without prongs on their margin may be largest medianly at point of greatest expansion and distinctly smaller, less regularly arranged basally, or more regular in size, tending to longitudinal alignment; surface spiny.

Measurements (based on fifteen specimens from Core 94-30, 94$29, \mathrm{CC}, 94-28, \mathrm{CC}$, and $95-9, \mathrm{CC})$. Length overall, exclusive of horn, $210-325 \mu$; greatest width $130-205 \mu$.

Remarks: Specimens with a slight constriction on the proximal thorax, smaller more regular pores, and a less spiny surface are present in the younger samples. However, the number of specimens observed is too few to divide the species on the basis of these features.

These forms are apparently related to species of Lamptonium (?) described by Riedel and Sanfilippo (1970). Similarities include the shape of the thorax, the distinctive pores and surface spines, and the development of massive structure (large horn or massive layer of shell material) apically. They differ primarily in the absence of a subcylindrical, distally open third segment. A vague circular line basally, together with the less regular basal pores, suggest an earlier aperture.

This form, rare here is common in DSDP Leg 2, sample 10-9$3(125-127 \mathrm{~cm})$ from the mid-Atlantic, $32^{\circ} 37^{\prime} \mathrm{N}, 52^{\circ} 20^{\prime} \mathrm{W}$. The Leg 2 forms resemble the younger forms described here.

This Early Eocene closed theoperid is named for Annika Sanfilippo in recognition for her work, together with William R. Riedel, on post-Eocene closed theoperids.

\section{Genus LITHOCHYTRIS Ehrenberg}

Lithochytris Ehrenberg 1847a, chart to p. 385.

\section{Lithochytris archaea Riedel and Sanfilippo}

(Plate 2, Figures 4, 5)

Lithochytris archaea Riedel and Sanfilippo, 1970, p. 528, pl. 9, fig.7; 1971, pl. 7 , fig. 13.

Remarks: Early forms (Plate 2, Figure 5) and late forms (Plate 2, Figure 4) agree well with the illustrations of Riedel and Sanfilippo. The early forms are distinguished by relatively longer thoracic and shorter abdominal segments, and feet more prominent, less integrated in the shell wall.

In the material here available it seems clear that $L$. archaea evolved from Lychnocanoma auxilla, by the more complete development of the third segment. The relationship of cephalis to thorax remains the same, differing only in that the asymmetry associated with the large vertical pore of $L$. auxilla is less evident in the younger Lithochytris archaea with its smaller thorax and thicker shell wall.

L. archaea differs from Stichopera ponderosa Kozlova, in Kozlova and Gorbovetz, 1966, p. 114, pl. 17, fig. 10, in having only three segments.

Lithochytris vespertilio Ehrenberg

(Plate 2, Figures 2, 3; Plate 11, Figure 3)

Lithochytris vespertilio Ehrenberg, 1873, p. 239; 1875, pl. 4, fig. 10; Riedel and Sanfilippo, 1970, p. 528, pl. 9, figs. 5, 6; Moore, 1971, pl. 4, fig. 4.

\section{Genus LITHOPERA Ehrenberg}

Lithopera Ehrenberg, 1847a, chart to p. 385; Sanfilippo and Riedel, 1970, p. 454.

Lithopera (Lithopera) renzae Sanfilippo and Riedel

Lithopera (Lithopera) renzae Sanfilippo and Riedel, 1970, p. 454, pl. 1, figs. 21-23; 1971, pl. 2E, figs. 17, 18; pl. 7, fig. 14.

\section{Genus LOPHOCYRTIS Haeckel}

Lophocyrtis Haeckel, 1887, p. 1410; Riedel and Sanfilippo, 1970, p. 529.

\section{Lophocyrtis (?) jacchia (Ehrenberg)}

Thyrsocyrtis jacchia Ehrenberg, 1873 , p. $261 ; 1875$, p. 84, pl. 12, fig. 7. Lophocyrtis (?) jacchia (Ehrenberg) Riedel and Sanfilippo, 1970, p. 530; 1971, pl. 3C, figs. 4, 5; pl. 7, fig. 16; Moore, 1971, pl. 5, figs. 4, 7. 


\section{Genus LYCHNOCANOMA Haeckel}

Lychnocanoma Haeckel, 1887, p. 1229.

Remarks: Lychnocanoma, type species (designated by Campbell, 1954, p. D124) Lychnocanoma clavigerum Haeckel, 1887, p. 1230, pl. 61, fig. 4 , is here used as the generic name for two-segmented theoperids with three feet, without accompanying ribs in the thorax, and without a large cephalis as in Bekoma Riedel and Sanfilippo (1971).

The seven species assigned here include two distinct lineages which are not closely related to each other: the Lychnocanoma sp. aff. $L$. bellum $-L$. amphitrite lineage and the Lychnocanoma auxilla- $L i$ thochytris vespertilio lineage which may have originated from a species in the Lychnocanoma babylonis group. The species $L$. anacolum and $L$. bipes are not related to either lineage or to each other.

\section{Lychnocanoma amphitrite Foreman, new species} (Plate 11, Figure 10)

[?] Lychnocanium sp. aff. L. bellum Campbell and Clark, in Riedel and Sanfilippo, 1971, pl. 3C, figs. 1, 2.

Description: Cephalis and thorax similar to L. bellum. Differs in larger size and more massive wall of thorax and relatively shorter feet. Third segment triangular in cross-section, inverted subhemispherical to subpyramidal, with very irregular pores. Hollow feet incorporated in shell wall except distally where they protrude outwardly, solid, short, stubby, and bladed.

Measurements (based on twenty specimens from 86-6, CC, Cores 95-6 and 94-14). Length overall, exclusive of horn, 190-280 $\mu$, length of cephalis and thorax $140-175 \mu$, of abdomen $40-110 \mu$; greatest width of thorax $150-190 \mu$.

Remarks: Later specimens tend to have the horn become slightly bladed, and very late specimens, at least in the samples studied here, have a less robust abdomen with the feet less integrated in the shell wall. Sometimes only a fragment of this third segment is present at the base of the feet. This species is distinguished from its ancestor $L$. bellum by the larger size of the thorax, and relatively shorter feet with outwardly directed, stubby, bladed termination. It may be conspecific with Lychnocanium sp. aff. L. bellum Riedel and Sanfilippo, from which it differs primarily in that the abdomen is latticed rather than spongy.

\section{Lychnocanoma anacolum Foreman, new species}

(Plate 1, Figure 19; Plate 11, Figure 7)

Description: Cephalis subhemispherical with numerous small pores, bearing a stout conical horn which may be smooth or ridged, sometimes with a slightly roughened tip. The collar stricture, with six collar pores, is well defined externally. Thorax short, campanulate, with relatively large circular to subcircular pores, irregular in size and distribution, and smooth surface. Three sturdy, curved, three-bladed feet with marked convexity outward, depend from the distal thorax. Generally an irregularly porous, lamellar lattice extends from the distal thorax and joins the feet proximally.

Measurements (based on twenty specimens from Core 86-8 and 86-7, CC). Length of cephalis and thorax $60-70 \mu$, of horn $30-65 \mu$, of feet $55-155 \mu$; greatest width of thorax $70-75 \mu$.

Remarks: This species may be distinguished from other two-segmented forms with curved bladed feet by the combination of a stout, relatively long horn, short thorax with large irregular pores, and sturdy, curved, three-bladed feet with convexity outward.

\section{Lychnocanoma auxilla Foreman, new species} (Plate 2, Figure 6; Plate 11, Figures 1,2)

Description: Shell of two complete segments, a fragile, generally incomplete, third segment, and three feet; first two segments pyriform with contour of cephalis and thorax merging. Cephalis subspherical with a few, small, circular pores bearing a stout, finely striated, conical horn; internally collar stricture with four collar pores; externally an upwardly directed vertical pore opens from the thick thoracic wall which envelopes the basal cephalis. Thorax subcampanulate, asymmetric proximally where the vertical pore expands the shell wall; surface smooth or finely papillate; pores subcircular, frequently with uneven margins, irregular in size, shape, and distribution. Three stout, finely striated feet depend from the distal thorax. A third segment with a thin, fragile, irregularly porous wall joins the three feet proximally. When broken away or not well developed, tiny thorns on the inner margin of the proximal feet and fragments attached to the thorax indicate its probable presence.

Measurements (based on twenty specimens from Core 96-3, 94-

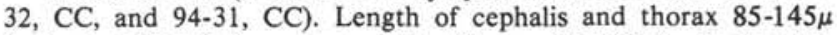
(majority 100-120 $\mu$ ); greatest width of thorax $85-133 \mu$ (majority 100 $115 \mu)$.

Remarks: This species is distinguished from a probable ancestor in the Lychnocanoma babylonis group by the presence of partially developed fragile third segment and from its descendant Lithochytris archaea by the lack of a completely developed third segment.

\section{Lychnocanoma babylonis (Clark and Campbell) group} (Plate 2, Figure 1)

Dictyophimus babylonis Clark and Campbell, 1942, p. 67, pl. 9, figs. 32, 36.

Sethochytris babylonis (Clark and Campbell) group, Riedel and Sanfilippo, 1970, p. 528, pl. 9, figs. 1-3; Moore, 1971, pl. 3, figs. 9, 10.

Remarks: It seems likely that Lychnocanoma auxilla arose from species in this group through the addition of its partially developed third segment.

\section{Lychnocanoma bellum (Clark and Campbell)}

(Plate 1, Figure 17; Plate 11, Figure 9)

Lychnocanium bellum Clark and Campbell, 1942, p. 72, pl. 9, figs. 35, 39; Riedel and Sanfilippo, 1970, p. 529, pl. 10, fig. 5.

Lychnocanium sp. Riedel, 1957 b, p. 259 , pl. 63 , fig. 5 .

Remarks: The species illustrated here agrees well with the illustrations and descriptions of Clark and Campbell, Riedel, and Riedel and Sanfilippo. In addition the collar stricture has four collar pores internally, and occasional specimens possess fragments of a partially developed third segment between the feet. Always rare or present only as an isolated specimen, it is found in some samples from $94-30(\mathrm{CC})$ through sample $94-15(C C)$.

\section{Lychnocanoma bipes (Riedel)}

Lychnocanium bipes Riedel, 1959, p. 294, pl. 2, figs. 5, 6; Riedel and Sanfilippo, 1970, p. 529, pl. 15, fig. 8; 1971, pl. 2F, figs. 1, 2; Kling, 1971, pl. 5, fig. E.

\section{Lychnocanoma sp. aff. L. bellum (Campbell and Clark)} (Plate 1, Figure 18; Plate 11, Figure 8)

Description: Cephalis and thorax as for Lychnocanoma bellum. Differs only in that the feet, instead of being uniformly hollow as in L. bellum, are irregularly porous.

Remarks: This species is apparently the precursor of $L$. bellum. It is extremely rare in the material studied.

Genus ORBULA Foreman, new genus

Definition: Shell of two segments with cephalis similar to Bekoma, thorax constricted distally, with three ribs terminating in three solid, short feet.

Remarks: This genus differs from Lamprodiscus Ehrenberg, 1860, type species (designated by Campbell, 1954, p. D122) Lamprodiscus monoceros Ehrenberg $1872 \mathrm{a}$, p. $314 ; 1872 \mathrm{~b}$, pl. 7, fig. 2, and from Bekoma Riedel and Sanfilippo (1971), type species (by monotypy) Bekoma bidarfensis in having a basally constricted thorax and thoracic ribs emerging as unbranched feet above the aperture. It differs from Lychnocanium Ehrenberg 1847a, type species (by subsequent monotypy) Lychnocanium lucerna Ehrenberg $1847 \mathrm{~b}$, fig. 5, by its large cephalis.

The large thick-walled, poreless, distinctive cephalis with six collar pores of both Bekoma and Orbula are very similar (Figures 4 and 5). This similarity may, as a result of further study, provide the basis for removing these two genera from the large polyphyletic Theoperidae.

Etymology: The name is a diminutive form of the Latin Orba, orphan (feminine).

Type species: Orbula ducalis Foreman, new species.

Orbula comitata Foreman, new species

(Plate 3, Figure 11; Plate 10, Figures 7, 8; Figure 5)

Description: Cephalis subspherical, circular to subtriangular in transverse section, with thick wall, bearing a conical or rodlike apical horn and frequently tiny vertical and secondary lateral spines. Cephalis and proximal thorax poreless, surface minutely papillate, often with circular pore-shaped depressions. Collar stricture internally with six 
collar pores, the collar structures very weak, and rarely preserved whole (Figure 5). Externally contour of cephalis merges with thorax. Thorax with circular to subcircular pores very variable in size, quincuncially arranged in approximate longitudinal rows; surface tuberculate. Thorax subspherical when viewed laterally, circular to subtriangular in transverse section. Three short, basally ridged feet extend from the thorax at the point where it begins to constrict. Aperture circular to subtriangular, surrounded by a rounded rim with surface ridged or minutely papillate.

Measurements (based on fifteen specimens from Core 86-8-4 and $86-7, \mathrm{CC})$. Length of cephalis and thorax $160-185 \mu$; greatest width of thorax $150-200 \mu$.

Remarks: This species differs from $O$. ducalis in its smaller size and the shape of the cephalis and thorax, and from $O$. discipulus as described under that species.

Orbula discipulus Foreman, new species

(Plate 3, Figure 10; Plate 10, Figures 9, 10)

Description: Cephalis subspherical, poreless, but with numerous circular, pore-shaped depressions, bearing a slender cylindrical horn never observed complete, and sometimes tiny vertical and secondary lateral spines. Surface of cephalis and proximal thorax roughened with minute papillae. Collar stricture well defined externally, internally with six collar pores, as for $O$. comitata but with collar structures not so weak. Thorax unevenly campanulate, except distally where it constricts to terminate in an apertural rim with surface minutely papillate. Three ribs extend approximately two-thirds down the length of the thorax, terminating as three short, rodlike feet at the point where the thorax begins to constrict. Thoracic pores angular to subcircular, irregular in size and arrangement; surface tuberculate.

Measurements (based on twenty specimens from Core 86-8 and 86-7. CC). Length overall, exclusive of horn, 180-230 $\mu$; greatest width of thorax $190-255 \mu$, diameter of aperture $105-140 \mu$.

Remarks: This species is distinguished from $O$. ducalis by its shape and irregularly arranged pores, and from $O$. comitata by its greater size and irregularly arranged and relatively smaller pores.

\section{Orbula ducalis Foreman, new species}

(Plate 3, Figure 12, Plate 10, Figures 11, 12)

Description: Cephalis subspherical in lateral view, subtriangular in transverse section, with corners of triangle truncate coinciding with position of vertical and secondary lateral bars which protrude as tiny thorns. Apical horn may be small, thorn-like, or larger and cylindrical. Cephalis and proximal thorax poreless, minutely papillate. Cephalis pitted apically, distally frequently nodose. Internally the collar stricture has six collar pores as in $O$. comitata. Externally the collar stricture not distinct as the contour of the cephalis merges with that of the thorax. Thorax with two distinct flaring expansions, the distalmost much broader than the first; subtriangular in transverse section. Aperture constricted, subtriangular, surrounded by a rounded rim with surface minutely papillate. Three ribs extend from the collar stricture and terminate in three short feet at the point where the thorax constricts. Thoracic pores subcircular, arranged quincuncially in vertical rows, gradually increasing in size to the point of greatest expansion; surface tuberculate.

Measurements (based on twenty specimens from Core 86-8-4 and $86-7, \mathrm{CC})$. Length of cephalis and thorax $100-150 \mu$; greatest width of thorax $190-245 \mu$, of aperture $120-160 \mu$.

Remarks: This species is distinguished from $O$. comitata and $O$. discipulus as described under those species.

\section{Genus PHORMOCYRTIS Haeckel}

Phormocyrtis Haeckel, 1887, p. 1368.

Remarks: Phormocyrtis striata striata and the other species assigned here to Phormocyrtis, type species (designated by Campbell, 1954, p. 134D), Phormocyrtis longicornis Haeckel, 1887, p. 1370, pl. 69, fig. 15, are probably not closely related to that species. They do appear, however, to have some relationship to each other (cephalic structure and the relation of the cephalis to the thorax, longitudinal pores, and shape), and on that basis they are all assigned to this same genus.

\section{Phormocyrtis cubensis (Riedel and Sanfilippo)}

(Plate 7, Figures 11, 12, 14)

Eucyrtidium cubense Riedel and Sanfilippo, 1971, pl. 7, figs. 10, 11.

Remarks: Specimens observed here agree well with the species described and illustrated by Riedel and Sanfilippo. There are six collar pores, the two jugular pores very small, and an upwardly directed vertical pore emerging from the thoracic wall which envelopes the basal cephalis.

A similar rare form with large expanded abdomen, and no spongy structure in the distalmost cylindrical segment (Plate 7, Figure 13), first present in Sample 94-31(CC), may be a descendant and possibly referable to Tricolocampe vitrea Krasheninnikov, 1960, pl. 299, pl. 3, fig. 14 .

A distinctive form (Plate 7, Figure 15), possibly related to $P$. cubensis, cooccurs in part of the range of the latter.

\section{Phormocyrtis striata striata Brandt}

(Plate 7, Figures 5, 6, 9)

Phormocyrtis striata Brandt, in Wetzel, 1935, p. 55, pl. 9, fig. 12; Riedel and Sanfilippo, 1970, p. 532, pl. 10, fig. 7.

Description: $P$. striata striata is here limited to those forms having the abdomen circular in transverse section. Specimens observed agree well with those described by Riedel and Sanfilippo. The collar stricture has four collar pores with a vertical pore emerging from the thoracic wall which envelopes the basal cephalis.

Phormocyrtis striata exquisita (Kozlova)

(Plate 7, Figures 1-4, 7, 8; Plate 12, Figure 5)

Podocyrtis exquisita Kozlova, in Kozlova and Gorbovetz, 1966, p. 106 , pl. 17, fig. 2 .

Phormocyrtis striata Brandt, Riedel and Sanfilippo, 1971, pl. 8, fig. 4.

Description: Shell as for Phormocyrtis striata striata, with the exception that the abdomen is triangular in transverse section with early forms frequently having keels at the angles of the triangle, and pores less regular in shape and arrangement.

Measurements (based on twenty specimens from 86-8, CC, 96-3-6, 94-32, CC, and 94-31, CC). Length overall, exclusive of horn, 150$220 \mu$; greatest width of abdomen $70-130 \mu$.

\section{Phormocyrtis turgida (Krasheninnikov)}

(Plate 7, Figure 10; Plate 12, Figure 6)

Lithocampe turgida Krasheninnikov, 1960, p. 301, pl. 3, fig. 17.

Description: Shell of four segments, spindle-shaped, thick, smooth, except for short apical spine which has ridges extending onto the cephalis. No strictures expressed externally. Cephalis subhemispherical with small circular pores; collar stricture with four collar pores internally and a vertical pore emerging from the thoracic wall which envelopes the basal cephalis. Thorax truncate-conical, abdomen inflated and fourth segment inverted truncate-conical. All three post-cephalic segments with circular to elliptical pores arranged in longitudinal rows. Wall of abdomen thickest, occasionally with area between rows of pores slightly raised. Wall of fourth segment thins distally and terminates in a ragged margin. Rare specimens show some segmental division of this fourth segment.

Measurements (based on twenty specimens from Core 96-3). Length overall, exclusive of apical horn, 225-305 $\mu$, of cephalis and thorax $60-75 \mu$; greatest width $110-165 \mu$ (majority $120-135 \mu$ ).

Remarks: This species is distinguished from spindle-shaped forms with longitudinal pores in the Miocene by its size and proportions of the thorax and abdomen.

\section{Genus PTEROCODON Ehrenberg}

\section{Pterocodon Ehrenberg, 1874b, p. 54.}

Remarks: The two species described below do not appear to be very closely related. Nor does there appear to be a very close relationship between them and the type species of Pterocodon (by monotypy), Pterocodon campana Ehrenberg, 1847b, p. 55, fig. 4 . The presence of transverse pores on the abdomen of all three species serves as the tenuous basis for this questionable generic assignment.

\section{Pterocodon (?) ampla (Brandt) (?) \\ (Plate 5, Figures 3-5)}

(?) Theocyrtis ampla Brandt, in Wetzel, 1935, p. 56, pl. 9, figs. 13-15.

(?) Theocorys unicum Lipman, in Lipman, Burtman, and Khokhlova, 1960, p. 97, pl. 12, fig. 11; Kozlova in Kozlova and Gorbovetz, 1966, p. 109 , pl. 17 , fig. 5 .

Description: Shell subcylindrical, of three segments, with relatively smooth surface and ragged distal margin. Cephalis subhemispherical with no, or a few, small, circular pores; bearing a sturdy, moderately long 
cylindro-conical horn with a roughened tip, or roughened overall. Collar stricture not very well defined externally, with a vertical pore, and with four collar pores internally. Thorax subhemispherical with regular circular to subcircular pores arranged quincuncially in transverse rows. Abdomen cylindrical with diameter equal to or less than that of thorax. Lumbar stricture may or may not be expressed externally; internally a distinct septum which varies considerably in thickness among individual specimens; thick on specimens with abdominal pores smaller or equal in size to those of the thorax, thin on specimens with abdominal pores larger. There is some tendency toward segmental division of the abdomen. Pores circular to subquadrangular, generally transversely aligned, fairly uniform in size and shape on individual specimens but varying considerably among them.

Measurements (based on fifty specimens from Core 96-3, 94-32, CC, and 94-31, CC). Length overall, exclusive of horn, 150-210 $\mu$, of cephalis and thorax 80-100 $\mu$; greatest width of thorax $60-90 \mu$.

Remarks: Some rare, less robust, slender forms have a longer, narrower apical horn and the collar stricture somewhat better defined externally (Plate 5, Figure 5). Excluded from this species is a descendant which in the later samples cooccurs. It differs in having a more inflated thorax, ridges extending from cephalis onto apical horn, and abdomen small, narrowing distally to give an overall spindle shape (Plate 5, Figure 6).

This species is distinguished from $P$. (?) tenellus by the shape of the thorax and abdomen, and the nature of the pores. It is only doubtfully synonymized with Theocyrtis ampla and Theocorys unicum because it differs in its more slender form and shorter, more robust horn. In addition it differs from T. unicum Lipman in Kozlova and Gorbovetz (1966) in having a smooth surface and from Calocyclas extensa Clark and Campbell (1942) in its more robust horn and narrower abdomen.

\section{Pterocodon (?) tenellus Foreman, new species (Plate 5, Figure 7; Plate 12, Figure 4)}

Description: Shell of three or four complete segments and sometimes a fragment of a fifth. surface smooth. Cephalis subspherical with numerous small circular pores bearing a short, bladed horn. Internally collar stricture with four collar pores, externally not expressed, with contour of cephalis and thorax merging. Thorax subcampanulate with uniform, small, circular pores, set in upwardly directed frames, arranged quincuncially in transverse and diagonal rows; lumbar stricture well defined. Abdomen barrel-shaped, equal in width to or slightly broader than the thorax, with uniform circular pores slightly larger than and arranged as on the thorax. Distally a post-lumbar stricture expressed internally with two or three closely spaced septa and externally by a slight change in contour. Abdomen below this stricture short, with uniform pores tending to be transversely aligned. Rarely a stricture with one septum separates a fifth segment; margin ragged.

Measurements (based on ten specimens from Core 96-3, 94-32, CC, and 94-31, CC). Length of cephalis and thorax, exclusive of horn, 75-90 $\mu$, of abdomen to post-lumbar stricture 55-75 $\mu$; greatest width of thorax 70-80 $\mu$, of abdomen $70-90 \mu$.

Remarks: This species is distinguished from $P$. (?) ampla (?) as described under that species.

\section{Genus RHOPALOCANIUM Ehrenberg}

Rhopalocanium Ehrenberg, 1847a, chart to p. 385. Type species (by subsequent monotypy) Rhopalocanium ornatum Ehrenberg, 1847b.

Rhopalocanium ornatum Ehrenberg

(Plate 2, Figures 8-10; Plate 12, Figure 3)

Rhopalocanium ornatum Ehrenberg, 1847b, fig. 3; 1854, pl. 36, fig. 9; 1873 , p. 256 ; 1875 , p. 82 , pl. 17 , fig. 8 ; Haeckel, 1862 , p. 336 ; 1887 , p. 1359.

[?] Rhopalocanium ornatum Ehrenberg, Bury, 1862, pl. 6, fig. 1 . Lithornithium foveolatum Ehrenberg, 1873, p. 242; 1875, p. 78 , pl. 4 , fig. 7 .

[?] Rhopalocanium pythia Haeckel, 1887, p. 1360.

? Theopera fusiformis Haeckel, in Cita, Nigrini, and Gartner, 1970, p. 403 , pl. 2 , fig. C.

Gen. et sp. indet. Riedel and Sanfilippo, 1970, p. 528, pl. 10, fig. 1.

Description: Shell spindle-shaped, of three segments, with a stout apical horn and three feet extending from the sides. Cephalis subspherical, poreless, bearing a stout cylindro-conical horn with rough pitted surface. Collar stricture internally with four collar pores, externally distinct, with a vertical pore on the proximal thorax. Thorax hemispherical, inflated, with circular to subcircular pores, sometimes with uneven margins, irregular in size and arrangement; surface smooth or slightly nodose. Abdomen inverted truncate-conical to subhemispherical with constricted aperture of basally closed; pores irregular in shape, size, and arrangement. Three sturdy feet with rough, pitted surface extend downward from the sides of the thorax and/or abdomen.

Measurements (based on twenty specimens from 94-28, CC through 94-20-4). Length overall, exclusive of horn and feet, $115-180 \mu$, of cephalis and thorax $75-90 \mu$; greatest width of thorax $75-95 \mu$.

Remarks: The older forms tend to have the abdomen open, with feet originating from the sides of the thorax and abdomen, while younger forms tend to have the abdominal aperture very constricted or closed, with feet originating primarily from the side of the abdomen.

This species has a vertical pore on the proximal thorax, as do many other theoperids. It seems, however, not to be related to forms in the Lychnocanoma auxilla - Lithochytris vespertilio lineage where this pore and its associated asymmetry is much more prominent and the thick thoracic wall envelops the basal cephalis.

\section{Genus STICHOCORYS Haeckel}

Stichocorys Haeckel, 1881, p. 438; Riedel and Sanfilippo, 1970, p. 530.

\section{Stichocorys armata (Haeckel)}

Cyrtophormis armata Haeckel, 1887, p. 1460, pl. 78, fig. 17.

Stichocorys armata (Haeckel) Riedel and Sanfilippo, 1971, pl. 2E, figs. 13-15.

\section{Stichocorys delmontensis (Campbell and Clark)}

Eucyrtidium (Eucyrtis) delmontense Campbell and Clark, 1944a, p. 56, pl. 7, figs. 19, 20.

Stichocorys delmontensis (Campbell and Clark) Sanfilippo and Riedel, 1970, p. 451, pl. 1, fig. 9; Riedel and Sanfilippo, 1971, pl. 1F, figs. 5-7; pl. $2 \mathrm{E}$, figs. $10,11$.

\section{Stichocorys diploconus (Haeckel)}

Cyrtocapsa diploconus Haeckel, 1887, p. 1513, pl. 78, fig. 6. Stichocorys diploconus (Haeckel) Sanfilippo and Riedel, 1970, p. 451, pl. 1 , figs. 31,32 .

\section{Stichocorys wolffi Haeckel}

Stichocorys wolffii Haeckel, 1887, p. 1479, pl. 80, fig. 10; Riedel, 1957a, p. 92 , pl. 4 , figs. 6 , 7; Riedel and Sanfilippo, 1971, pl. 2E, figs. 8, 9; Kling, 1971, pl. 2E.

\section{Genus THEOCORYS Haeckel}

Theocorys Haeckel, 1881, p. 434; Riedel and Sanfilippo, 1970, p. 530.

Remarks: The species below are very probably not closely related to the type species of Theocorys (designated by Campbell, 1954, p. D134) T. morchellula Rüst, 1885 , p. 308 , pl. 37 , fig. 6. T. acroria, $T$. anaclasta, and $T$. anapographa are apparently related to each other. However, $T$. (?) phyzella and $T$. (?) spongoconum do not appear to be related to each other nor to the three related species mentioned above. They are all included here for convenience until their relationships are understood.

Theocorys acroria Foreman; new species

(Plate 5, Figures 11-13; Plate 12, Figure 2)

Clathrocyclas sp. Nigrini, in Cita, Nigrini, and Gartner, 1970, p. 403, pl. 2, fig. B.

Description: Shell of three segments, similar to Theocorys anapographa except that the thorax is not as conical and has shoulders with tiny thorns or sometimes small wings. Collar stricture has four collar pores internally. Abdomen generally widens gradually and in some specimens is slightly constricted medianly. Early forms have pores considerably larger than those of the thorax, rounded or subangular; late forms have small pores proximally. Margin undifferentiated, smooth, undulating, or scalloped.

Measurements (based on ten specimens from Core 96-3, 94-30, $\mathrm{CC}$, and 94-29, CC). Length overall, exclusive of horn, 135-235 $\mu$; greatest width $125 \cdot 160 \mu$. 
Remarks: This species agrees well with the form described and illustrated by Nigrini. Because of its rarity it has been described rather broadly and includes forms which may be the precursor(s) of $T$. anaclasta as well as of $T$. anapographa. It is distinguished from the latter by the larger pores in the abdomen and from the former by the less obviously constricted abdomen.

\section{Theocorys anaclasta Riedel and Sanfilippo} (Plate 5, Figures 14, 15)

Theocorys anaclasta Riedel and Sanfilippo, 1970, p. 530, pl. 10, figs. 2, 3; Moore, 1971, pl. 2, fig. 1.

Remarks: Specimens from approximately the same levels as those described by Riedel and Sanfilippo agree well with their description and illustrations. Rare earlier forms have the abdomen with constriction less distinct. The collar stricture has four collar pores internally.

\section{Theocorys anapographa Riedel and Sanfilippo}

(Plate 5, Figures 9, 10)

Theocorys anapographa Riedel and Sanfilippo, 1970, p. 530, pl. 10, fig. 4; Moore, 1971, pl. 2, fig. 2.

Remarks: The specimens observed here agree well with those described by Riedel and Sanfilippo. The collar stricture has four collar pores internally. It is distinguished from $T$. acroria as described under that species.

\section{Theocorys (?) phyzella Foreman, new species}

(Plate 5, Figure 8; Plate 12, Figure 1)

Description: Shell of three segments. Cephalis subhemispherical, with a few small pores, bearing a slender conical horn, basally ridged. Collar stricture with four collar pores internally, well defined externally. Thorax subhemispherical with surface slightly roughened by angular frames around the pores which are small, uniform, circular, quincuncially arranged tending to longitudinal alignment; lumbar stricture well defined externally. Abdomen slightly inflated approximately equal to the thorax in length and width, or slightly larger. Pores circular to elliptical, longitudinally aligned, separated by ridges, or less regularly aligned with ridges less distinct. Distally a broad, smooth, poreless rim.

Measurements (based on twenty specimens from Core 96-3, 9432, CC, and 94-31, (CC). Length overall, exclusive of horn, $160-190 \mu$, of cephalis and thorax $85-100 \mu$, of abdomen $60-95 \mu$; greatest width of thorax $80-100 \mu$, of abdomen $85-115 \mu$.

Remarks: This species differs from Eucyrtidium embolum Ehrenberg, 1873 , p. $228 ; 1875$, pl. 10 , fig. 5 , in having a well-defined lumbar stricture and aperture with a broad, smooth rim.

\section{Theocorys (?) spongoconum (Kling)}

Eusyringium spongoconum Kling, 1971, pl. 5, fig. F.

Theocorys spongoconum (Kling) Riedel and Sanfilippo, 1971, pl. 2F, fig. 4; pl. 3C. fig. 3.

Remarks: In the material studied herein, $T$. (?) spongoconum is extremely rare or missing in the early and middle part of its reported range elsewhere.

It is here preceded by and cooccurs with a more common form, similar in all respects except that the third segment is thin, irregularly porous, instead of spongy (Plate 11, Figure 14).

\section{Genus THEOCOTYLE Riedel and Sanfilippo}

Theocotyle Riedel and Sanfilippo, 1970, p. 524.

\section{Subgenus THEOCOTYLE Riedel and Sanfilippo}

Remarks: To this nominate subgenus are assigned the species originally unquestionably included in the genus Theocotyle by Riedel and Sanfilippo and additionally Theocotyle (Theocotyle) cryptocephala (?) conica. These species are included in the lineage beginning with $T$. (T.) cryptocephala (?) nigriniae and ending with T. (T.) cryptocephala (?) conica.

\section{Theocotyle (Theocotyle) cryptocephala (?) conica Foreman, new species \\ (Plate 4, Figure 11; Plate 12, Figures 19, 20)}

Description: Shell as for late forms of Theocotyle (Theocotyle) cryptocephala cryptocephala (?) except that the abdomen is distinctly conical in shape and the vestigal wings of $T$. (T.) cryptocephala cryptocephala (?) are sometimes entirely lacking; abdominal pores may be up to twice as large as those of the thorax

Measurements (based on ten specimens from 94-22-2, 94-21-2, 94-20-4, 94-20-2). Length overall, exclusive of horn, $130-175 \mu$, of thorax $35-45 \mu$, of abdomen $85-100 \mu$; greatest width of abdomen $115-135 \mu$.

Remarks: This species in general form resembles that of Theocotyle (Theocotylissa) ficus but differs from the specimens with which it cooccurs by its smaller size, and from the early small specimens of the latter whose size might coincide with those of $T$. (T.) cryptocephala (?) conica by the more ovate form of $T$. (Theocotylissa) ficus. It differs from its ancestor $T$. (T.) cryptocephala cryptocephala (?) in the conical shape of the abdomen. This form appears to have evolved directly from $T$. (T.) cryptocephala cryptocephala (?) with the early forms of T. (T.) cryptocephala (?) conica still retaining the vestigial wings. Its relationship to $T$. (T.) venezuelensis is not understood.

\section{Theocotyle (Theocotyle) cryptocephala cryptocephala (Ehrenberg) (?)}

(Plate 4, Figures 6, 7; Plate 12, Figure 18)

[?] Eucyrtidium cryptocephalum Ehrenberg, 1873, p. 227; 1875, p. 70 , pl. 11, fig. 11 .

Theocotyle cryptocephala cryptocephala (Ehrenberg) (?) Riedel and Sanfilippo, 1970, p. 525, pl. 6, figs. 7, 8; Moore, 1971, pl. 1, fig. 12.

Remarks: In addition to the features described by Riedel and Sanfilippo, the collar stricture has internally six collar pores, the two jugular very small, and the thorax, short vestigial wings as for $T$. (T.) cryptocephala (?) nigriniae. Early specimens agree well with those described by Riedel and Sanfilippo. However, at about the level of Hole 94, Core 24, they begin to differ in that the thorax becomes more conical and the shell wall thickens. As a consequence the lumbar stricture is less distinct and the vestigial wings become less prominent.

This species is only doubtfully synonymized with E. cryptocephalum Ehrenberg because that species is described as lacking a horn.

It is distinguished from its descendant $T$. (T.) cryptocephala (?) conica as described under that species.

\section{Theocotyle (Thęocotyle) cryptocephala (?) nigriniae} Riedel and Sanfilippo

(Plate 4, Figures 1-5; Plate 12, Figure 17)

Theocorys sp. Nigrini, in Cita, Nigrini, and Gartner, 1970, p. 404, pl. 2, fig. L.

Theocotyle cryptocephala (?) nigriniae Riedel and Sanfilippo, 1970, p. 525 , pl. 6 , figs. 5,6 .

Remarks: Specimens observed here agree well with those described by Nigrini and by Riedel and Sanfilippo. In addition the collar stricture internally has six collar pores, the two jugular very small, and the thorax consistently bears vestigial wings which take the form of short, bluntly terminated, bladelike protrusions.

Forms with three short feet may be distinguished from early forms of Thyrsocyrtis rhizodon by the consistent presence of the vestigial wings on the thorax, and from Theocotyle (Theocotylissa)auctor as described under that species.

\section{Theocotyle (Theocotyle) venezuelensis Riedel and Sanfilippo} (Plate 4, Figure 12)

Theocotyle venezuelensis Riedel and Sanfilippo, 1970, p. 525, pl. 6, figs. 9, 10; pl. 7, figs. 1, 2; Moore, 1971, pl. 1, fig. 11.

Remarks: Forms comparable to the species figures as the holotype are extremely rare in the material studied, and this species is therefore not included in the tabulations or on the range chart. The few specimens observed did not have the vestigial wings present on the earlier forms of this lineage. The relationship of this form to $T$. (T.) cryptocephala (?) conica is not understood.

\section{Subgenus Theocotylissa Foreman, new subgenus}

Remarks: This subgenus is defined to include the members of the lineage extending from Theocotyle (Theocotylissa) auctor to $T$. (Theocotylissa ficus. Their relationship to $T$. (Theocotylissa (?) fimbria, if any, is not understood.

Type species: Theocotyle (Theocotylissa) ficus (Ehrenberg) 
Theocotyle (Theocotylissa) alpha Foreman, new species (Plate 4, Figures 13-15; Plate 12, Figure 16)

Description: Cephalis subspherical, with no or a few pores, and bearing a short, smooth or slightly ridged, conical horn with a blunt or uneven tip. Collar stricture not expressed externally, internally with six collar pores, the two jugular pores very small. Thorax conical and abdomen considerably longer, barrel-shaped, or subcylindrical. Thoracic and abdominal wall thick, with lumbar stricture not at all or only very slightly expressed externally. Pores small and circular on the thorax; larger, uniform, circular to subcircular, quincuncially arranged in vertical rows on the abdomen. The thick, poreless, abdominal rim generally terminates in three short, triangular feet with blunt or indented tips, frequently with a tiny outward thorn as in Thyrsocyrtis rhizodon. Sometimes the feet are expressed only as three shallow undulations.

Measurements (based on fifteen specimens from 94-31, CC and Core 94-30). Length overall, exclusive of horn and feet, $140-200 \mu$, of thorax $40-50 \mu$, of abdomen $80-135 \mu$; greatest width of thorax $80-100 \mu$, of abdomen $115-145 \mu$.

Remarks: This species is distinguished from $T$. (Theocotylissa) auc$t o r$, its ancestor, as described under that species, and from $T$. (Theocotylissa) ficus by its three feet.

\section{Theocotyle (Theocotylissa) auctor Foreman, new species} (Plate 4, Figures 8-10; Plate 12, Figure 13)

Description: Cephalis subspherical with almost no to rather numerous small circular pores, bearing a stout conical horn approximately equal in length to the thorax (rarely in early forms more slender, short). Collar and lumbar stricture well defined externally, internally collar stricture with four collar pores. Thorax campanulate, inflated, with circular to subcircular uniform pores; surface rough. Abdomen generally longer than the thorax, barrel-shaped, generally equal to or greater in width than the thorax; some late specimens more inflated. Pores may be equal to or slightly larger in size than those of the thorax, and tend to be vertically aligned; occasionally pores more irregular in size and arrangement; surface generally smooth. Three thin feet extend smoothly from the poreless abdominal rim; short, triangular, with truncate or rarely pointed tip, sometimes with indentation(s) at the margin to form two or three points, similar to the irregularity of the tip of the feet of Thyrsocyrtis rhizodon.

Measurements (based on twenty-five specimens from Core 96-3, 94-32, CC, and 94-31, CC). Length overall, exclusive of horn and feet, $120-225 \mu$ (majority $150-180 \mu$ ), of thorax $45-70 \mu$, of abdomen $40-125 \mu$ (majority $60-95 \mu$ ); greatest width of thorax $80-115 \mu$, of abdomen $80-125 \mu$.

Remarks: This species differs from early and late forms of Thyrsocyrtis rhizodon in that the feet, while frequently similar in outline, are thin rather than thickened, and more cylindrical, as in $T$, rhizodon. The horn is almost always stout and long, while the horn of $T$. rhizodon tends to be more slender and shorter, and there is less differential in the size of the pores between thorax and abdomen. They do not cooccur.

Theocotyle (Theocotylissa) auctor is apparently the ancestor from which two lineages branch. It is distinguished from its immediate descendant, $T$. (Theocotylissa) alpha, by its smaller abdomen and larger horn. The lineage connecting $T$. (Theocotylissa) auctor and its probable descendant. Theocotyle (Theocotyle) cryptocephala (?) nigriniae, is less clearly evident. It is distinguished from the latter by the lack of vestigial wings and the generally inflated abdomen.

\section{Theocotyle (Theocotylissa) ficus (Ehrenberg)}

(Plate 4, Figures 16-20)

Eucyrtidium ficus Ehrenberg, 1873, p. 228; 1875, p. 70, pl. 11, fig. 19. Anthocyrtis? ficus (Ehrenberg), Bütschli, 1882, pl. 31, fig. 7 .

Theoconus ficus (Ehrenberg) Haeckel, 1887, p. 1403.

Theocotyle (?) ficus (Ehrenberg) Riedel and Sanfilippo, 1970, p. 525, pl. 7, figs. 3-5.

Description: Thick shell, subovate to broadly conical in form, with collar and lumbar stricture expressed externally not at all or only very slightly. Cephalis subspherical with few or no pores, and bearing a short, stout, conical horn sometimes associated with a cluster of sharp spines. Later specimens tend to have a longer, more slender horn. Internally the collar stricture with six collar pores, the jugular pores larger on later specimens. Thorax subcampanulate to conical, with circular to subcircular pores, less evenly distributed, and smaller than those of the abdomen.
Abdomen large, inflated or truncate-conical, rarely subcylindrical. Pores circular to subcircular, quincuncially arranged in vertical rows with surface smooth or roughened with tiny thorns or angular pore frames. Early specimens are generally more ovate in form and have a thick, smooth, rarely wavy rim, which becomes less prominent in younger specimens, until in the youngest forms the rim turns inward and is not evident in the lateral view.

Measurements (based on thirty specimens from numerous levels from 94-31, CC through 94-17-4). Length overall, exclusive of horn, $150-240 \mu$, of thorax $35-45 \mu$, of abdomen $85-165 \mu$; greatest width of thorax 85-100 $\mu$, of abdomen $125-240 \mu$.

Remarks: T. (Theocotylissa) ficus is described very broadly, and although the early and late forms differ considerably, no satisfactory criteria for dividing this species could be found. The description has been emended somewhat from that given by Riedel and Sanfilippo (1970) to include early forms not present in the Leg 4 material on which their description is based.

\section{Theocotyle (Theocotylissa) (?) fimbria Foreman, new species} (Plate 5, Figures 1, 2; Plate 12, Figure 21)

Description: Shell conical, very like late forms of $T$. (Theocotylissa) ficus except that the shell wall is generally thinner with larger abdominal pores and instead of a smooth rim, the porous shell wall extends to form a fluted rim from which extend a variable number of irregularly distributed, very short, pointed, ridged feet or teeth. Late forms have the feet very reduced or entirely lacking. Collar stricture with six collar pores, the two jugular very small.

Measu rements (based on ten specimens from 94-31, CC and Core 94-30). Length overall, exclusive of horn, $170-220 \mu$, of thorax

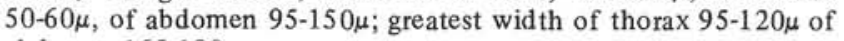
abdomen $165-190 \mu$.

Remarks: Late forms with reduced feet or feet entirely lacking may be distinguised from the forms of Theocotyle (Theocotylissa) ficus with which they cooccur by their thinner shell, broader conical form, and lack of a smooth apertural rim.

Description: Shell conical, very like late forms of $T$. (Theocotylissa) ficus except that the shell wall is generally thinner with larger abdominal pores and instead of a smooth rim, the porous shell wall extends to form a fluted rim from which extend a variable number of irregularly distributed, very short, pointed, ridged feet or teeth. Late forms have the feet very reduced or entirely lacking. Collar stricture with six collar pores, the two jugular very small.

Measurements (based on ten specimens from 94-31, CC and Core 94-30). Length overall, exclusive of horn, 170-220 $\mu$, of thorax $50-60 \mu$, of abdomen $95-150 \mu$; greatest width of thorax $95-120 \mu$, of abdomen $165-190 \mu$.

Remarks: Late forms with reduced feet or feet entirely lacking may be distinguished from the forms of Theocotyle (Theocotylissa) ficus with which they cooccur by their thinner shell, broader conical form, and lack of a smooth apertural rim.

\section{Genus THYROSOCYRTIS Ehrenberg}

Thyrsocyrtis Ehrenberg, 1847b, p. 54.

\section{Thyrsocyrtis bromia Ehrenberg}

Thyrsocyrtis bromia Ehrenberg, 1873, p. 260; 1875, p. 84, pl. 12, fig. 2; Riedel and Sanfilippo, 1970, p. 526; 1971, pl. 8, fig. 6; Moore, 1971, pl. 5, figs. 1-3.

\section{Thyrsocyrtis hirsuta hirsuta (Krasheninnikov)}

(Plate 3, Figures 3-8; Plate 12, Figure 15)

Podocyrtis hirsutus Krasheninnikov, 1960, p. 300, pl. 3, fig. 16.

Thyrsocyrtis hirsuta hirsuta (Krasheninnikov) Riedel and Sanfilippo, 1970 , p. 526, pl. 7, fig. 9.

Description: Thyrsocyrtis hirsuta hirsuta is here emended to include only forms with pores of the abdomen equal in size to or only slightly larger than those of the thorax. The shell may be robust or, as in the forms described by Riedel and Sanfilippo, not very robust. The three feet are very variable in length, straight or slightly divergent, smooth, except for a roughened tip, and depend evenly from the poreless marginal rim of the abdomen. Typically they are robust, thickened medianly with convexity inward, and rare early specimens may have a few pores as in $T$. tarsipes. In addition the collar stricture has internally six collar pores, the two jugular pores very small. 
Measurements (based on twenty specimens from 94-31, CC, 9430, CC, 94-29, CC, Core 94-28, 94-27, CC, and 94-22-1). Length overall, exclusive of horn and feet, $110-180 \mu$; greatest width of abdomen $75-130 \mu$ (majority $95-115 \mu$ ).

Remarks: This species is distinguished from $T$. hirsuta tensa as described under that species.

\section{Thyrsocyrtis hirsuta robusta Riedel and Sanfilippo} (Plate 3, Figure 17)

Thyrsocyrtis hirsuta robusta Riedel and Sanfilippo 1970, p. 526, pl. 8, fig. 1.

Description: $T$. hirsuta robusta is here restricted to robust forms very similar to the holotype, i.e. with thorax hemispherical, lumbar stricture well defined, and thorax and abdomen very rough. Feet depend with convexity inward or straight.

Measurements (based on seven specimens from Core 94-25, 94 23-2, and 94-22-4). Length overall, exclusive of horn and feet, 160 $222 \mathrm{u}$.

Remarks: Thyrsocyrtis hirsuta robusta restricted as described above has a rather short range. It is distinguished from $T$. hirsuta hirsuta and $T$. hirsuta tensa by its rough thorax and abdomen and distinctly hemispherical thorax. It may eventually be synonymized with $T$. hirsuta hirsuta, but this step is not now taken pending examination of material from the type locality.

\section{Thyrsocyrtis hirsuta tensa Foreman, new subspecies}

(Plate 3, Figures 13-16; Plate 12, Figure 8)

Thyrsocyrtis hirsuta hirsuta (Krasheninnikov) Riedel and Sanfilippo, 1970 , p. 526 , pl. 7 , fig. 8 .

Description: Shell similar to that of Thyrsocyrtis hirsuta hirsuta except that the pores of the abdomen are markedly larger than those of the thorax and the abdomen is generally inflated. Feet may depend straight or be curved with convexity inward.

Measurements (based on forty specimens from Cores 94-28 and 94-27, 94-26-5, 94-24-3, Core 94-22, and 94-21-2). Length overall, exclusive of horn and feet, $125-200 \mu$; greatest width of abdomen $85-140 \mu$.

Remarks: When the feet turn and are curved with convexity outward this form passes to $T$. triacantha. $T$. hirsuta tensa evidently evolved from $T$. hirsuta hirsuta in the late Early Eocene. They cooccur in the early Middle Eocene until $T$. hirsuta hirsuta becomes extinct and $T$. hirsuta tensa evolves into $T$. triacantha.

$T$. hirsuta tensa includes, as does $T$. hirsuta hirsuta, a great variety of forms, some robust and others more delicate. The very delicate late forms with thin, spindly legs and thin shell with relatively smooth surface have only four collar pores. These features may serve later as the basis for separation into a distinct subspecies.

$T$. hirsuta tensa is distinguished from $T$. hirsuta robusta as described under that species.

\section{Thyrsocyrtis rhizodon Ehrenberg}

(Plate 3, Figures 1, 2)

Thyrsocyrtis rhizodon Ehrenberg, 1873, p. 262; 1875, p. 94, pl. 12, fig. 1;

Riedel and Sanfilippo, 1970 , p. 525, pl. 7, figs. 6, 7.

Remarks: Specimens observed here agree well with those described by Riedel and Sanfilippo from material of comparable age. In addition the earlier forms observed here have short triangular feet with an outwardly directed thorn, and pores of the abdomen only slightly larger than those of the thorax. All forms have six collar pores, the later specimens from the Upper Eocene, with jugular pores very small.

The origin of $T$. rhizodon is obscure. It may have arisen from $T$. hirsuta hirsuta.

This species may be distinguished from Theocotyle (T.) cryptocephala (?) nigriniae as described under that species, and from $T$. hirsuta hirsuta by the collar pores and feet which when short have an outwardly directed thorn and when longer are thick and straight.

\section{Thyrsocyrtis tarsipes Foreman, new species}

(Plate 3, Figure 9; Plate 12, Figure 14)

Description: Shell of three segments with three porous feet. Cephalis subspherical, with numerous circular to subcircular pores, and bearing a slender, smooth, conical horn, very variable in length. Collar and lumbar strictures well defined externally; internally collar stricture with four collar pores. Thorax campanulate, slightly inflated, with generally regular, circular to subcircular pores, a rough surface, and tiny vestigial wings. Abdomen smooth, slightly inflated, triangular in cross section, shorter than, and of approximately the same width as, the thorax; pores generally irregular in size and shape, equal in size to twice as large as, and generally more widely spaced than, those of the thorax. Three feet, with irregular pores generally throughout their length and with a roughened tip, depend smoothly from the poreless abdominal rim.

Measurements (based on fifteen specimens from Core 96-3). Length overall, exclusive of horn and feet, 113-150 $\mu$, of thorax $55-65 \mu$, of abdomen $35-55 \mu$; greatest width of thorax $85-95 \mu$, of abdomen $75-100 \mu$.

Remarks: $T$. tarsipes differs from $T$. hirsuta hirsuta in its generally smaller size, cephalis with pores and a slender horn, vestigial wings on the thorax, and porous feet. It differs from Podocyrtis grata Kozlova, in Kozlova and Gorbovetz, 1966, p. 107, pl. 17, fig. 3, in having porous feet.

\section{Thyrsocyrtis tetracantha (Ehrenberg)}

Podocyrtis tetracantha Ehrenberg, 1873, p. 254; 1875, p. 82, pl. 13, fig. 2.

Thyrsocyrtis tetracantha (Ehrenberg) Riedel and Sanfilippo, 1970, p. 527; Moore, 1971, pl. 4, fig. 3.

\section{Thyrsocyrtis triacantha (Ehrenberg) (Plate 12, Figures 9-11)}

Podocyrtis triacantha Ehrenberg, 1873, p. 254; 1875, p. 82, pl. 13, fig. 4. Thyrsocyrtis triacantha (Ehrenberg) Riedel and Sanfilippo, 1970, p. 526, pl. 8, figs. 2, 3; 1971, pl. 3C, fig. 7.

Remarks: Specimens observed here agree well with the broad species described and illustrated by Riedel and Sanfilippo.

This species apparently evolved from $T$. hirsuta tensa with which it cooccurs for a short time, and from which early forms are distinguished by the feet which curve with convexity outward.

Excluded is an early form (Plate 3, Figures 18, 19; Plate 12, Figure 7) with a less robust abdomen, relatively smaller pores, and slender irregularly porous feet which in later specimens are less porous and tend to be three-bladed (Plate 12, Figure 12). These forms may be the precursors of the one illustrated by Riedel and Sanfilippo (1970, pl. 8, fig. 4) and thus they may represent a distinct separate lineage.

\section{INCERTAE SEDIS}

\section{Genus LOPHOCYRTIS Haeckel}

Lophocyrtis Haeckel, 1887, p. 1410.

\section{Lophocyrtis biaurita (Ehrenberg)}

(Plate 8, Figures 23-26)

Eucyrtidium biauritum Ehrenberg, 1873, p. 226; 1875, p. 70, pl. 10, figs. 7, 8; Bütschli, 1881 , p. 530 , pl. 33 , figs. 38a-f.

[?] Eucyrtidium bicorne Ehrenberg, 1873, p. 226; 1875, p. 70, pl. 11 , fig. 7.

Lophocyrtis biaurita (Ehrenberg), Haeckel, 1887, p. 1411; Cita, Nigrini, and Gartner, 1969, p. 404, pl. 2, figs. I-K.

Remarks: Bütschli (1881, p. 530) considered this species and $E$. bicorne Ehrenberg to be unique, and suggested that they might perhaps belong to his "Lithomitragruppe" in which he listed as constituent species forms which now would be included in the Artostrobiidae. Riedel (1967, p. 149), in his definition of the family Artostrobiidae, named $L$. biaurita as one of its constituent species.

It is here not considered as an artostrobiid. Nor is it considered likely that $L$. biaurita is closely related to the type species of Lophocyrtis. Eucyrtidium stephanophorum Ehrenberg, 1873, p. 233; 1875, pl. 8, fig. 14 (designated by Campbell, 1954, p. D134). The generic assignment remains unchanged only as a matter of convenience until its relationship to other forms is better understood.

\section{REFERENCES}

Aliev, Kh. Sh., 1965. Radiolarians of the Lower Cretaceous deposits of northeastern Azerbaidzhan and their stratigraphic significance. Akad. Nauk Azerb. SSR, Inst. Geol. Akad. I.M. Gubkina. 1.

Brandt, R. In Wetzel, O., 1935. Die Mikropalaeontologie des Heiligenhafener Kieseltones (Ober-Ë̈zan). Niedersaechs. Geol. Verhandl. Jahresber. 27, 41 . 
Burma, B.H., 1959. On the status of Theocampe Haeckel, and certain similar genera. Micropaleontology. 5(3), 325.

Bury, P.S., 1862. Figures of remarkable forms of Polycystins, or allied organisms, in the Barbados chalk deposit. London, (W. Weldon).

Bütschli, O., 1881. Beiträge zur Kenntnis der Radiolarienskelette, insbesondere der der Cyrtida. Z. Wiss. Zool. 36, 485. 1882. Radiolaria. In Klassen und Ordnungen des Thier-Reichs, H.G. Bronn (Ed.). 1, pt. 1, 332.

Campbell, A. S., 1951. New genera and subgenera of Radiolaria. J. Paleontol. 25 (4), 527.

1954. Radiolaria In Treatise on Invertebrate Paleontology, R. C. Moore (Ed.). Univ. Kansas Press and Geol. Soc. Am., pt. D, Protista 3,11.

Campbell, A.S. and Clark, B.L., 1944a. Radiolaria from Upper Cretaceous of middle California. Geol. Soc. Am., Spec. Paper 57. $61 \mathrm{p}$.

1944b. Miocene radiolarian faunas from Southern California. Geol. Soc. Am., Spec. Paper 51. 76 p.

Cita, M.B., Nigrini, C., and Gartner, S., 1970. Biostratigraphy. In Peterson, M.N.A., Edgar, N.T. et al., 1970. Initial Reports of the Deep Sea Drilling Project, Volume II. Washington (U.S. Government Printing Office). 391.

Clark, B.L. and Campbell, A.S., 1942. Eocene radiolarian faunas from the Mt. Diablo area, California. Geol. Soc. Am., Spec. Paper 39. $112 \mathrm{p}$.

Ehrenberg, C.G., 1838. Über die Bildung der Kreidefelsen und des Kreidemergels durch unsichtbare Organismen. Abh. Kgl. Akad. Wiss. Berlin. Jahre 1838, 59.

1847a. Über eine halibiolithische, von Herrn R. Schomburgk entdeckte, vorherrschend aus mikroskopischen Polycystinen gebildete, Gebirgsmasse von Barbados. Ber. Kgl. Preuss. Akad. Wiss. Berlin. Jahre $1846,382$.

1847b. Über die mikroskopischen kieselschaligen Polycystinen als mächtige Gebirgsmasse von Barbados und über das Verhältniss der aus mehr als 300 neuen Arten bestehenden ganz eigenthümlichen Formengruppe jener Felsmasse zu den jetzt lebenden Thieren und zur Kreidebildung. Eine neue Anregung zur Erforschung des Erdlebens. Ber. Kgl. Preuss. Akad. Wiss. Berlin. Jahre 1847, 40.

1854. Mikrogeologie. Leipzig (Voss). 374 p.; Fortsetzung (1856), $88 \mathrm{p}$.

, 1860. Uber den Tiefgrund des Stillen Oceans zwischen Californien und den Sandwich-Inseln aus bis $15600^{\prime}$ Tiefe nach Lieut. Brooke. Monatsber. Kgl. Preuss. Akad. Wiss. Berlin. Jahre 1860, 819.

1872a. Mikrogeologische Studien als Zusammenfassung der Beobachtungen des kleinsten Lebens der Meeres Tiefgründe aller Zonen und dessen geologischen Einfluss. Monatsber. Kgl. Preuss. Akad. Wiss. Berlin. Jahre 1872, 265. $1872 \mathrm{~b}$. Mikrogeologische Studien über das kleinste Leben der Meeres-Tiefgründe aller Zonen und dessen geologischen Einfluss. Abh. Kgl. Akad. Wiss. Berlin. Jahre 1872, 131.

1873. Grössere Felsproben des PolycystinenMergels von Barbados mit weiteren Erläuterungen. Monatsber. Kgl. Preuss. Akad. Wiss. Berlin. Jahre 1873, 213.

1875. Fortsetzung der mikrogeologischen Studien als Gesammt-Uebersicht der mikroskpischen Paläontologie gleichartig analysirter Gebirgsarten der Erde, mit specieller Rücksicht auf den Polycystinen-Mergel von Barbados. Abh. Kgl. Akad. Wiss. Berlin. Jahre 1875, 1.

Foreman, H.P., 1966. Two Cretaceous radiolarian genera. Micropaleontology. 12(3), 355.
1968. Upper Maestrichtian Radiolaria of California.

Palaeontol. Assoc., London, Spec. Paper 3, 1.

1971. Cretaceous Radiolaria. In Winterer, E.L., Riedel, W.R. et al., 1971. Initial Reports of the Deep Sea Drilling Project, Volume VII. Washington (U.S. Government Printing Office). 1673.

Goll, R.M., 1968. Classification and phylogeny of Cenozoic Trissocyclidae (Radiolaria) in the Pacific and Caribbean Basins. Pt. I. J. Paleontol. 42(6), 1409.

Haeckel, E. 1860. Fernere Abbildungen und Diagnosen neuer Gattungen und Arten von lebenden Radiolarien des Mittelmeeres. Monatsber. Kgl. Preuss. Akad. Wiss. Berlin. Jahre 1860,835 .

1862. Die Radiolarien. (Rhizopoda Radiaria). Berlin (Reimer). 572 p.

1881. Entwurf eines Radiolarien-Systems auf Grund von Studien der Challenger-Radiolarien. Jena. Z. Med. Naturwiss. 15 (New Ser. 8(3)), 418.

1887. Report on the Radiolaria collected by H.M.S. Challenger during the years 1873-76. Rept. Voyage Challenger, Zool. 18.1803 p.

Harting, P., 1863. Bijdrage tot de kennis der mikroskopische fauna en flora van de Banda-Zee. Verh. Koninkl. Akad. Wetenschap. Amsterdam. 10, 1.

Kling, S.A., 1971. Radiolaria. In Fischer, A.G., Heezen, B.C., et al., 1971. Initial Reports of the Deep Sea Drilling Project, Volume VI. Washington (U.S. Government Printing Office). 1069.

Kozlova, G.E. and Gorbovetz, A.N., 1966. Radiolaria of the Upper Cretaceous and Upper Eocene deposits of the West Siberian Lowland. Tr. Vses. Nauch.-Issled. Geol.-Razv. Inst. $248,1$.

Krasheninnikov, V.A., 1960. Some Radiolarians of the Lower and Middle Eocene of the Western Pre-Caucasus. Min. Geol. i Okhr. Nedr SSSR, Vses. Nauch.-Issled. Geol. Neft. Inst. 16, 271.

Lipman, R. Kh., Burtman, E. S., and Khokhlova, I. A., 1960. Stratigraphy and fauna of the Paleogene deposits in the Western Siberian Lowland. Min. Geol. i Okhr. Nedr SSSR, Tr. Vses. Nauch.-Issled. Geol. Inst., new ser. 28, 69-98, 154-172.

Moore, T.C., Jr., 1971. Radiolaria. In Tracey, J.I., Jr., Sutton, G.H., et al., 1971. Initial Reports of the Deep Sea Drilling Project, Volume VIII. Washington (U.S. Government Printing Office). 727.

Nakaseko, K., 1963. Neogene Cyrtoidea (Radiolaria) from the Isozaki Formation in Ibaraki Prefecture, Japan. Osaka Univ. Sci. Rept., 12(2), 165.

Pessagno, E.A., Jr. 1963. Upper Cretaceous radiolaria from Puerto Rico. Micropaleontology. 9(2), 197.

1969. The Neosciadiocapsidae, a new family of Upper Cretaceous Radiolaria. Bull. Am. Paleontol. 56(253), 377. 1971. Jurassic and Cretaceous Hagiastridae from the Blake-Bahama Basin (Site 5A, JOIDES Leg I) and the Great Valley sequence, California Coast Ranges. Bull. Am. Paleontol. 60(264), 1 .

, In press. Pseudoaulophacidae Riedel from the Cretaceous and the Blake-Bahama Basin. Bull. Am. Paleontol.

Riedel, W.R. 1957a. Radiolaria: a preliminary stratigraphy. Rept. Swedish Deep-Sea Exped. 6(3), 59.

1957b. Eocene Radiolaria. U.S. Geol. Survey Prof. Paper 280G, 257.

1958. Radiolaria in antarctic sediments. Rept. B.A.N.Z. Antarct. Res. Exped., Ser. B, 6, Pt. 10, 217. 1959. Oligocene and Lower Miocene Radiolaria in tropical Pacific sediments. Micropaleontology. 5(3), 285. 
1967a. Some new families of Radiolaria. Proc. Geol. Soc. London. 1640, 148.

1967b. Subclass Radiolaria. In The Fossil Record, W.B. Harland et al. (Eds.) London (Geol. Soc. London). 291. Riedel, W.R. and Sanfilippo, A., 1970. Radiolaria. In Bader, R.G., Gerard, R.D. et al. 1970. Initial Reports of the Deep Sea Drilling Project, Volume IV. Washington (U.S. Government Printing Office). 503.

1971. Cenozoic Radiolaria from the western tropical

Pacific. In Winterer, E.L., Riedel, W.R. et al. 1971. Initial Reports of the Deep Sea Drilling Project, Volume VII. Washington (U.S. Government Printing Office). 1539.

Rüst, D., 1885. Beiträge zur Kenntniss der fossilen Radiolarien aus Gesteinen des Jura. Palaeontographica. 31, Ser. 3 (7), 273.

Sanfilippo, A. and Riedel, W.R., 1970. Post-Eocene "closed" theoperid radiolarians. Micropaleontology. 16(4), 446.

Tan Sin Hok, 1927. Over de samenstelling en het onstaan van krijt-en mergelgesteenten van de Molukken. Jaarb. Mijnw. Ned.-Oost-Indië, Jaarg. 1926, Verhand., Pt. 3, 5.

White, M.P., 1928. Some index foraminifera of the Tampico Embayment area of Mexico. J. Paleontol. 2(4), 280.

Manuscript submitted September, 1971.

\section{EXPLANATION OF PLATES}

The synchronopticon, comprising Plates $1-8$, is intended to show evolutionary changes within a species, and from species to species when illustrations in vertical rows are considered, and species that occur together in one level when illustrations in horizontal rows are considered.
The five levels selected for illustration are in order from youngest to oldest:

94-22-4(42-44) Theocampe mongolfieri Zone

94-28-5(43-45) Phormocyrtis striata striata Zone

94-30-2(114-116) Buryella clinata Zone

96-3-5(42-44) Bekoma bidarfensis Zone

86-8(CC) Unzoned interval

It was not always possible to find a specimen suitable for photographing from these levels. In such a case, a specimen from a nearby level was chosen and its level given in the plate descriptions. Between 94-30-2(114-116) and 96-3-5(42-44) some extinctions and evolutionary changes took place that it seems desirable to record. Illustrations from an intermediate sample, 94-31(cc), are placed at a raised level from that used for the illustrations for 96-3-5(42-44) to indicate this marked difference in level visually. In order to save plate space, when it is perfectly obvious that two lineages are not related, a new evolutionary lineage has been illustrated above a completed older one rather than placing it in a separate vertical column.

Plates 9-12 illustrate at a larger magnification than is possible in the synchronopticon all the new species described and some previously described species for which it seems useful to have additional illustrations. Two or more illustrations of one species may illustrate variations of a form at the same or a different level or two different views if this is judged useful for identification. For species with illustrations from more than one level the illustration with the lowest number represents the oldest form and progressively higher numbers, younger forms.

Plate 13 illustrates Cretaceous forms.

Magnifications for all illustrations are given at the head of the plate descriptions.
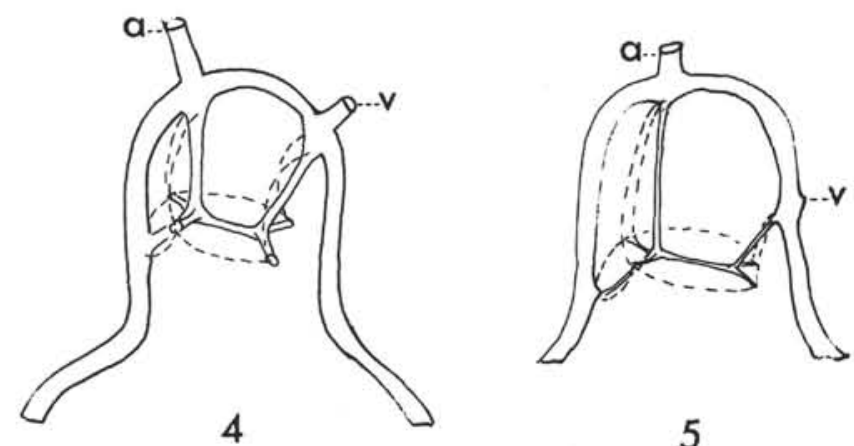
5

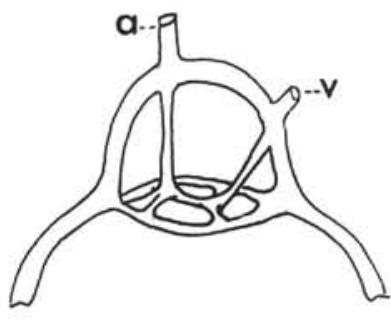

6

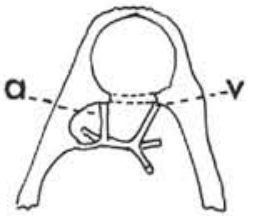

7

Figures 4-7. Right lateral view of the cephalis of: 4. Bekoma campechensis; 5. Orbula comitata; 6. Bekoma (?) demissa; " $a$ ", apical spine or horm; " $v$ ", vertical bar or horn. 



\section{PLATE 1}

(Magnification: Figures 1-11, 17-19, X100; Figures 12-16, X108)

Figures 1-5 Calocycloma ampulla (Ehrenberg)

1. USNM 178891, D22/0.

2. USNM $178845, \mathrm{U} 11 / 2$.

3. USNM 178814, B28/0.

4. USNM 178815, M32/0.

5. USNM 178766, X38/0.

Figure $6 \quad$ Calocycloma sp.

$$
\text { USNM 178816, T14/3. }
$$

Figures 7, 9, 10 Calocycloma castum (Haeckel)

7. USNM 178846, M36/0.

9. USNM 178847, D13/2.

10. USNM $178818, \mathrm{~T} 44 / 0$.

Figure $8 \quad$ Calocycloma sp. aff. C. castum (Haeckel)

94-30-1(33-35), USNM 178817, F31/4.

Figure $11 \quad$ Calocycloma sp.

USNM 178767, E43/3.

Figures 12-15 Calocyclas hispida (Ehrenberg)

12. USNM 178892, V23/2.

13. 94-26-5(43-45), USNM 178849, S26/4.

14. $94-26-5(43-45)$, USNM $178848, \mathrm{~N} 24 / 3$.

15. USNM $178819, \mathrm{~J} 40 / 4$.

Figure $16 \quad$ Calocyclas sp.

USNM 178768, Q13/1.

Figure $17 \quad$ Lychnocanoma bellum (Clark and Campbell) 94-26-5(43-45), USNM 178850, N15/3.

Figure 18 Lychnocanoma sp. aff. L. bellum (Clark and Campbell) 96-3-3(42-44), USNM 178769, 032/2.

Figure 19 Lychnocanoma anacolum Foreman n. sp. USNM 178723, T37/3. 


\section{PLATE 1}
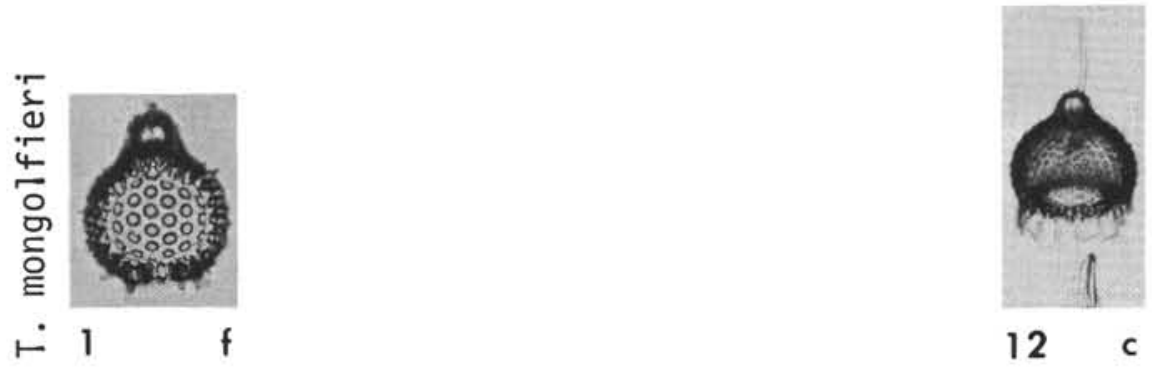

12 c
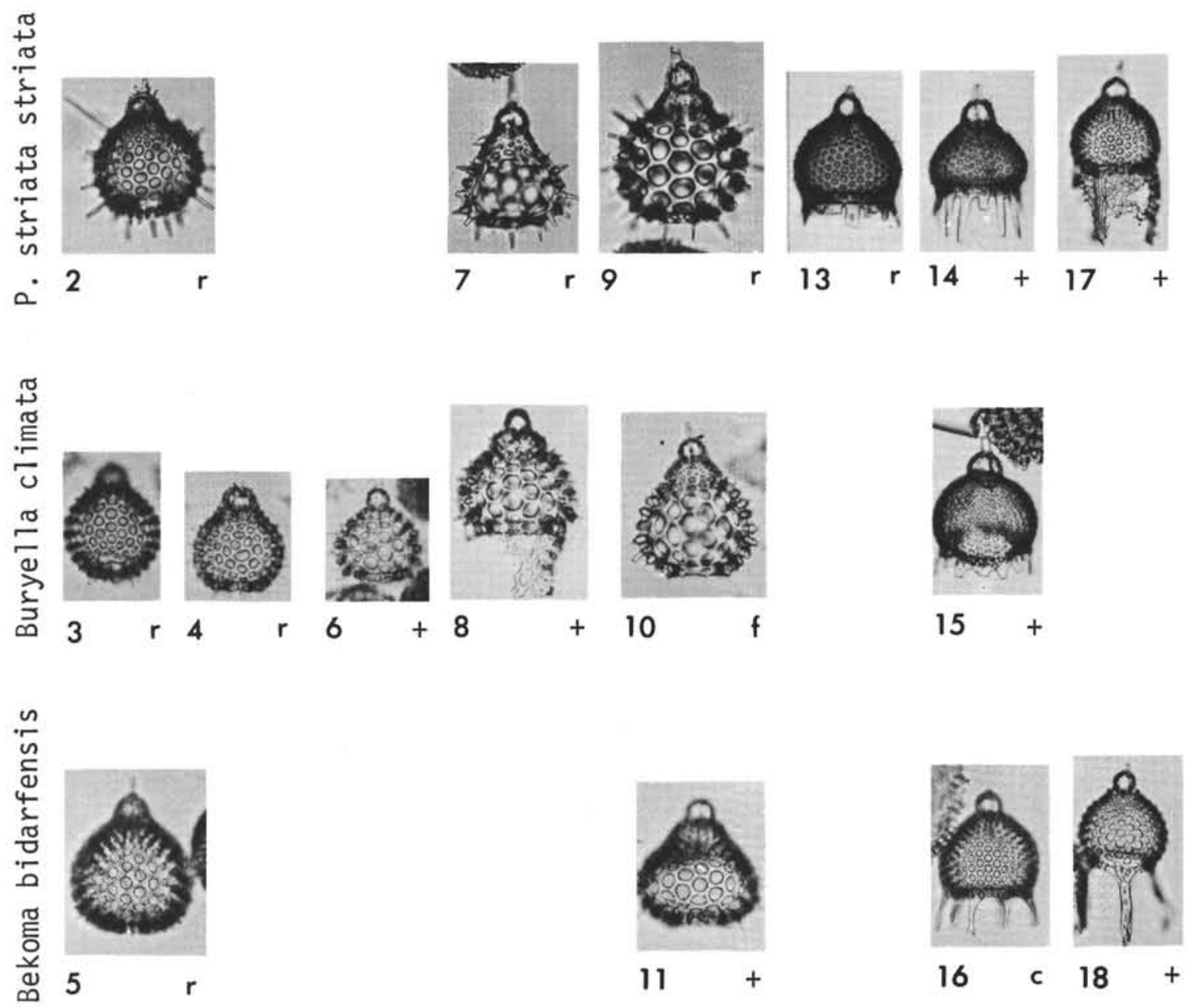

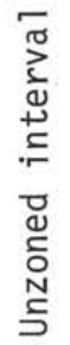

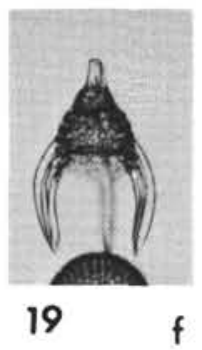


PLATE 2

(Magnification $\times 108$ )

Figure 1 Lychnocanoma babylonis (Clark and Campbell) group

USNM 178770, D12/3.

Figures 2, $3 \quad$ Lithochytris vespertilio Ehrenberg

2. USNM $178893, \mathrm{D} 30 / 2$.

3. USNM $178894, \mathrm{C} 30 / 0$.

Figures 4, $5 \quad$ Lithochytris archaea Riedel and Sanfilippo

4. USNM 178851, F13/4.

5. USNM 178820, R35/0.

Figure 6 Lychnocanoma auxilla Foreman n. sp.

USNM 178771, D30/0.

Figure 7 Dictyoceras caia Foreman n. sp.

USNM 178724, X17/2.

Figures 8-10 Rhopalocanium ornatum Ehrenberg
8. USNM 178895 , U43/4.
9. USNM 178852, D30/1.
10. $94-26-5(43-45)$, USNM $178853, \mathrm{~V} 28 / 0$.

Figures 11, 12 Clathrocycloma spp.

11. USNM 178772,029/4.

12. USNM $178723, \mathrm{~K} 29 / 3$.

Figure $13 \quad$ Clathrocycloma parcum Foreman n. sp. 86-8-4(119-121), USNM 178725, K47/0.

Figure 14 Clathrocycloma sp. aff. C. capitaneum Foreman USNM 178726, A30/0.

Figure 15 Clathrocycloma capitaneum Foreman n. sp. USNM 178727, D18/1. 


\section{PLATE 2}
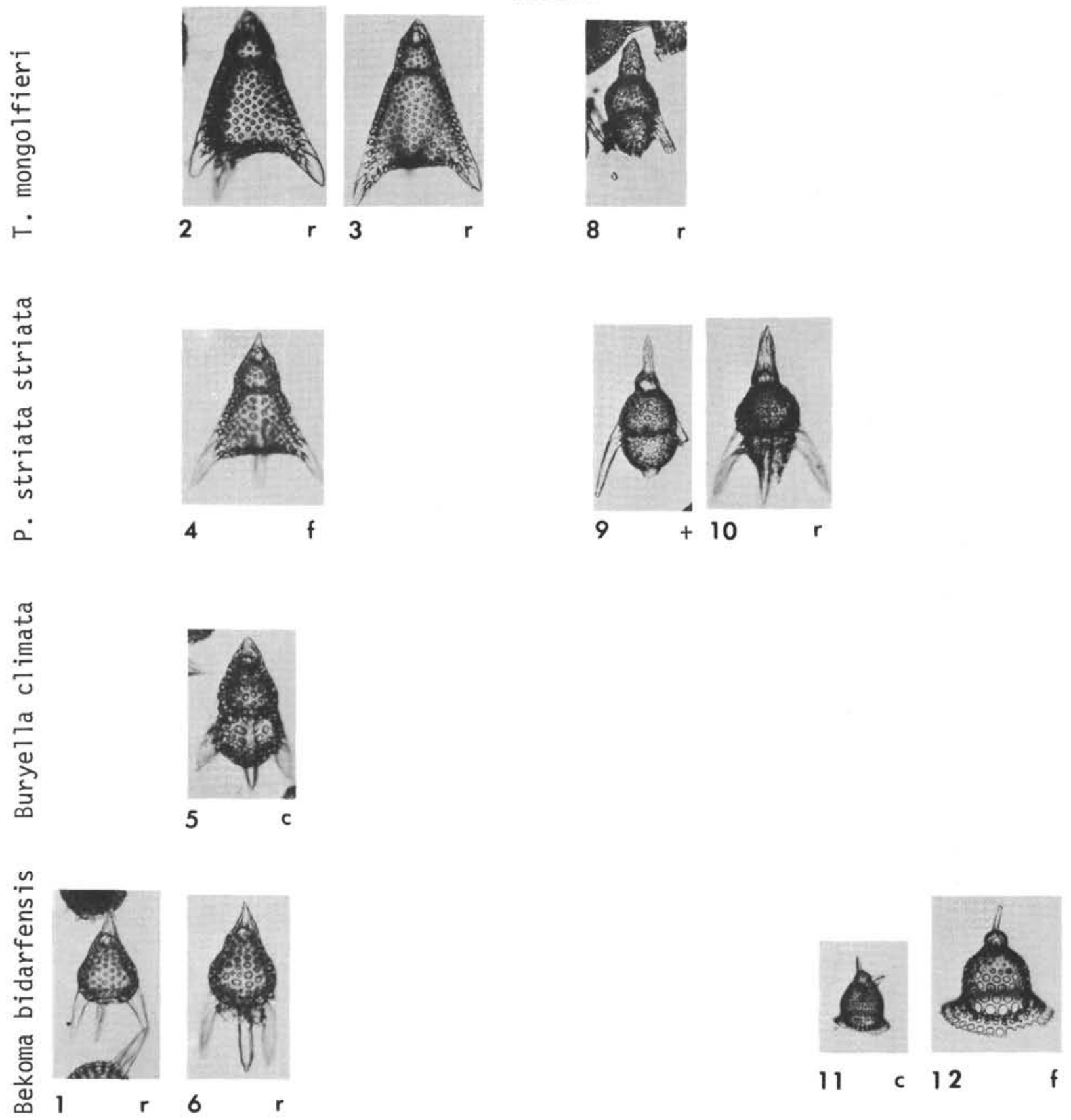

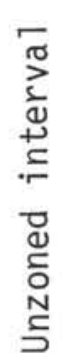
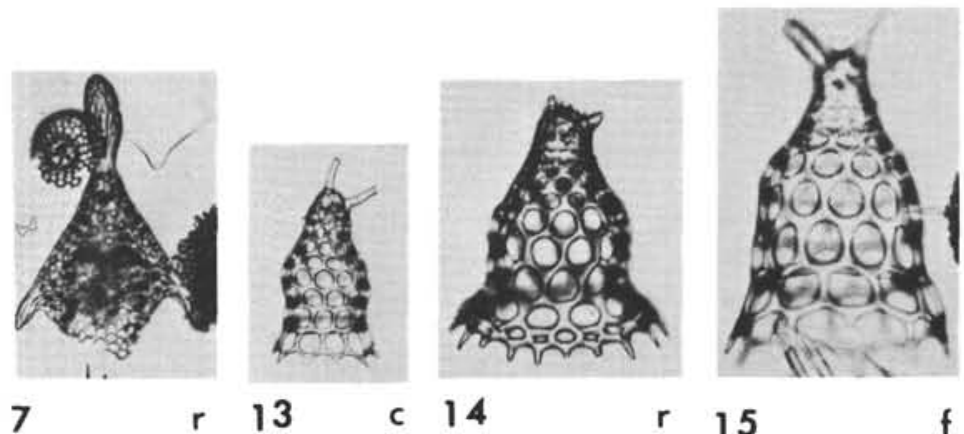

7

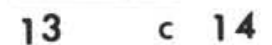

r 15 


\section{PLATE 3}

(Magnification: Figures 20-24, $\times 72$; Figures 10-12 $\times 100$;

Figures 1-9, 13-19, X108)

Figures 1,2 Thyrsocyrtis rhizodon Ehrenberg

1. USNM 178896, C12/1.

2. USNM 178854, F44/0.

Figures 3-8 Thyrsocyrtis hirsuta hirsuta (Krasheninnikov)

3. USNM $178897, \mathrm{~J} 19 / 3$.

4. USNM 178898, M26/0.

5. USNM $178855, \mathrm{~K} 15 / 2$.

6. USNM 178856, L18/4.

7. USNM $178821, \mathrm{~F} 42 / 0$.

8. USNM $178822, \mathrm{~T} 31 / 2$.

Figure 9 Thyrsocyrtis tarsipes Foreman n. sp. USNM 178774, 039/0.

Figure $10 \quad$ Orbula discipulus Foreman n. sp. USNM 178728, N40/0.

Figure $11 \quad$ Orbula comitata Foreman n. sp. USNM 178729, M41/4.

Figure 12 Orbula ducalis Foreman n. sp. USNM 178730, M40/0.

Figures 13-16 Thyrsocyrtis hirsuta tensa Foreman n. subsp. 13. 94-26-5(43-45), USNM 178857, U28/2.

14. 94-26-5(43-45), USNM $178858, \mathrm{~T} 32 / 4$.

15. USNM 178899, A55/3.

16. USNM 178859, E15/4.

Figure 17 Thyrsocyrtis hirsuta robusta Riedel and Sanfilippo USNM 178900, C29/3.

Figures 18, 19 Thyrsocyrtis (?) sp. aff. Gen. et sp. indet. Riedel and Sanfilippo, 1970, p. 526, pl. 8, fig. 4.

18. USNM $178901, \mathrm{M} 4 / 0$.

19. 94-26-5(43-45), USNM 178860, H18/0.

Figures 20,21 Bekoma bidarfensis Riedel and Sanfilippo

20. USNM 178775, P28/0.

21. USNM 178776, F24/3.

Figure 22 Bekoma (?) demissa Foreman n. sp. USNM 178731, D33/0.

Figure 23 Bekoma divaricata Foreman n. sp. 86-8-4(119-121), USNM 178732, F20/1.

Figure $24 \quad$ Bekoma campechensis Foreman n. sp. USNM 178733, Y23/0. 


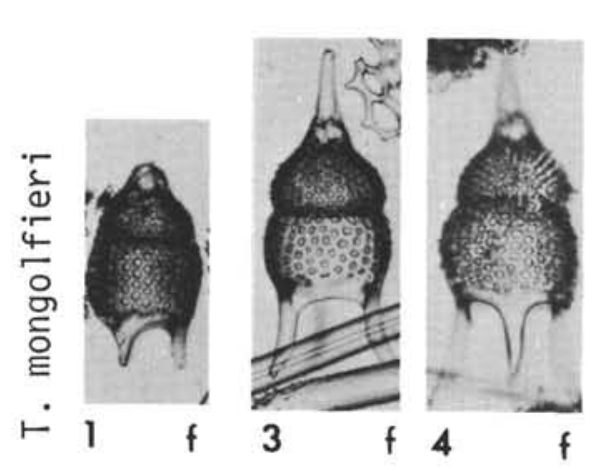

PLATE 3
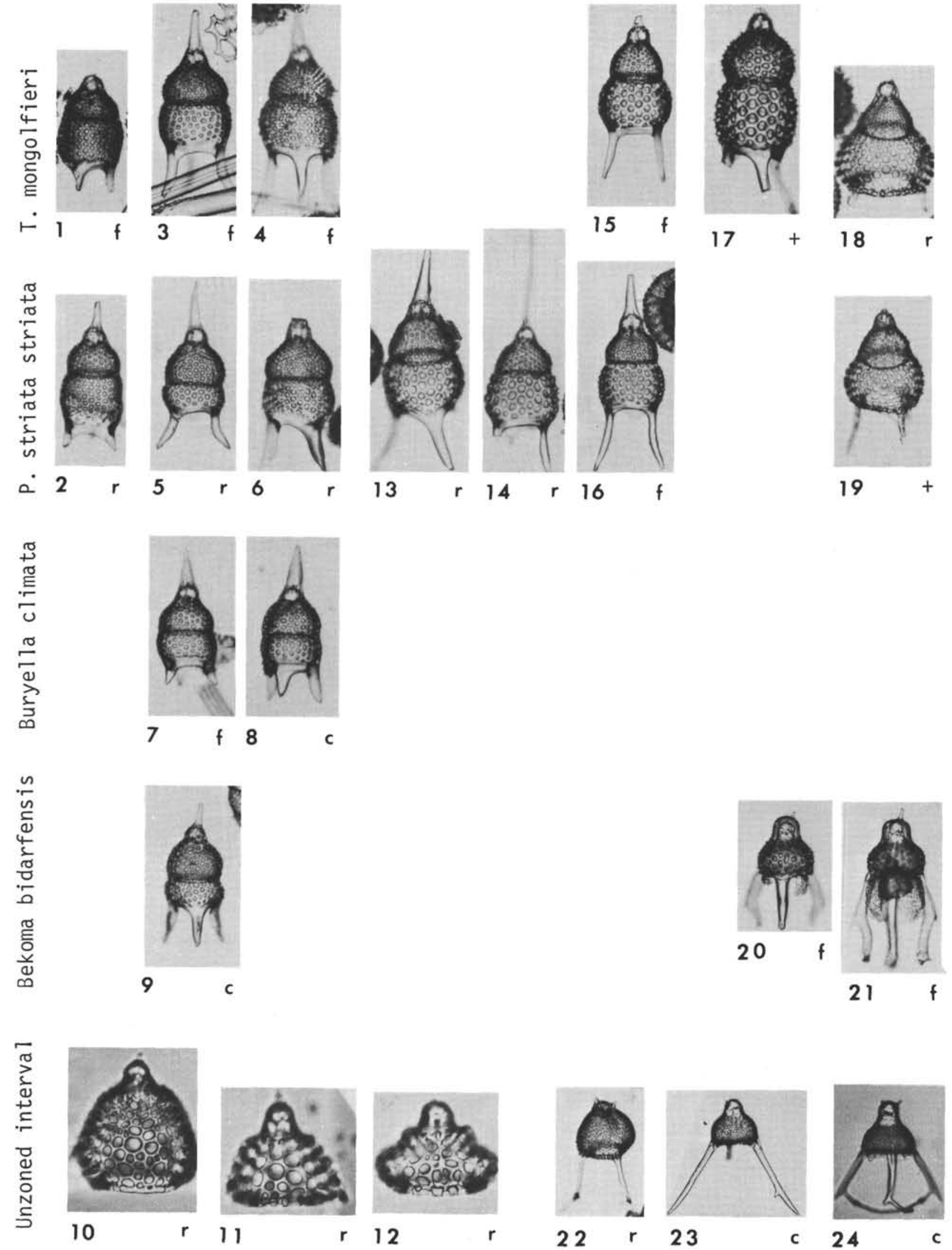
(Magnification $\times 108)$

Figures 1-5 Theocotyle (Theocotyle) cryptocephala (?) nigriniae Riedel and Sanfilippo

1. USNM 178902, F46/4.

2. USNM 178903, O31/0.

3. USNM 178861, S26/4.

4. USNM 178823, L33/4.

5. USNM $178824, \mathrm{Z} 45 / 0$.

Figures 6,7 Theocotyle (Theocotyle) cryptocephala cryptocephala (Ehrenberg) (?)

6. USNM 178904, U21/2.

7. USNM 178905, G19/3.

Figures 8-10 Theocotyle (Theocotylissa) auctor Foreman n. sp.

8. USNM 178777, C 15/2.

9. 94-31(CC), USNM 178778, L26/0.

10. 94-31(CC), USNM 178779, E12/2.

Figure $11 \quad$ Theocotyle (Theocotyle) cryptocephala (?) conica Foreman n. subsp.

USNM 178906, F42/4.

Figure 12 Theocotyle (Theocotyle) venezuelensis Riedel and Sanfilippo

USNM 178907, L20/0.

Figures 13-15 Theocotyle (Theocotylissa) alpha Foreman n. sp.

13. USNM 178825, P43/1.

14. USNM $178826, \mathrm{H} 43 / 1$.

15. 94-31(CC), USNM 178780, B28/0.

Figures 16-20 Theocotyle (Theocotylissa) ficus (Ehrenberg)

16. USNM 178908, E10/3.

17. USNM 178909, R34/0.

18. USNM 178862, T31/0.

19. USNM $178863, \mathrm{U} 25 / 0$.

20. USNM $178827, \mathrm{R} 46 / 3$. 
PLATE 4
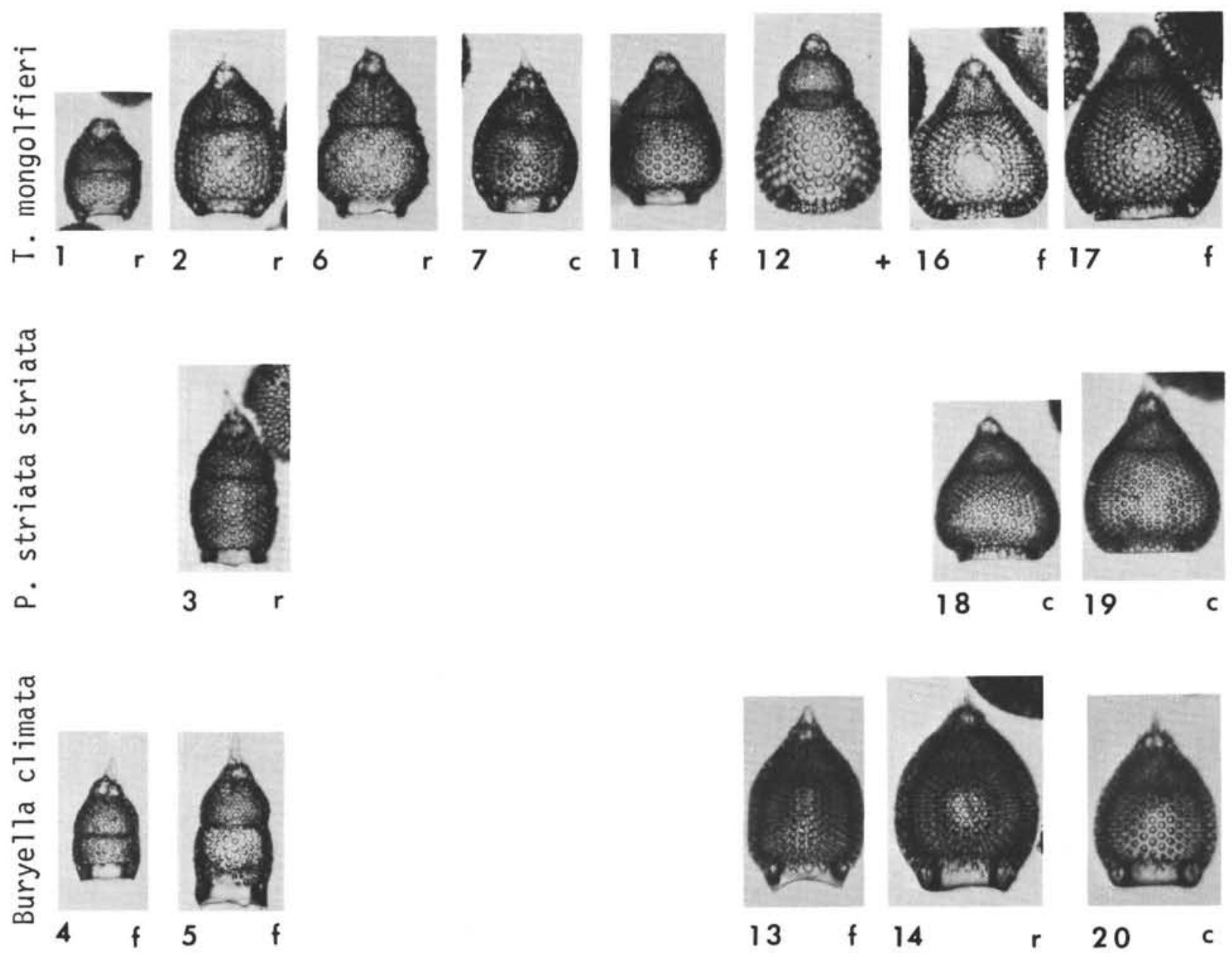

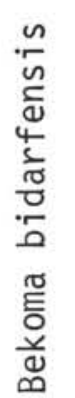
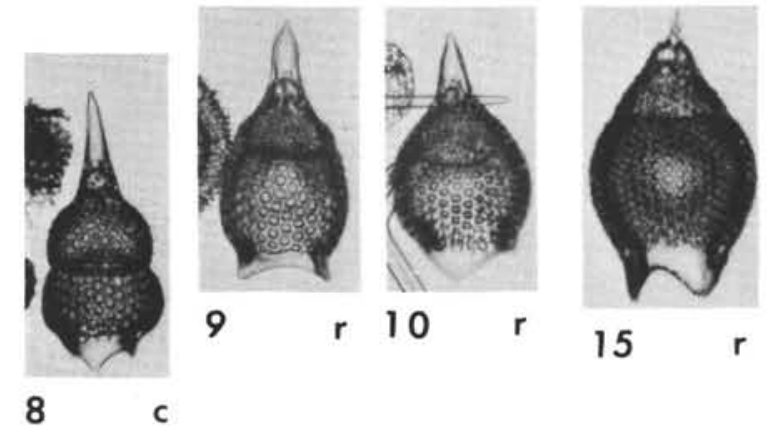

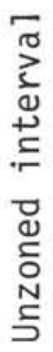




\section{PLATE 5}

(Magnification: Figure $8 \times 100$, all others $\times 108$ )

Figures 1-2 Theocotyle (Theocotylissa) (?) fimbria Foreman $\mathrm{n}$. sp.

1. USNM 178828, Q28/4.

2. 94-31(CC), USNM $178781, \mathrm{H} 28 / 2$.

Figures 3-5 Pterocodon (?) ampla Brandt (?)

3. USNM $178782, \mathrm{~K} 15 / 4$.

4. USNM 178783, P19/3.

5. USNM $178784, \mathrm{P} 44 / 3$.

Figure 6

Pterocodon (?) sp.

94-31(CC), USNM 178785, F27/1.

Figure $7 \quad$ Pterocodon (?) tenellus Foreman n. sp.

USNM 178786, K42/1.

Figure $8 \quad$ Theocorys phyzella Foreman n. sp. USNM 178787, W14/1.

Figures 9, 10 Theocorys anapographa Riedel and Sanfilippo

9. 94-22-3(42-44), USNM 178910, K38/2.

10. USNM $178864, \mathrm{G} 34 / 3$.

Figures 11-13 Theocorys acroria Foreman n. sp.

11. 94-30(CC), USNM 178829, W30/2.

12. USNM $178788, \mathrm{C} 43 / 0$.

13. USNM $178789, \mathrm{~N} 18 / 1$.

Figures 14-15 Theocorys anaclasta Riedel and Sanfilippo

14. USNM 178911, O17/2.

15. 94-26-5(43-45), USNM 178865, T17/0. 


\section{Plate 5}

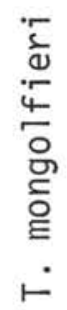

तु
$\frac{0}{2}$
$\frac{1}{4}$

它

$\therefore$
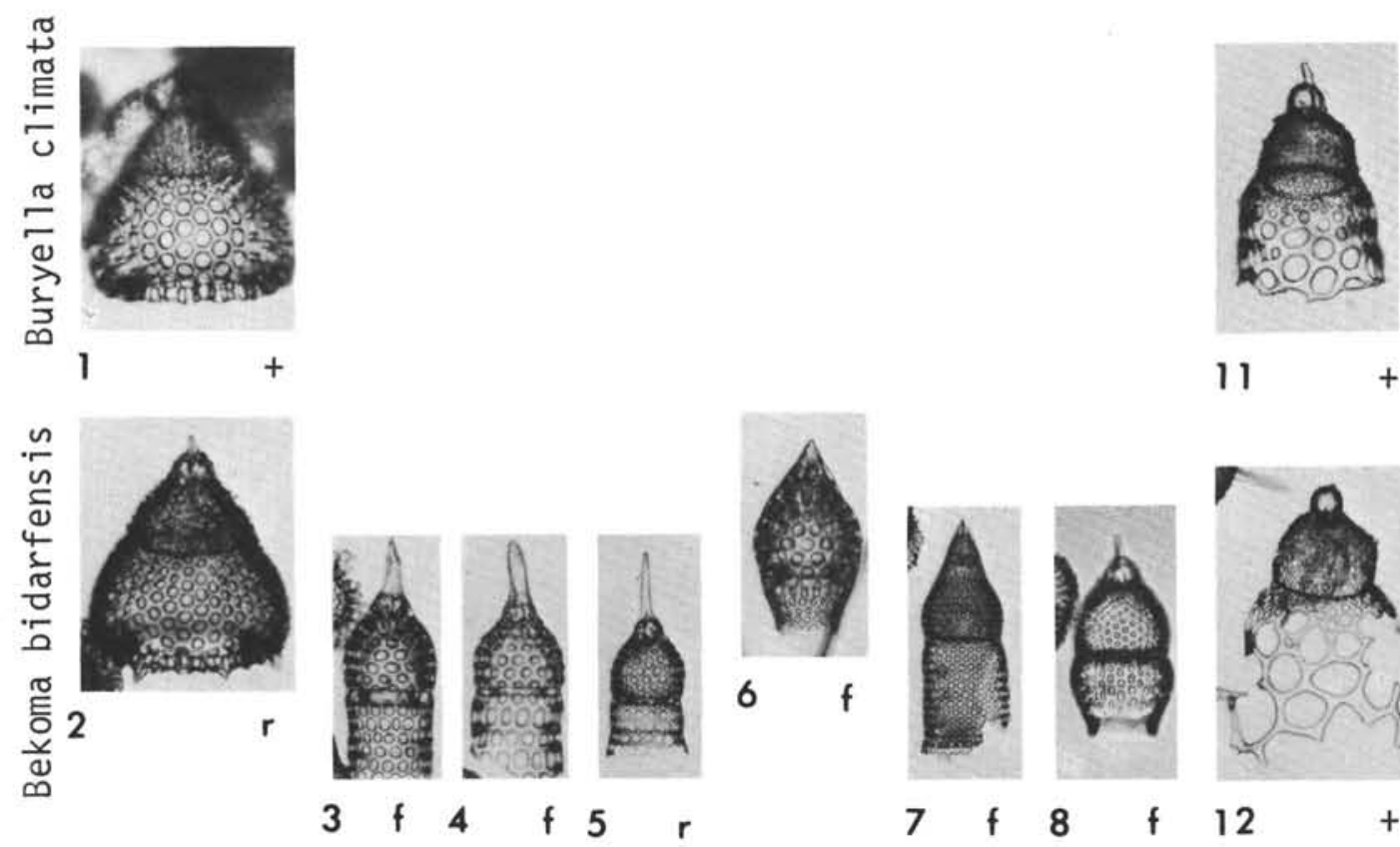

11
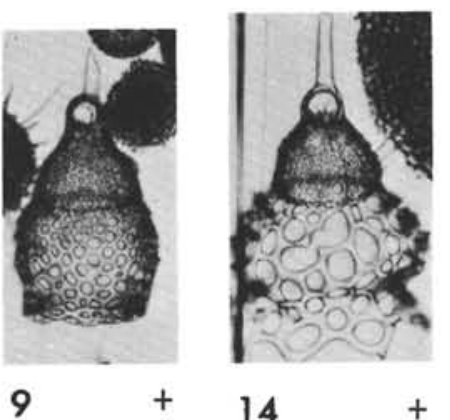

14

$+$

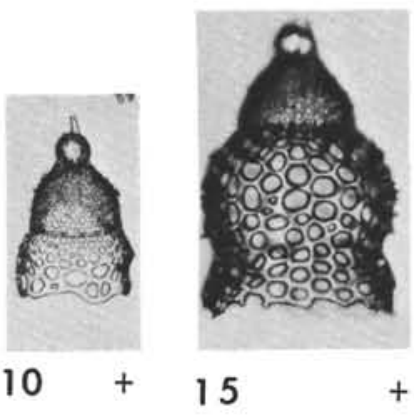

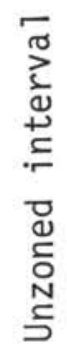


PLATE 6

(Magnification $\times 108$ )

Figure $1 \quad$ Lamptonium (?) incohatum Foreman n. sp. USNM 178734, S34/2.

Figure 2 Lamptonium (?) colymbus Foreman n. sp. USNM 178735, F37/0.

Figures 3-5 Lamptonium pennatum Foreman n. sp.

3. USNM 178830, A14/4.

4. USNM 178790, H17/3.

5. USNM 178736, U40/3.

Figures 6-9 Lamptonium fabaeforme fabaeforme (Krasheninnikov) (?)
6. USNM 178912, A16/3.
7. USNM 178866, P10/0.
8. USNM 178831, M15/2.
9. USNM 178791, K19/3.

Figures 10-12 Lamptonium fabaeforme (?) chaunothorax Riedel and Sanfilippo

10. 94-21-3(118-120), USNM 178913, X16/2.

11. USNM 178867, R26/0.

12. USNM $178832, \mathrm{Z} 27 / 2$.

Figures 13, 14 Lamptonium fabaeforme (?) constrictum Riedel and Sanfilippo

13. USNM 178914, B31/3.

14. USNM 178868, Q23/1.

Figures 15, 16 Lamptonium sanfilippoae Foreman n. sp.

15. USNM 178869, K35/0.

16. USNM 178833, D43/0. 


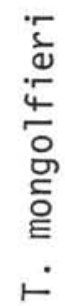

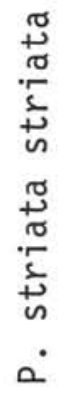

$\frac{n}{n}$
$\frac{1}{0}$
4
4
$\frac{7}{0}$
$\frac{0}{0}$
0
$\frac{0}{0}$
0
0
0

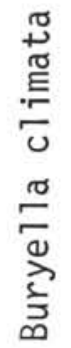

PLATE 6
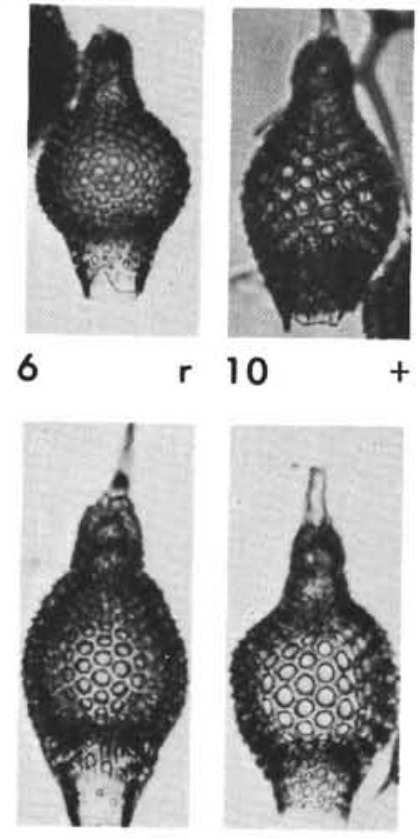

7
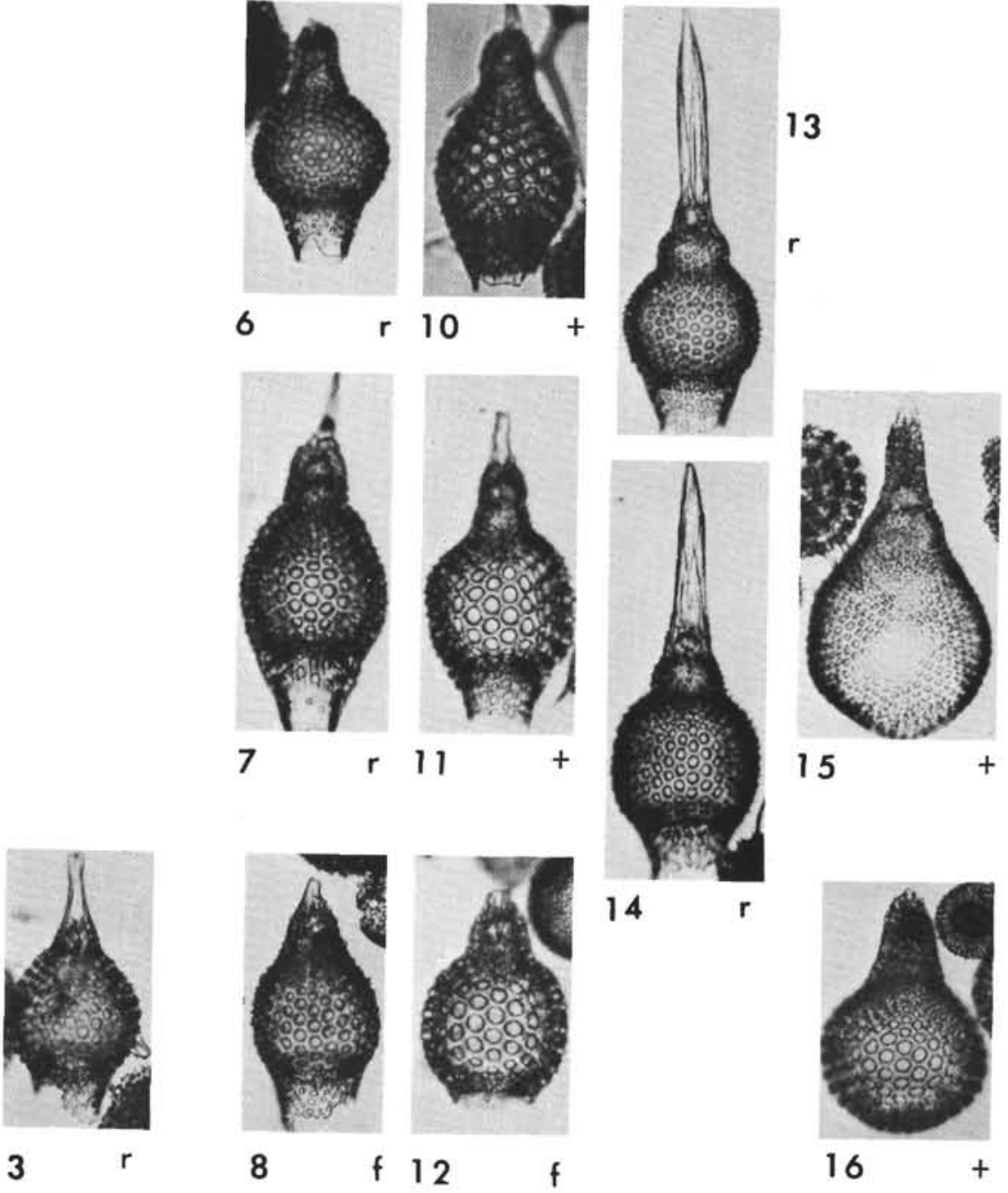

8

f 12
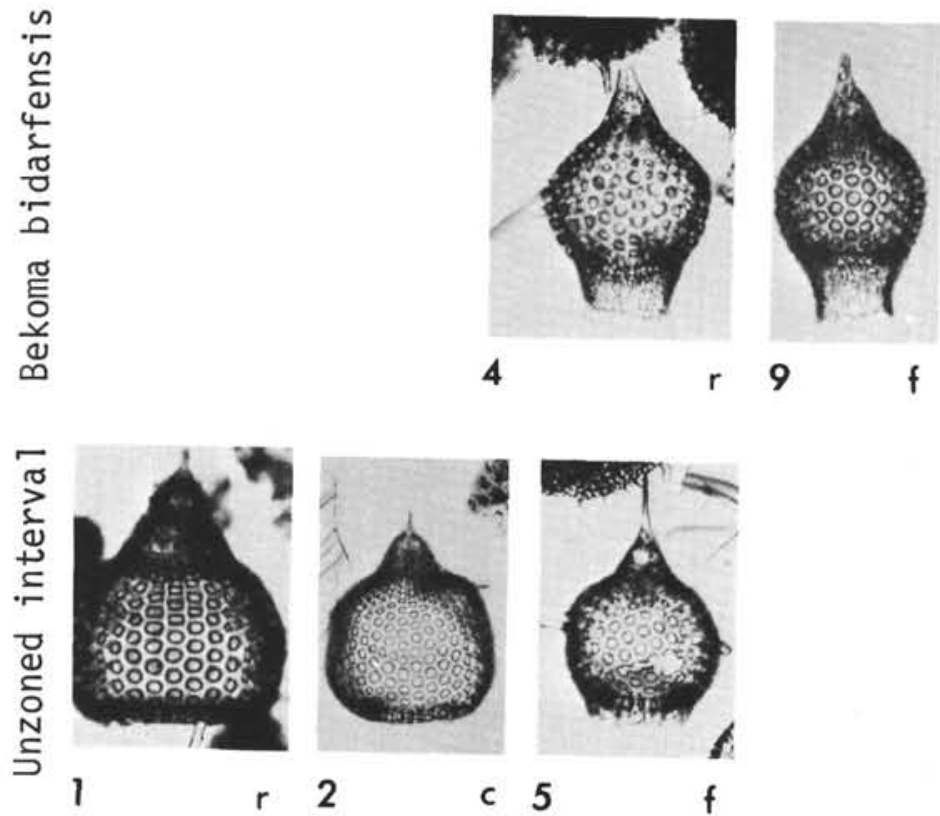
PLATE 7

(Magnification: Figures 9-14 X100; Figures 15-17, X108;

Figures 1-8, X116)

Figures 1-4, 7, 8 Phormocyrtis striata exquisita (Kozlova)

1. USNM 178870, L33/0.

2. USNM 178834, G29/2.

3. USNM 178792, N20/3.

4. USNM 178737, K28/0.

7. USNM $178835, \mathrm{H} 24 / 2$.

8. USNM 178793, U20/2.

Figures 5, 6, 9 Phormocyrtis striata striata Brandt

5. USNM 178915, F20/4.

6. USNM $178871, \mathrm{~N} 15 / 3$.

9. USNM 178916, D29/0.

Figure $10 \quad$ Phormocyrtis turgida (Krasheninnikov) USNM 178794, R42/4.

Figures 11, 12, Phormocyrtis cubensis (Riedel and Sanfilippo) 14

11. USNM 178836, J41/3.

12. USNM $178795, \mathrm{~S} 12 / 3$.

14. USNM 178796, R48/0.

Figure $13 \quad$ Tricolocampe vitrea Krasheninnikov (?) 94-30-2(44-46), USNM 178837, J22/2.

Figure $15 \quad$ Gen. et sp. indet.

96-3-3(42-44), USNM 178797, U42/3.

Figures 16, 17 Amphipternis clava (Ehrenberg)

16. 94-28-5(43-45), USNM 178872, B24/1.

17. $94-30-1(80-82)$, USNM 178838, L37/4.

Figure 18 Amphipternis sp. cf. ? Stichomitra alamedaensis (Campbell and Clark)

86-8-4(46-48), USNM 178738, G37/3. 
PLATE 7
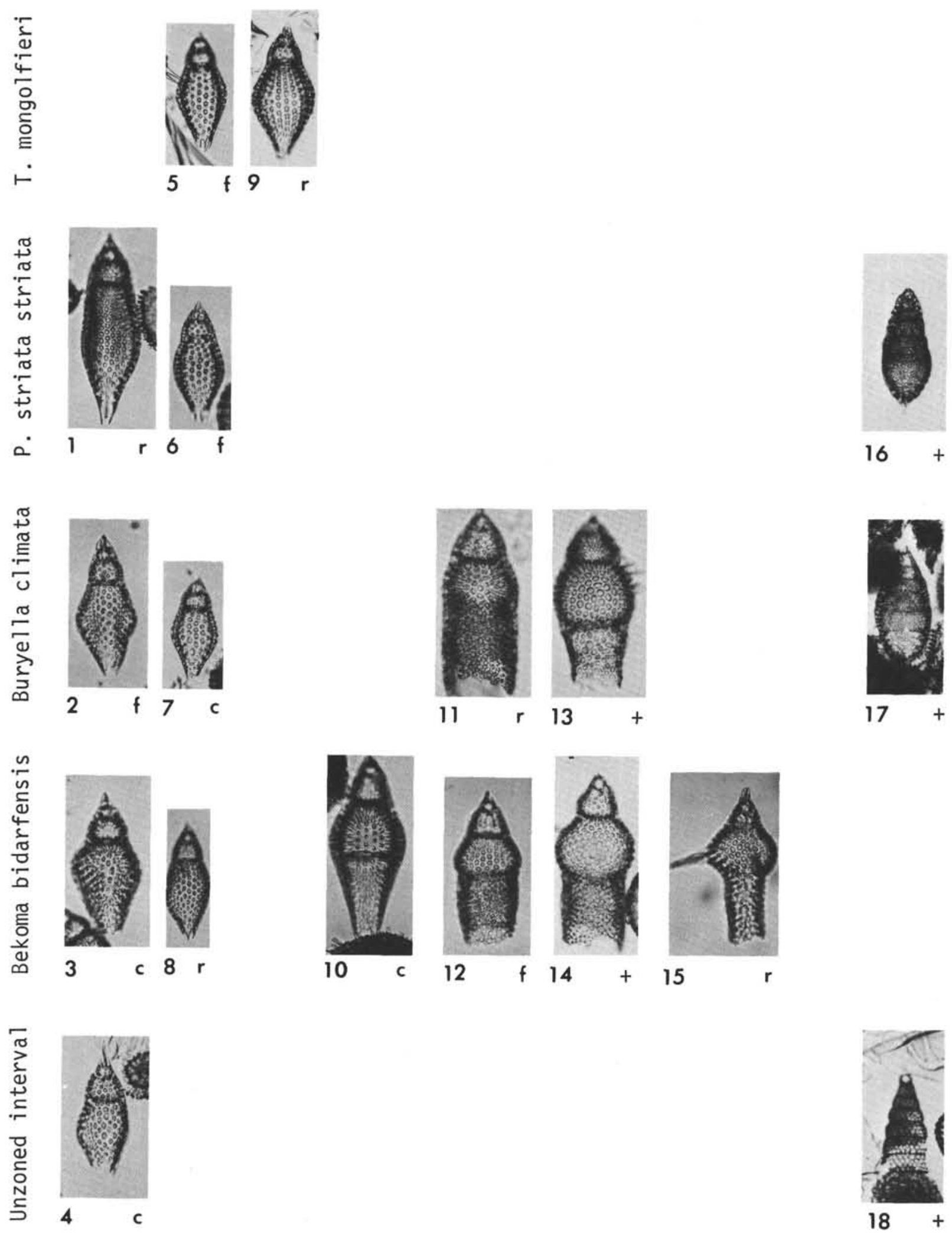
PLATE 8

(Magnification $\times 116$ )

Figures 1-3 Buryella clinata Foreman n. sp.

1. USNM 178917, P47/1.

2. USNM 178873, T11/0.

3. USNM 178839, C34/1.

Figures 4, $5 \quad$ Buryella tetradica Foreman n. sp.

4. USNM 178798, S16/3.

5. USNM $178739, \mathrm{~L} 32 / 3$.

Figure 6

Theocampe mongolfieri (Ehrenberg) USNM 178740, T30/0.

Figure $8 \quad$ Buryella pentadica Foreman F. n. sp. USNM 178740, T30/0.

Figures 7, 9.13 Theocampe amphora (Haeckel) group

7. USNM 178874, U32/0.

9. USNM 178919, N24/4.

10. USNM $178875, \mathrm{~J} 18 / 3$.

11. USNM 178920, L35/1.

12. USNM 178921, N16/0.

13. USNM 178876, V30/4.

Figures 14-17 Theocampe urceolus (Haeckel)

14. USNM 178922, S40/4.

15. USNM 178877, L12/3.

16. USNM 178878, E44/0.

17. USNM $178840, \mathrm{X} 48 / 0$.

Figure 18 cf. Lithomitra lineata (Ehrenberg) group 94-28-3(43-45), USNM 178879, U10/4.

Figure 19 Lithomitra lineata (Ehrenberg) group 96-3-4(42-44), USNM 178799, F43/4.

Figures 20-22 Lithomitra docilis Foreman n. sp.

20. USNM 178923, D45/2.

21. 96-3-4(42-44), USNM 178800, S22/0.

22. USNM 178741, S20/2.

Figures 23-26 Lophocyrtis biaurita (Ehrenberg)

23. USNM 178924, B26/2.

24. USNM $178925, \mathrm{X} 37 / 2$.

25. USNM $178880, \mathrm{~L} 22 / 2$.

26. USNM 178841, A42/0. 
PLATE 8
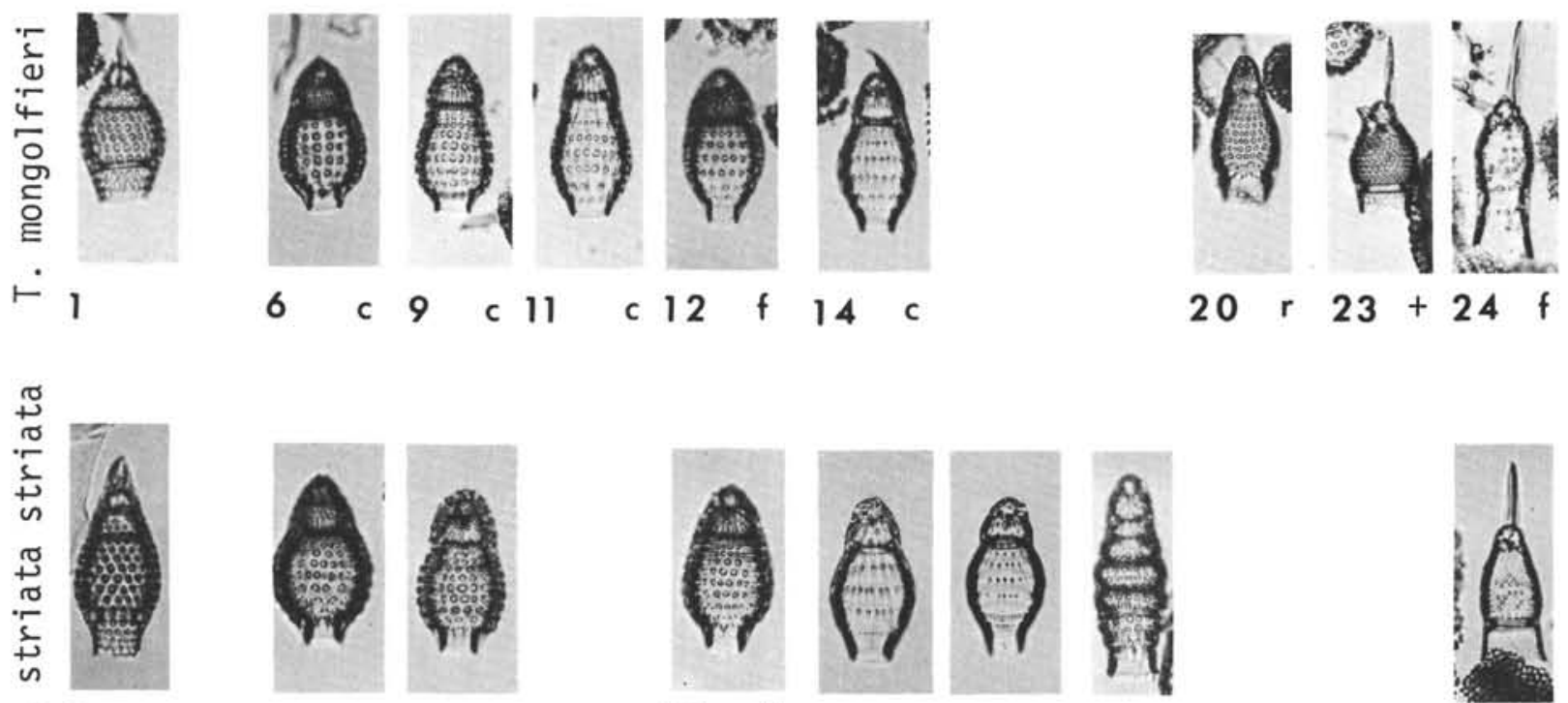

$\therefore 2 r$
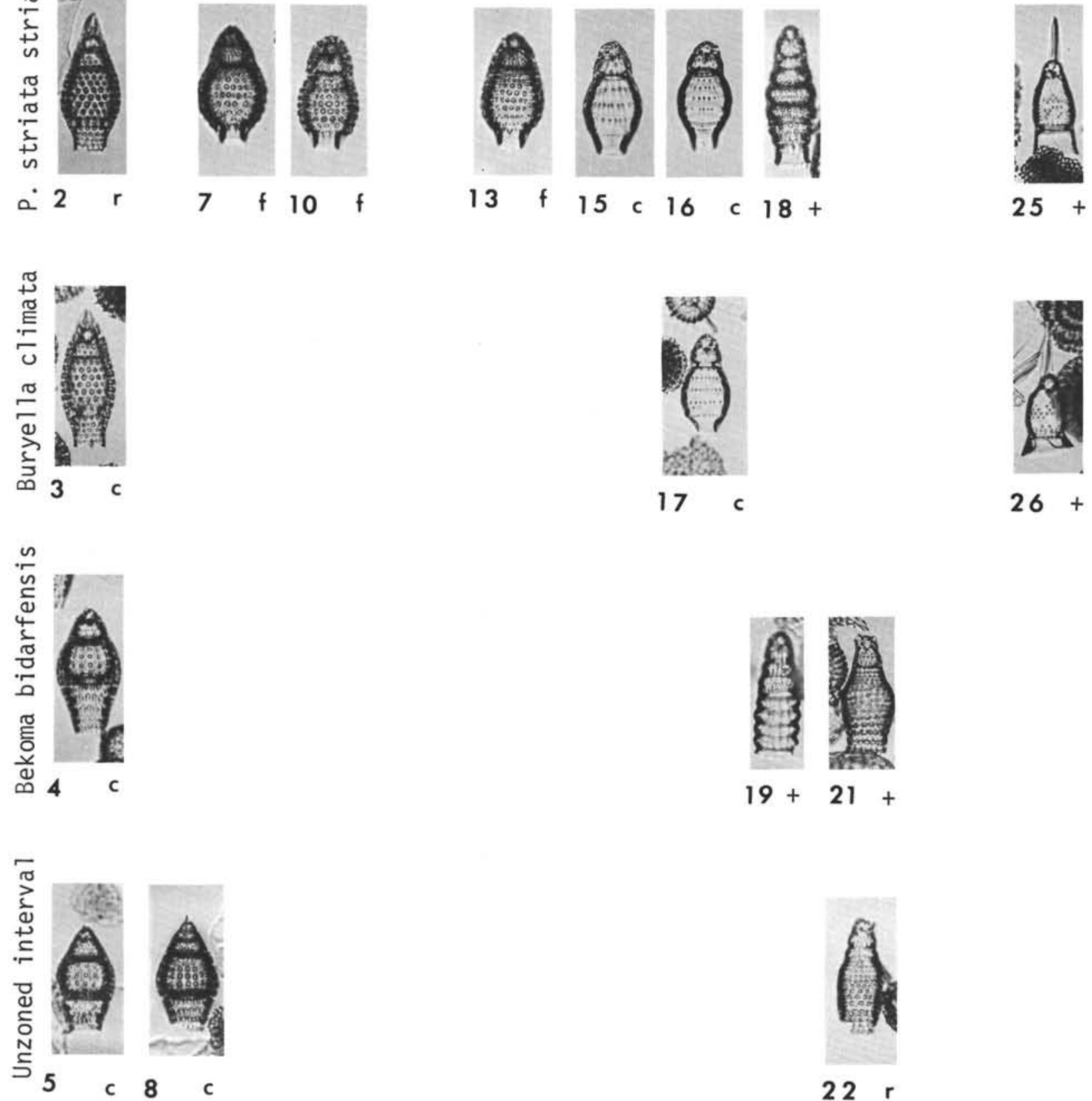
PLATE 9

(Magnification $\times 144)$

Figure 1 Amphipternis sp. cf. ? Stichomitra alamedaensis (Campbell and Clark)

86-8-3(44-46), USNM 178742, O26/3.

Figure 2 Amphipternis clava (Ehrenberg) 94-27(CC), USNM 178881, S20/4.

Figures 3-5 Lithomitra docilis Foreman n. sp.

3. Holotype, 86-8(CC), USNM 178743, F15/0.

4. 94-27(CC), USNM 178882, L18/1.

5. 94-12-4(42-44), USNM 178955, S30/1.

Figures 6,7 Theocampe urceolus (Haeckel)

6. 94-28-5(43-45), USNM 178883, F41/2.

7. 94-16-2(42-44), USNM 178956, T39/2.

Figures 8,9 Theocampe amphora (Haeckel) group

8. 94-17-1(36-38), USNM 178957, V42/2.

9. 94-17-1(36-38), USNM 178958, F36/0.

Figure 10 Theocampe sp. aff. T. amphora (Haeckel) group 94-17-1(36-38), USNM 178959, P8/2.

Figures 11, 12 Theocampe pirum (Ehrenberg)

11. 94-16-2(42-44), USNM 178960, L43/0.

12. $94-12-4(42-44)$, USNM 178961, B14/0.

Figures 13, 14 Buryella tetradica Foreman n. sp.

13. 86-8(CC), USNM 178744. T25/0.

14. Holotype, 96-3-5(42-44), USNM 178801, G18/3.

Figures 15, 16 Buryella pentadica Foreman n. sp.

15. 86-8(CC), USNM 178745, T21/3.

16. Holotype, 86-8-4(119-121), USNM 178746 , Q42/0.

Figure 17 Theocampe mongolfieri (Ehrenberg) 94-16-2(42-44), USNM 178962, T24/0.

Figure 18 Calocyclas hispida (Ehrenberg)

94-17-2(42-44), USNM 178963, A16/0.

Figure 19 Buryella clinata Foreman n. sp.

Holotype, 94-29(CC), USNM 178884, J43/0.

Figure 20 Calocycloma ampulla (Ehrenberg)

94-20-2(39-41), USNM 178926, W16/0.

Figure 21 Dictyoceras caia Foreman n. sp.

Holotype, 86-8-4(119-124), USNM 178747, T27/1. 
PLATE 9
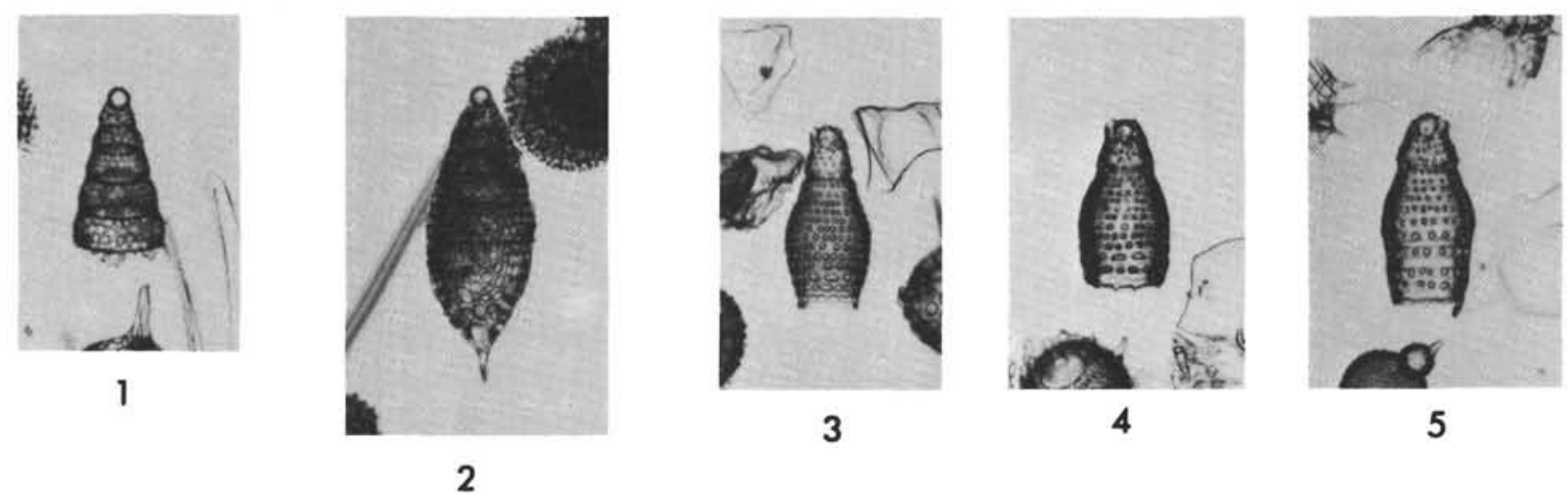

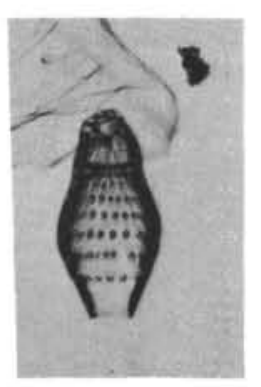

6

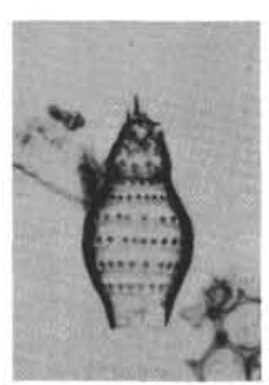

7

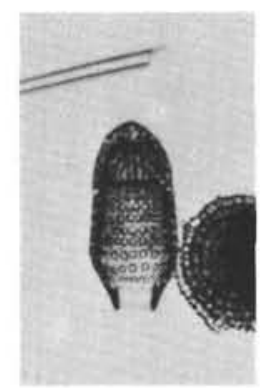

8
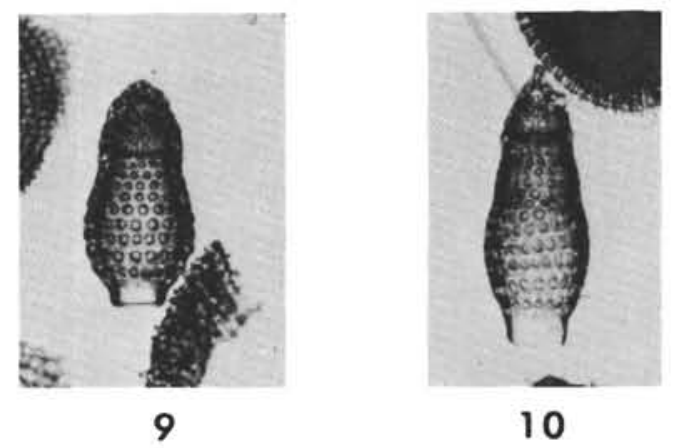

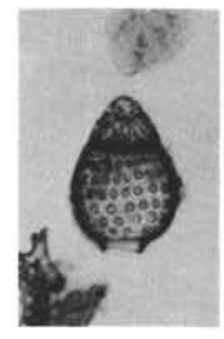

11

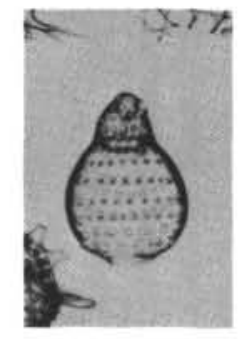

12

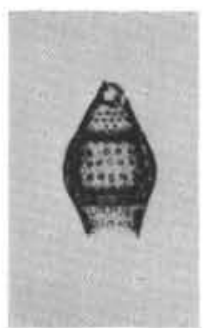

13

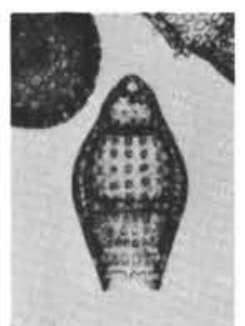

14

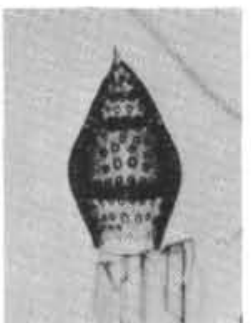

15

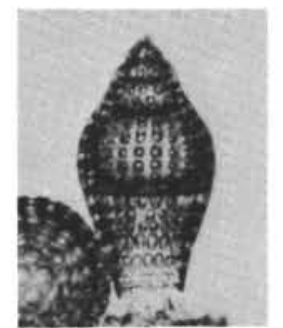

16

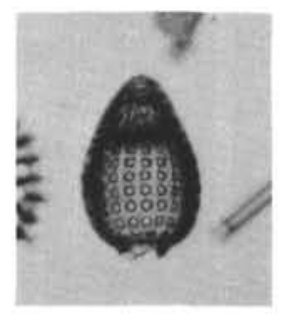

17

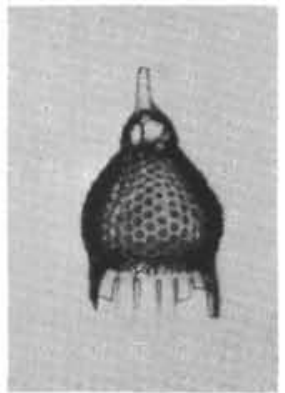

18

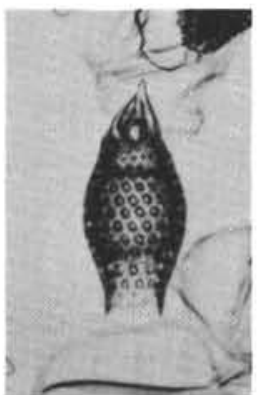

19

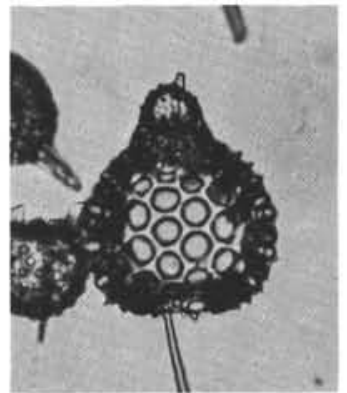

20

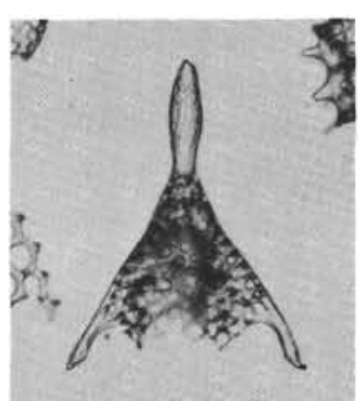

21 
PLATE 10

(Magnification X144)

Figures 1,2 Bekoma campechensis Foremen n. sp.

1. 86-8-4(119-121), USNM 178748, J21/0.

2. Holotype, 86-8-4(119-121), USNM 178749, $\mathrm{H} 44 / 4$.

Figures 3, $4 \quad$ Bekoma divaricata Foreman n. sp.

3. Holotype, 86-8-4(119-121), USNM 178750,

$\mathrm{P} 45 / 3$.

4. 86-8-4(119-121), USNM 178751, S42/1.

Figure $5 \quad$ Bekoma (?) demissa Foreman n. sp.

Holotype, 86-8-4(119-121), USNM 178752, J44/3.

Figure 6 Bekoma bidarfensis Riedel and Sanfilippo 96-3-5(42-44), USNM 178802, J18/3.

Figures 7,8 Orbula comitata Foreman n. sp.

7. Holotype, 86-8-3(46-48), USNM 178753, E42/0.

8. Top view, dorsal spine at left, $86-8(\mathrm{CC})$, USNM 178754, F47/0.

Figures 9, 10 Orbula discipulus Foreman n. sp.

9. Holotype, 86-8-4(119-121), USNM 178755, T19/1.

10. Top view, dorsal spine at left, $86-8(\mathrm{CC})$, USNM 178756, W44/2.

Figures 11, 12 Orbula ducalis Foreman n. sp.

11. Holotype, 86-8(CC), USNM 178757, S19/0.

12. Top view, dorsal spine at left, $86-8(\mathrm{CC})$, USNM 178758, M35/3. 
PLATE 10

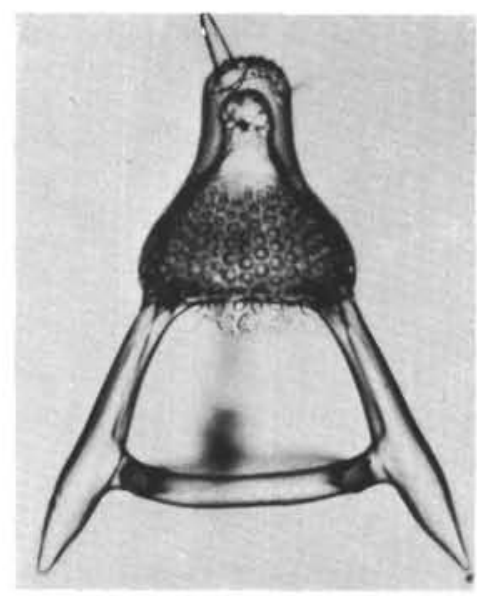

1
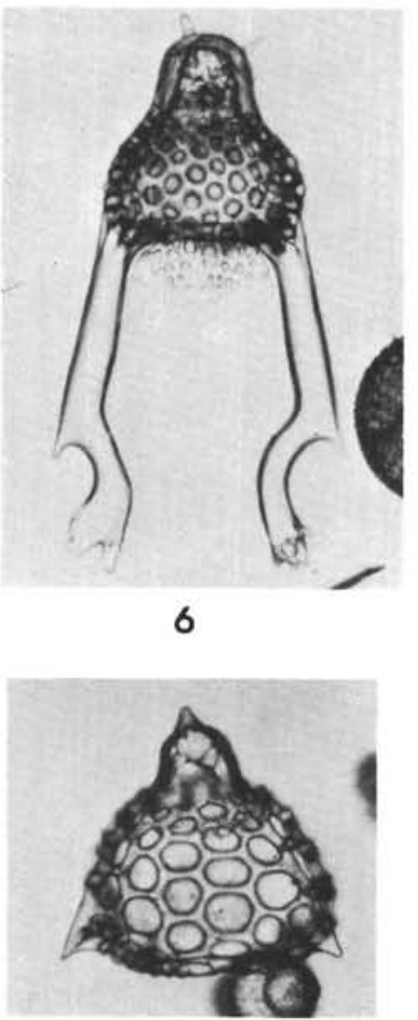

7

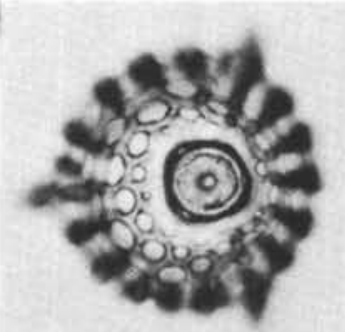

8

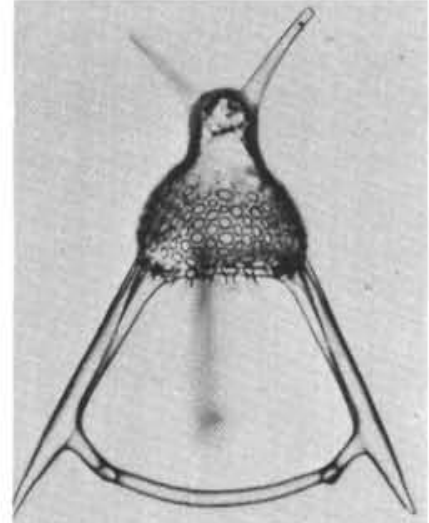

2

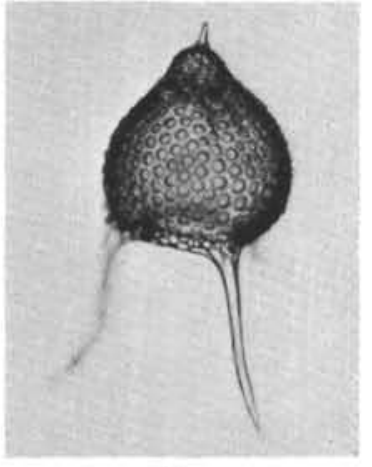

5

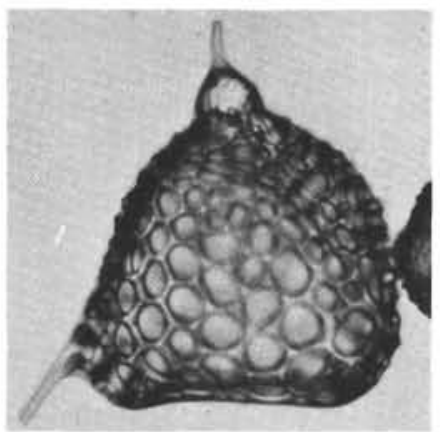

9

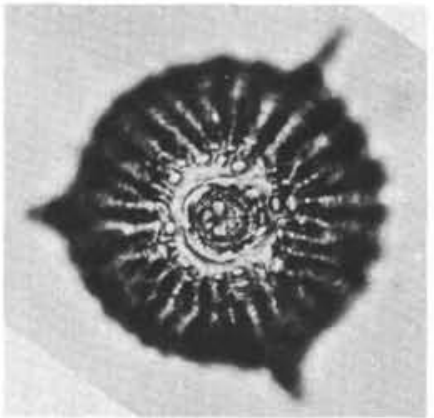

10
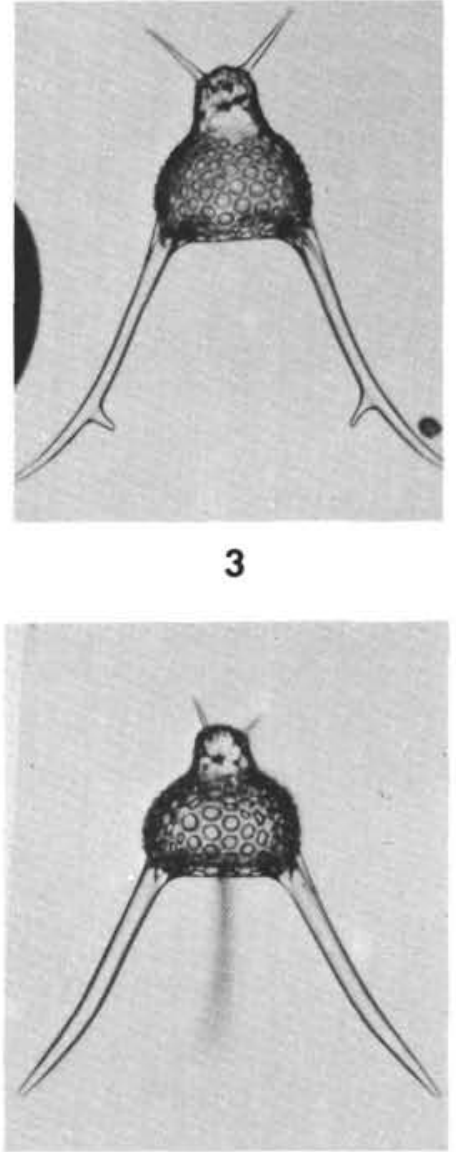

4
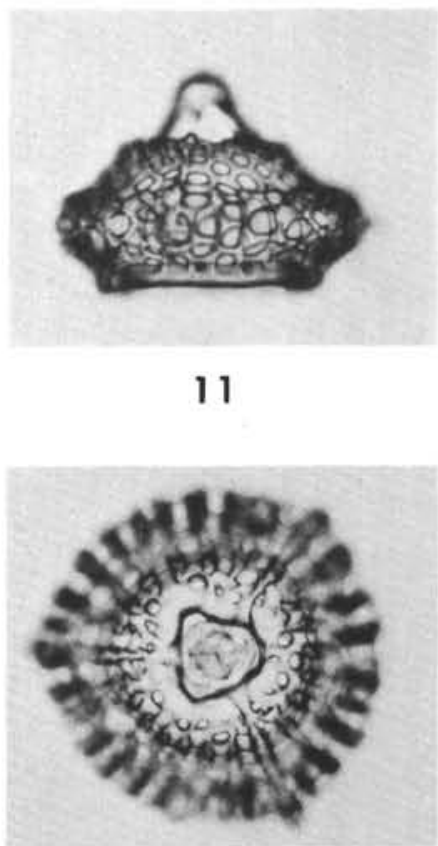

12 
PLATE 11

(Magnification X144)

Figures 1,2 Lychnocanoma auxilla Foreman n. sp.

1. 96-3-3(42-44), USNM 178803, J34/0.

2. Holotype, 96-3-3(42-44), USNM 178804, Q34/0.

Figure 3 Lithochytris vespertilio Ehrenberg 94-17-1(36-38), USNM 178964, K8/2.

Figures 4, $5 \quad$ Eusyringium lagena (Ehrenberg)

4. 94-20-2(39-41), USNM 178927, K28/0.

5. 94-20-2(39-41), USNM 178928, Y37/3.

Figure 6

Eusyringium fistuligerum (Ehrenberg)

94-17-2(42-44), USNM 178965, Q9/0.

Figure $7 \quad$ Lychnocanoma anacolum Foreman n. sp.

Holotype, 86-8-4(119-121), USNM 178759, R42/3.

Figure 8 Lychnocanoma sp. aff. L. bellum (Clark and Campbell)

96-3-3(42-44), USNM 178805, R28/0.

Figure 9 Lychnocanoma bellum (Clark and Campbell) 94-22-1(42-44), USNM 178929, B42/0.

Figure 10 Lychnocanoma amphitrite Foreman n. sp. Holotype, 95-6-4(42-44), USNM 178966, N37/2.

Figure $11 \quad$ Clathrocycloma capitaneum Foreman n. sp. Holotype, 86-8(CC), USNM 178760, D18/3.

Figure 12 Clathrocycloma parcum Foreman n. sp. Holotype, 86-8-4(119-121), USNM 178761, M31/3.

Figure 13 Lamptonium pennatum Foreman n. sp. Holotype, 94-31(CC), USNM 178806, K41/2.

Figure 14 Theocorys sp. aff. Theocorys (?) spongoconum (Kling) 94-11-2(42-44), USNM 178967, R18/0.

Figures 15, 19 Lamptonium (?) colymbus Foreman n. sp.

15. Holotype, 86-8(CC), USNM 178762, F24/1.

19. 86-8(CC), USNM 178763, W36/1.

Figures 16, 17 Lamptonium sanfilippoae Foreman n. sp. 16. Holotype, 94-30-2(114-116), USNM 178842, $\mathrm{H} 39 / 3$.

17. $94-29(C C)$, USNM $178885, \mathrm{~S} 39 / 2$.

Figure $18 \quad$ Lamptonium (?) incohatum Foreman n. sp. Holotype, 86-8-3(46-48), USNM 178764, T17/0. 
PLATE 11

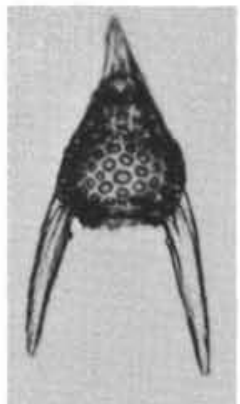

1

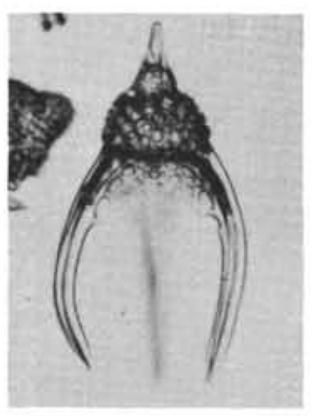

7

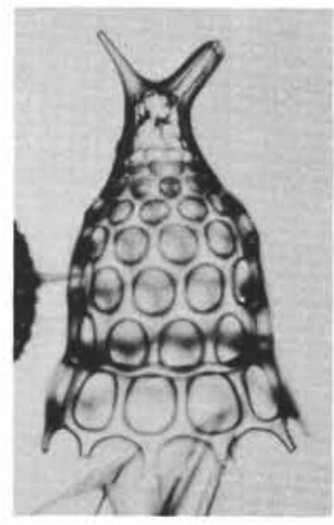

11

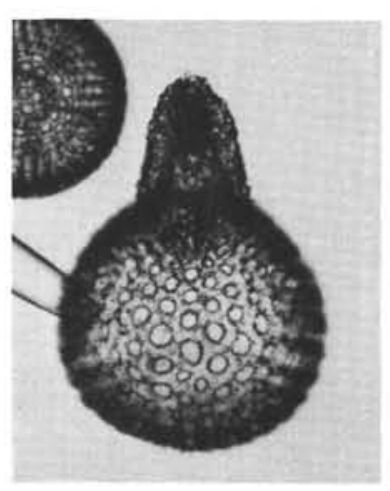

16

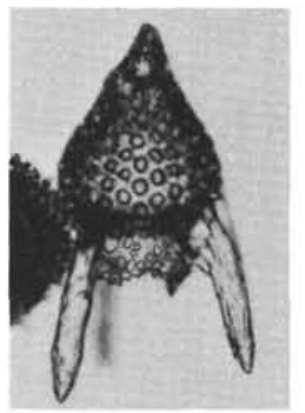

2

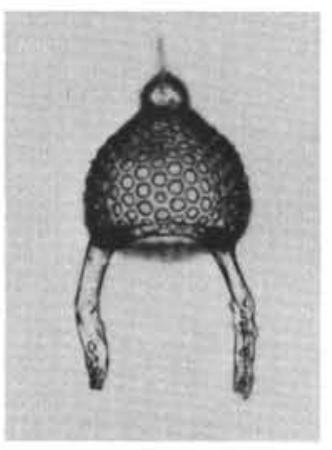

8

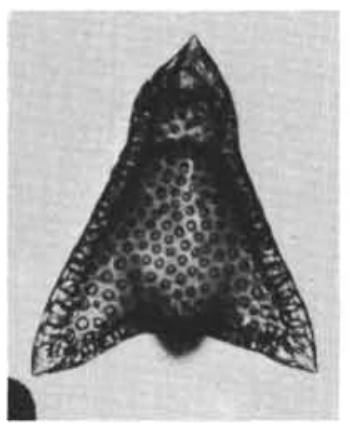

3

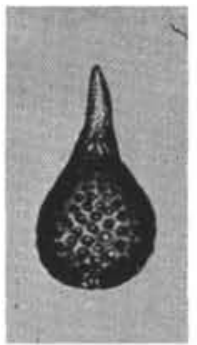

4

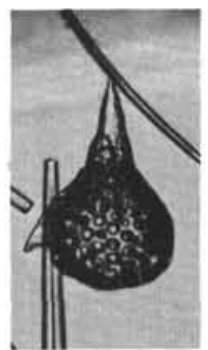

5

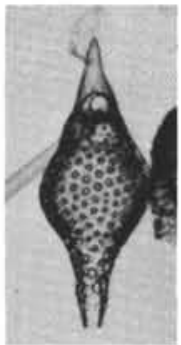

6

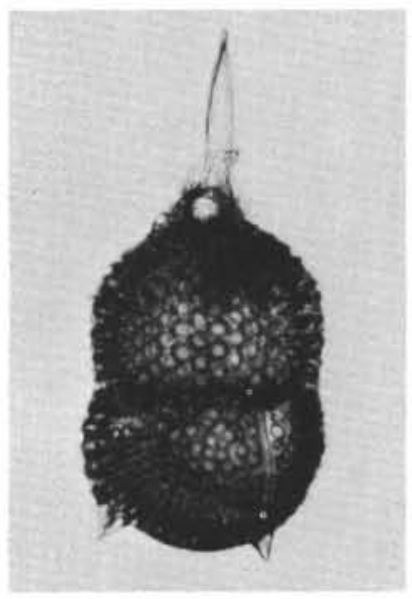

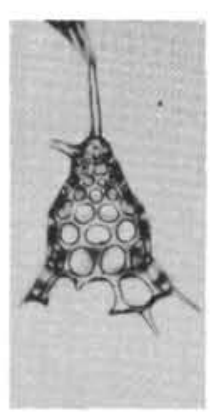

12

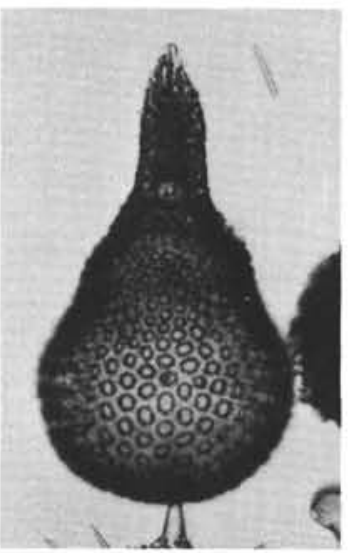

17

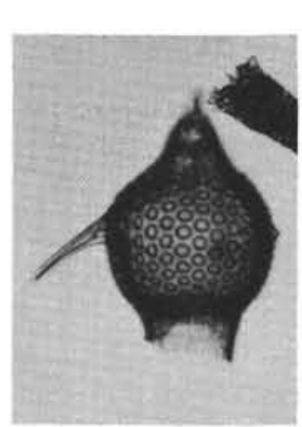

13

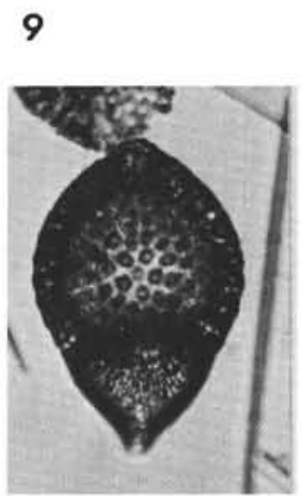

14

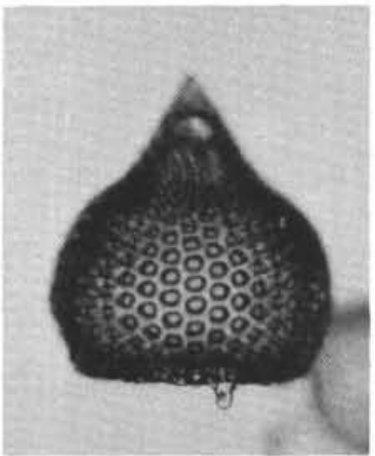

18

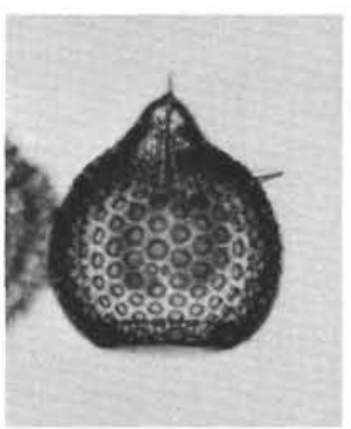

19 
PLATE 12

(Magnification: Figure $17 \times 150$, all others $\times 144$ )

Figure $1 \quad$ Theocorys (?) phyzella Foreman n. sp. Holotype, 96-3-5(42-44), USNM 178807, U28/0.

Figure 2 Theocorys acroria Foreman n. sp. Holotype, 96-3-5(42-44), USNM 178808, L40/3.

Figure 3 Rhopalocanium ornatum Ehrenberg 94-17-1(36-38), USNM 178968, G30/3.

Figure 4

Pterocodon (?) tenellus Foreman n. sp. Holotype, 94-31(CC), USNM 178809, R23/4.

Figure 5

Phormocyrtis striata exquisita (Kozlova) 86-8-3(46-48), USNM 178765, R30/2.

Figure 6

Phormocyrtis turgida (Krasheninnikov) 94-31(CC), USNM 178810, W29/2.

Figure 7

Thyrsocyrtis (?) sp. aff. Gen. et. sp. indet. Riedel and Sanfilippo, 1970, p. 526, pl. 8, fig. 4.

94-26-5(43-45), USNM 178886, C38/3.

Figure 8 Thyrsocyrtis hirsuta tensa Foreman n. subsp. Holotype, 94-27(CC), USNM 178887, C41/3.

Figures 9-11 Thyrsocyrtis triacantha (Ehrenberg)

9. 94-22-2(42-44), USNM 178930, K15/4.

10. 94-21-2(42-44), USNM 178931, N30/0.

11. $94-17-1(36-38)$, USNM 178843, J19/4.

Figure 12 Thyrsocyrtis (?) sp. = Gen. et sp. indet. Riedel and Sanfilippo, 1970, p. 526, pl. 8, fig. 4.

94-22-2(42-44), USNM 178932, P13/3.

Figure 13 Theocotyle (Theocotylissa) auctor Foreman n. sp. Holotype, 94-31(CC), USNM 178811, W20/2.

Figure $14 \quad$ Thyrsocyrtis tarsipes Foreman n. sp.

Holotype, 96-3-3(42-44), USNM 178812, H18/3.

Figure $15 \quad$ Thyrsocyrtis hirsuta hirsuta (Krasheninnikov) 94-27(CC), USNM 178888, O23/3.

Figure 16 Theocotyle (Theocotylissa) alpha Foreman n. sp. Holotype, 94-30-2(114-116), USNM 178844, X40/4.

Figure 17 Theocotyle (Theocotyle) cryptocephala (?) nigriniae Riedel and Sanfilippo (Ehrenberg) 94-29(CC), USNM 178889, G26/0.

Figure 18 Theocotyle (Theocotyle) cryptocephala cryptocephala Ehrenberg (?)

94-27(CC), USNM 178890, V39/3.

Figures 19,20 Theocotyle (Theocotyle) cryptocephala (?) conica Foreman n. subsp.

19. 94-22-4(42-44), USNM 178933, F37/3.

20. Holotype, 94-20-2(39-41), USNM 178934, $\mathrm{O} 24 / 0$. 
PLATE 12

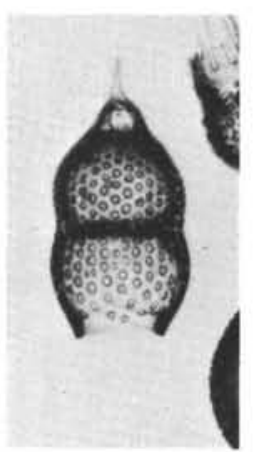

1

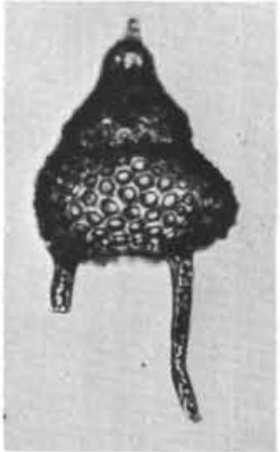

7

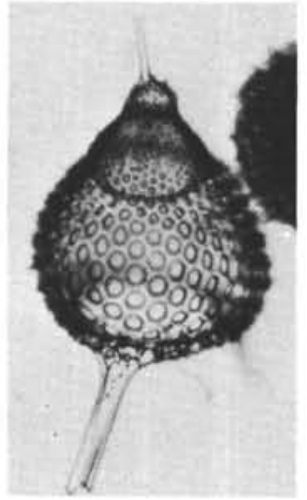

12

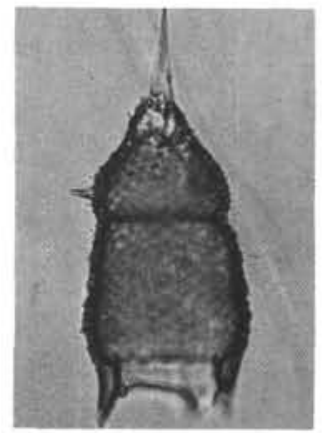

17

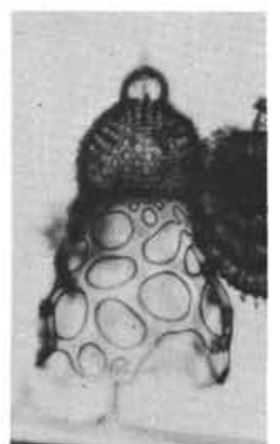

2

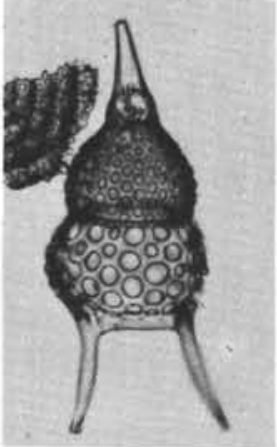

8

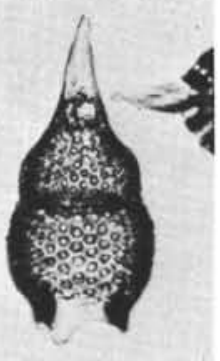

13

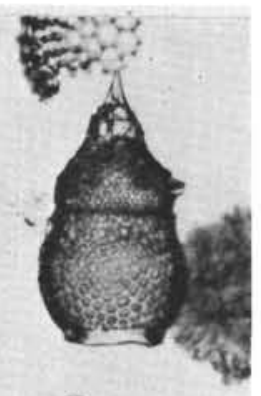

18

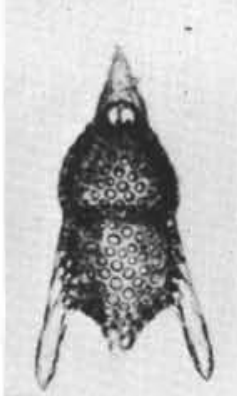

3

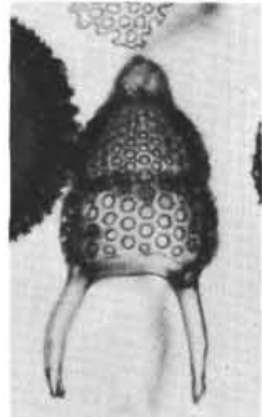

9

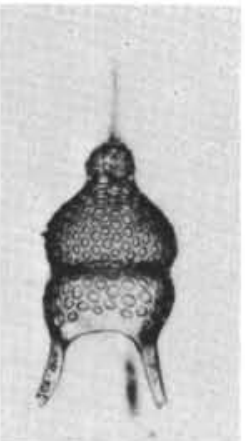

14

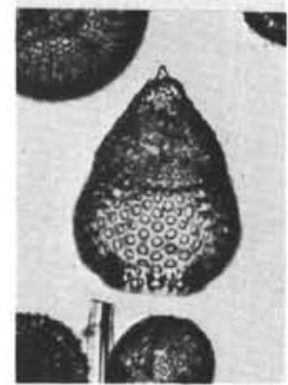

19

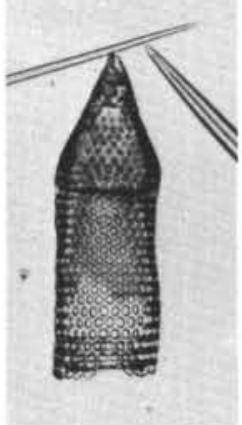

4
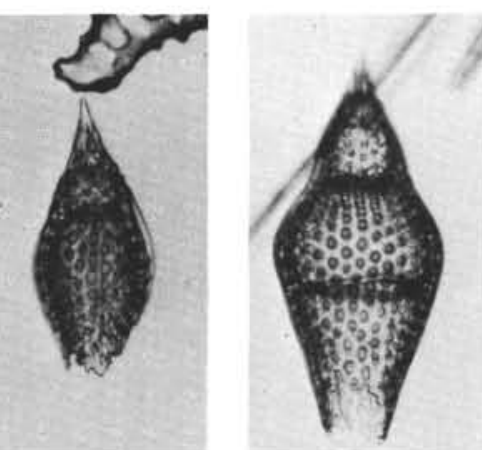

5

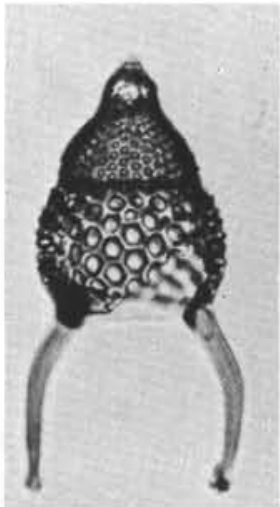

10

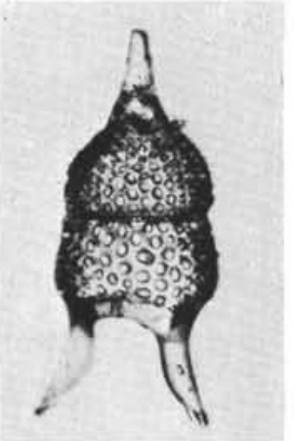

15

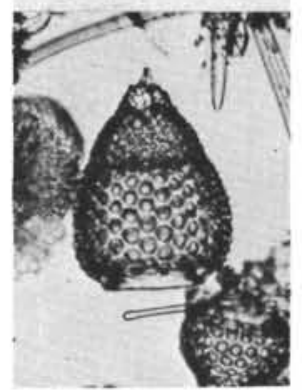

20
16

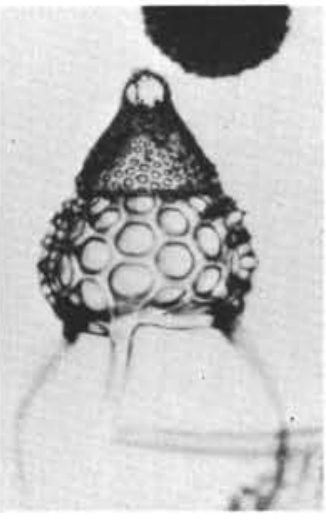

11
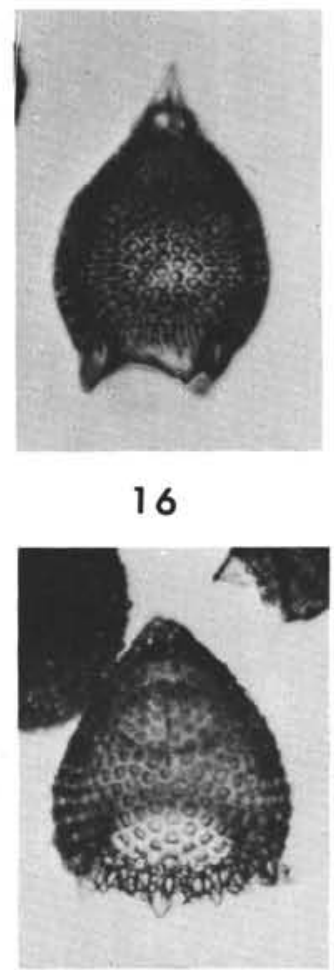

21 
PLATE 13

(Magnification: Figures 18, $20 \times 94$, all others $\times 144$ )

Figure 1 Theoperid, gen. and sp. indet. 95-13(CC), USNM 178935, P42/4.

Figure 2 Theocampe salillum Foreman 95-13(CC), USNM 178936, G44/2.

Figure 3 Theoperid, gen. and sp. indet. 95-13(CC), USNM 178937, K20/1.

Figure 4 Gongylothorax verbeeki (Tan Sin Hok) 95-13(CC), USNM 178938, J23/3.

Figure $5 \quad$ Amphipyndax stocki (Campbell and Clark) 95-13(CC), USNM 178939, S6/3.

Figure 6 Dictyomitra sp. 95-13(CC), USNM 178940, M20/3.

Figure 7 Dictyomitra torquata Foreman 95-13(CC), USNM 178931, S38/4.

Figure $8 \quad$ Pseudoaulophacus floresensis Pessagno 95-13(CC), USNM 178942, Q38/1.

Figure $9 \quad$ Alievium gallowayi (White) 95-13(CC), USNM 178943, P17/0.

Figure $10 \quad$ Crucella sp. 95-13(CC), USNM 178944, V34/3.

Figure $11 \quad$ Actinommid, gen. and sp. indet. 95-13(CC), USNM 178945, Q17/3.

Figure 12 Spongodiscid, cf. Spongodiscus (?) multus Kozlova 95-13(CC), USNM 178946, P37/2.

Figure 13 Actinommid, gen. and sp. indet. 95-13(CC), USNM 178947, G15/0.

Figure 14 Crucella sp. cf. C. espartoensis Pessagno 95-13(CC), USNM 178948, N38/3.

Figure 15 Spongodiscid, gen. and sp. indet. 95-13(CC), USNM 178949, L25/2.

Figures 16, 17 Dictyomitra ssp.

97-11(CC)

16. USNM 178950, K39/2.

17. USNM 178953, T22/0.

Figures 18, 19 Crucella ssp.

97-11(CC)

18. USNM 178952, B21/0.

19. USNM 178953, U31/0.

Figure 20 Actinommid, gen. and sp. indet. 97-11(CC), USNM 178954, O44/2. 
PLATE 13

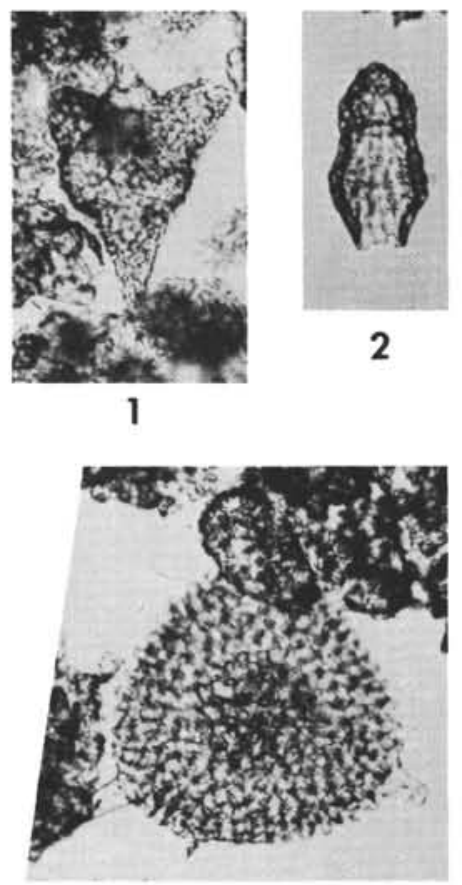

8
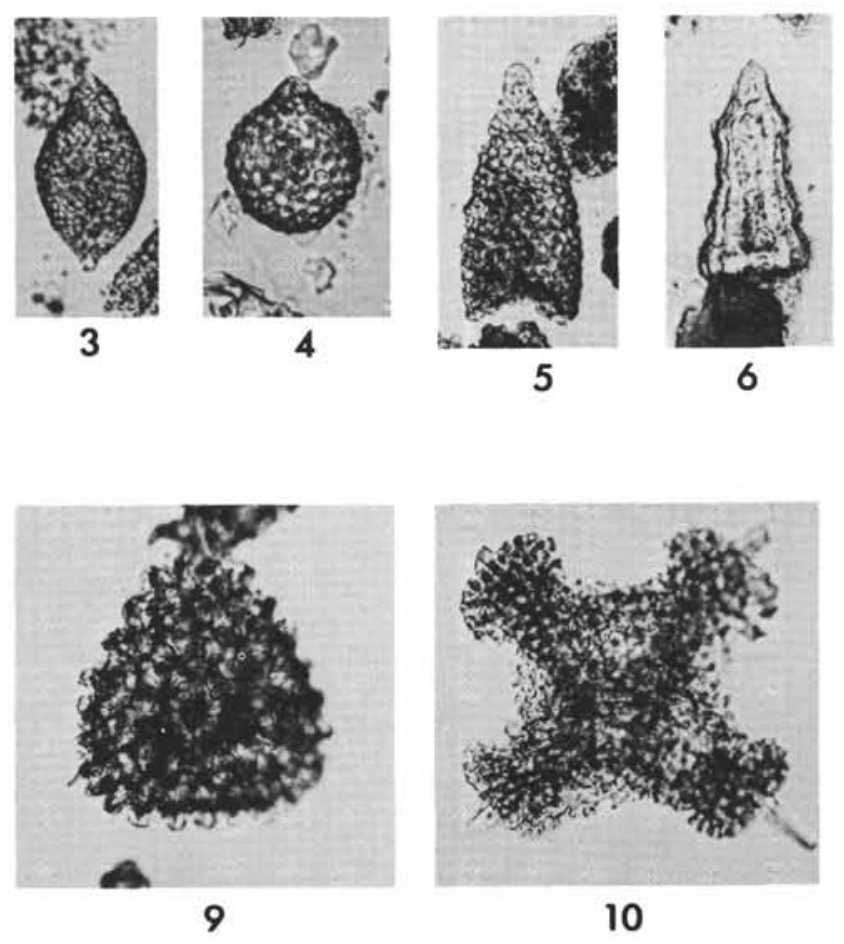

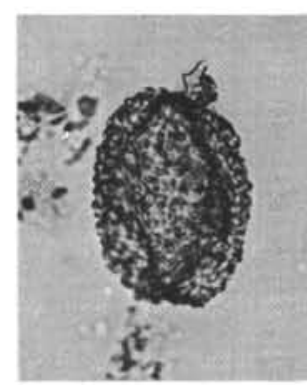

12

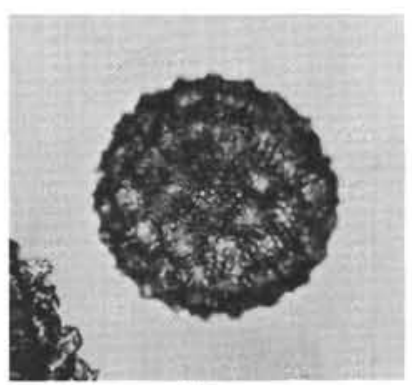

13

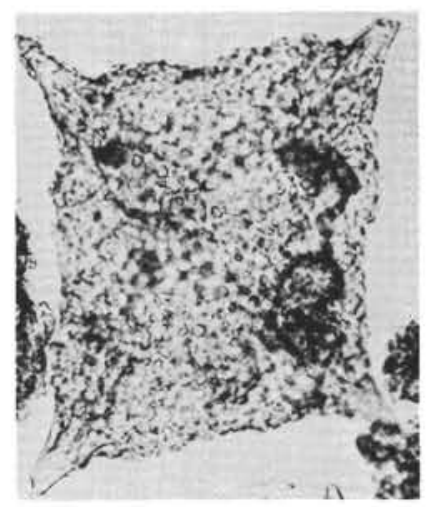

14

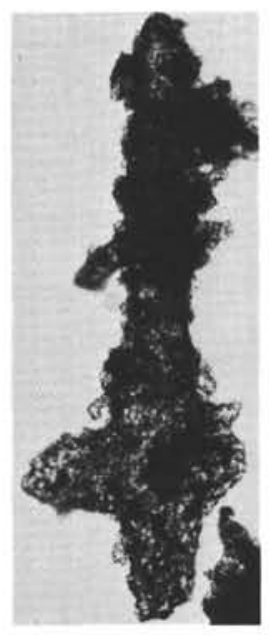

18

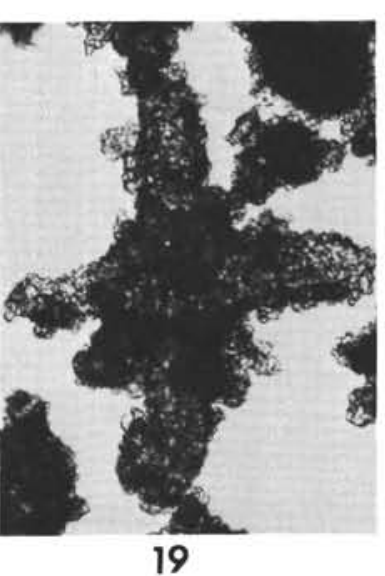

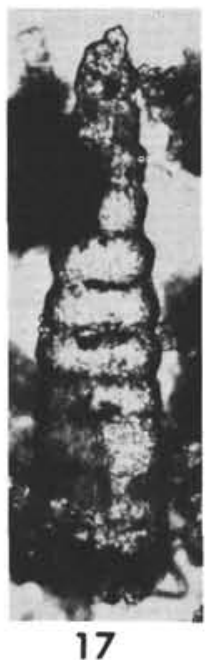

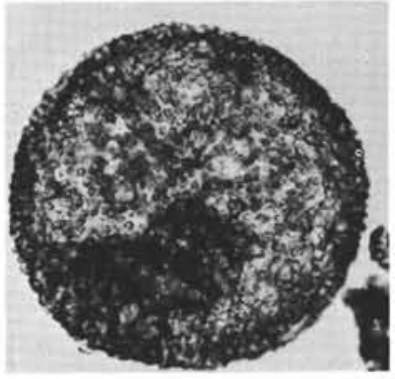

15

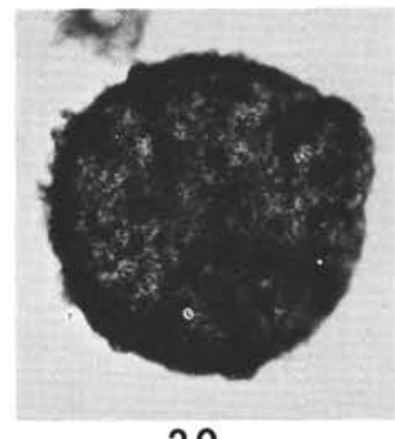




\section{INDEX OF RADIOLARIAN NAMES}

Genus and species - group taxa are indexed (and in a few cases family groups when species referred to as gen. and sp. indet. are included). In order to facilitate use of the index for taxa for which there are many entries, the principal reference and illustrations are printed in bold face, and these are preceded by entries referring to brief mentions in discussion and followed by entries referring to occurrences and stratigraphic range.

\section{Acanthocyrtis, 431}

Actinommidae

Gen. and sp. indet., 429, pl. 13, fig. 13;429, pl. 13, fig. 11, pl. 13, fig. 20

Alievium, 429

gallowayi, $429 ;$ pl. 13 , fig. 9

Amphipternis, 430

claya, 430 ; pl. 7, fig. 16, 17; pl. 9, fig. 2; fig. 7; tables 1 b, 2b, 3b, $4 \mathrm{~b}, 6$

sp. cf. (?) Stichomitra alamedaensis, 430 ; pl. 7, fig. 18; pl. 9, fig. 1 ; tables $1 b, 2 b, 3 b, 4 b, 6 ; 423$

Amphipyndax, 430

stocki, 430 , pl. 13 , fig. 5

sp. cf. A. stocki, 430

Anthocyrtis (?) ficus, 441

hispida, 434

Artophormis, 432

barbadensis, 432; tables 1a, 2a, 3a, 4a, 5a, 6

dominasinensis, 432; tables 1a, 2a, 3a, 4a, 5a, 6

gracilis, 432; tables 1a, 2a, 3a, 4a, 5a, 6

Artostrobium, 433, 430, 431

dolioluom, 431

miralestense, 431; tables 1a, 2a, 3a, 4a, 5a, 6

tina, 430

urna, 431

sp. aff. A. doliolum, 431; tables 1a, 2a, 3a, 4a, 5a, 6

Baculogypsina (?) gallowayi, 429

Bekoma, 433, 437, 432

bidarfensis, $433,437,432$; pl. 3 , fig. 20, 21 ; pl. 10, fig. 6 ; tables $1 \mathrm{~b}, 2 \mathrm{~b}, 3 \mathrm{~b}, 4 \mathrm{~b}, 6$

campechensis, 423, 433, 432; pl. 3, fig. 24; pl. 10, figs. 1, 2; fig. 4 ; tables $1 \mathrm{~b}, 2 \mathrm{~b}, 3 \mathrm{~b}, 4 \mathrm{~b}, 6$

(?) demissa, 423, 432; pl. 3, fig. 22; pl. 10, fig. 5; fig. 6; tables $1 \mathrm{~b}$, $2 \mathrm{~b}, 3 \mathrm{~b}, 4 \mathrm{~b}, 5 \mathrm{~b}, 6$

divaricata, 423, 432, 433; pl. 3, fig. 23; pl. 10, figs. 3, 4; tables 1b, 2b, 3b, 4b, 5b, 6; sp., 433

Buryella, 431,433

clinata, $423,425,428,433$; pl. 8 , figs. 1-3; pl. 9, fig. 19; tables $1 \mathrm{~b}, 2 \mathrm{~b}, 3 \mathrm{~b}, 4 \mathrm{~b}, 5 \mathrm{~b}, 6$

pentadica, 423, 428, 433; pl. 8 , fig. 8 ; pl. 9 , figs. 15 , 16; tables $1 \mathrm{~b}, 2 \mathrm{~b}, 3 \mathrm{~b}, 4 \mathrm{~b}, 5 \mathrm{~b}, 6$

tetradica, $423,428,433$; pl. 8 , figs. 4,5 ; pl. 9 , figs. 13,14 ; tables $1 b, 2 b, 3 b, 4 b, 5 b, 6$

Calocyclas, 433

barbadensis, $\mathbf{4 3 2}$

casta, 434

extensa, 439

hispida, 423,434 ; pl. 1 , figs. $12-15$; pl. 9 , fig. 18 ; tables $1 \mathrm{a}, 1 \mathrm{~b}$, 2a, 2b, 3a, 3b, 4a, 4b, 5a, 6

turris, 433, 434; tables 1a, 2a, 3a, 4a, 5a, 6

sp., pl. 1 , fig. 16

Calocycloma, 434

ampulla, 434 ; pl. 1 , figs. $1-5$; pl. 9 , fig. 20 ; tables 1a, 1b, 2a, 2b, $3 \mathrm{a}, 3 \mathrm{~b}, 4 \mathrm{a}, 4 \mathrm{~b}, 5 \mathrm{a}, 6$

(?) ampulla, 434

castum, 425,434 ; pl. 1, figs. 7, 9, 10; tables 1 b, 2b, 3b, 4b, 6 sp. aff. Calocycloma castum, pl. 1, fig. 8

sp., pl. 1, figs. 6,11

Ceratospyris articulata, 425

Clathrocyclas, 434

sp., 439
Clathrocycloma, 431,434

alcmenae, 434

capitaneum, $423,434,435$; pl. 2 , fig. 15 , pl. 11 , fig. 11 , tables $1 b, 2 b, 3 b, 4 b, 6$

parcum, 423,434 ; pl. 2 , fig. 13 ; pl. 11 , fig. 12 ; tables $1 b, 2 b, 3 b$, $4 \mathrm{~b}, 6$

sp. aff. Clathrocycloma capitaneum, pl. 2, fig. 14

spp., pl. 2, figs. 11,12

Coniforma, 434

Crucella, 430, 429

espartoensis, 429

sp. cf. Crucella espartoensis, 429 , pl. 13, fig. 14

sp., 429; pl. 13, fig. 10

spp., pl. 13, figs. 18,19

Cycladophora, 434

enneapleura, 435

hispida, 434

stiligera, 434

tabulata, 434

turris, 434

Cyclampterium, 435

(?) leptetrum, 435 ; tables 1a, 2a, 3a, 4a, 5a, 6

(?) milowi, 435; tables 1a, 2a, 3a, 4a, 5a, 6

(?) pegetrum, 435; tables 1a, 2a, 3a, 4a, 5a, 6

sp., table 2a

Cyrtocalpis fabaeformis, 436

Cyrtocapsa cormuta, 435

diploconus, 439

tetrapera, 435

Cyrtocapsella, 435

cornuta, 435 ; tables 1a, 2a, 3a, 4a, 5a, 6

elongata, 435; tables 1a, 2a, 3a, 4a, 5a, 6

japonica, tables 1a, 2a, 3a, 4a, 5a

tetrapera, 435; tables 1a, 2a, 3a, 4a, 5a, 6

Cyrtocorys, 430

Cyrtophormis armata, 439

corona, 431

Dendrospyris acuta, 425

turriturcica dasyotus, 425

turriturcica turriturcica, 425

Dicolocapsa verbeeki, 429

Dictyocephalus amphora, 431

ampulla, 434

miralestensis, 431

pulcherrimus, 432

urceolus, 432

Dictyoceras, 435 caia $, 423,435$; pl. 2 , fig. 7 ; pl. 9 , fig. 21 ; tables 1 b, 2b, 3b, 4 b, 6

Dictyomitra, 430

multicostata, 430

torquata , $430 ;$ pl. 13 , fig. 7

sp., 430 ; pl. 13, fig. 6

spp., pl. 13, figs. 16, 17

Dictyophimus babylonis, 437

Dictyoprora, 432

Dictyospyris gigas, 425

melissium, 425

Eucyritidium ampulla, 434

armadillo, 432

biauritum, 442

bicorne, 442

clava, 430

cryptocephalum, 440

cubense, 438

delmontense, 439

embolum, 440

ficus, 441

fistuligerum, 435

lineata, 431 
mongolfieri, 432

pirum, 432

stephanophorum, 442

Eucyrtis, 439

Eusyringium, 435

fistulagerum, 435 ; pl. 11, fig. 6; tables 1a, 1b, 2a, 2b, 3a, 3b, 4a, $4 \mathrm{~b}, 5 \mathrm{a}, 6$

lagena (?), 435; pl. 11, figs. 4, 5; tables $1 \mathrm{~b}, 2 \mathrm{~b}, 3 \mathrm{~b}, 4 \mathrm{~b}, 6$

spongoconum, 440

Giraffospyris cyrillium, 425

lata, 425

Gongylothorax, 429

verbeeki, 429 ; pl. 13, fig. 4

Lamprodiscus, 437

monocerus, 437

Lamptonium, $436 ; 435$

(?) colymbus, $423 ; 436$; 435; pl. 6, fig. 2 ; pl. 11, figs. 15, 19; tables $1 \mathrm{~b}, 2 \mathrm{~b}, 3 \mathrm{~b}, \mathbf{4 b}, 6$

fabaeforme (?) chaunothorax, 425; 428; 435; 436; pl. 6, figs. 10-12; tables $1 \mathrm{~b}, 2 \mathrm{~b}, 3 \mathrm{~b}, 4 \mathrm{~b}, 6$

(?) fabaeforme (?) chaunothorax, 436

fabaeforme (?) constrictum, $425 ; 428 ; 435 ; 436 ;$ pl. 6 , figs. 13 , 14 ; tables $1 \mathrm{~b}, 2 \mathrm{~b}, 3 \mathrm{~b}, 4 \mathrm{~b}, 6$

(?) fabaeforme (?) constrictum, 436

fabaeforme fabaeforme (?), 435; 436; 425; 428; pl. 6, figs. 6-9; tables $1 \mathrm{~b}, 2 \mathrm{~b}, 3 \mathrm{~b}, 4 \mathrm{~b}, 6$

(?) fabaeforme fabaeforme (?), 436

(?) incohatum, $423 ; 435 ; 436$; pl. 6, fig. 1; pl. 11, fig. 18; tables $1 \mathrm{~b}, 2 \mathrm{~b}, 3 \mathrm{~b}, 4 \mathrm{~b}, 6$

pennatum, $435 ; 436 ; 423 ; 425,428$; pl. 6 , figs. $3-5$; pl. 11, fig. 13 ; tables $1 \mathrm{~b}, 2 \mathrm{~b}, 3 \mathrm{~b}, 4 \mathrm{~b}, 6$

sanfilippoae, $425 ; 435 ; 436$; pl. 6, figs. 15, 16; pl. 11, figs. 16, 17; tables $1 \mathrm{~b}, 2 \mathrm{~b}, 3 \mathrm{~b}, 4 \mathrm{~b}, 6$

Lamptonium (?), 436

Lithapium plegmacantha, 425

Lithelius hexaxyphophorus, 425

Lithocampe clava, 430

(?) clava, 430

corbula, 431

lineata, 431

turgida, 438

sp., 433

Lithocampium sp. A., 433

sp., 433

Lithochytris, 436

archaea, 416; 429; 437; 436; pl. 2, figs. 4, 5; tables 1b, 2b, 3b, $4 \mathrm{~b}, 6$

vespertilio, 416 ; $423 ; 429 ; 437 ; 439 ; 436$; pl. 2, figs. 2 , 3; pl. 11, fig. 3 ; tables $1 \mathrm{~b}, 2 \mathrm{~b}, 3 \mathrm{~b}, 4 \mathrm{~b}, 6$

Lithocyclia ocellus group, 425

Lithomitra, 431

docilis, 423; 431; pl. 8, figs. 20-22; pl. 9, figs. 3-5; tables 1a, 1 b, $2 \mathrm{a}, 2 \mathrm{~b}, 3 \mathrm{a}, 3 \mathrm{~b}, 4 \mathrm{a}, 4 \mathrm{~b}, 5 \mathrm{a}, 6$

lineata, 431

lineata group, $431 ;$ pl. 8 , fig. 19

sp. aff. Lithomitra lineata group, 432; 431; tables 1a, 2a, 3a, 4a, 5 a, 6

sp. cf. Lithomitra lineata group, pl. 8, fig. 18

Lithopera, 436

lagena, $\mathbf{4 3 5}$

renzae, 436 ; tables $1 \mathrm{a}, 2 \mathrm{a}, 3 \mathrm{a}, 4 \mathrm{a}, 5 \mathrm{a}, 6$

Lithornithium dictyoceras, 435

foveolatum, 439

Lophocyrtis, $436 ; 442$

biaurita , 423; 442; pl. 8, figs. 23-26; tables 1b, 2b, 3b, 4b, 6

(?) jacchia , 436; tables 1a, 2a, 3a, 4a, 5a, 6

Lychnocanium, 437

amphitrite, 408

bellum, 437

lucerna, 437

sp. aff. Lychnocanium bellum, 437

sp., 437
Lychnocanoma, 437

amphitrite, 429; 437; pl. 11, fig. 10; tables 1a, 2a, 3a, 4a, 5a, 6 anacolum, 423, 437; pl. 1, fig. 19; pl. 11, fig. 7; tables 1b, 2b, 3b, $4 \mathrm{~b}, 6$

auxilla, $429 ; 437 ; 439 ; 437$; pl. 2, fig. 6, pl. 11, figs. 1, 2; tables $1 b, 2 b, 3 b, 4 b, 6$

babylonis group, 429; 437; pl. 2, fig. 1; tables 1a, 1b, 2a, 2b, 3a, $3 \mathrm{~b}, 4 \mathrm{a}, 4 \mathrm{~b}, 5 \mathrm{a}, 6$

bellum , 429 ; 437 ; pl. 1, fig. 17; pl. 11, fig. 9; tables 1a, 1b, 2a, $2 \mathrm{~b}, 3 \mathrm{a}, 3 \mathrm{~b}, 4 \mathrm{a}, 4 \mathrm{~b}, 5 \mathrm{a}, 6$

bipes, 437; tables 1a, 2a, 3a, 4a, 5a, 6

clavigerum, 437

sp. aff. Lychnocanoma bellum, 429; 437; pl. 1, fig. 18; pl. 11, fig. 8 ; tables $1 \mathrm{a}, 1 \mathrm{~b}, 2 \mathrm{~b}, 3 \mathrm{~b}, 4 \mathrm{~b}, 6$

Orbula, 437

comitata, 423, 438; 437; pl. 3, fig. 11; pl. 10, figs. 7, 8; fig. 5; tables $1 \mathrm{~b}, 2 \mathrm{~b}, 3 \mathrm{~b}, 4 \mathrm{~b}, 6$

discipulus, 423 ; 438; pl. 3, fig. 10; pl. 10, figs. 9, 10; tables 1 b, $2 \mathrm{~b}, 3 \mathrm{~b}, 4 \mathrm{~b}, 6$

ducalis, $423 ; 437 ; 438$; pl. 3, fig. 12; pl. 10, figs. 11, 12; tables $1 b, 2 b, 3 b, 4 b, 6$

Periphaena decora, 425 delta, 425

Phormocampe alamedaensis, 430

alamedaensis var. tenuis, 430

Phormocyrtis, 438

cubensis, 438; pl. 7, figs. 11, 12, 14; tables 1b, 2b, 3b, 4b, 6 longicornis, 438

striata, 438

striata exquisita, $423 ; 429 ; 438 ;$ pl. 7 , figs. $14,7,8 ;$ pl. 12 , fig. 5 ; tables $1 \mathrm{~b}, 2 \mathrm{~b}, 3 \mathrm{~b}, 4 \mathrm{~b}, 6$

striata striata, $423 ; 425 ; 429 ; 438$; pl. 7 , figs. $5,6,9$; tables $1 \mathrm{~b}$, $2 \mathrm{~b}, 3 \mathrm{~b}, 4 \mathrm{~b}, 6$

turgida, $425 ; 438$; pl. 7 , fig. 10 ; pl. 12 , fig. 6 ; tables $1 \mathrm{~b}, 2 \mathrm{~b}, 3 \mathrm{~b}$, $4 \mathrm{~b}, 6$

Phormostrichoartus, 431

sp. aff. Phormostichoartus corona, 416; 431; tables 1a, 2a, 3a, $4 \mathrm{a}, 5 \mathrm{a}$

Podocyrtis diamesa, 425

dominasinensis, 432

exquisita, 438

grata, 442

hirsutus, 441

platypus, 425

sinuosa, 425

tetracantha, 442

triacantha, 442

Pseudoaulophacus, 429

floresensis, 429 ; pl. 13 , fig. 8

gallowayi, 429

pargueraensis, 429

superbus, 429

Pterocodon, 438

(?) ampla (?), 425; 439; 438; pl. 5, figs. 3-5; tables 1b, 2b, 3b, $4 \mathrm{~b}, 6$

campana, 438

(?) tenellus, 425 , 439; pl. 5, fig. 7 ; pl. 12, fig. 4 ; tables $1 \mathrm{~b}, 2 \mathrm{~b}$, $3 \mathrm{~b}, 4 \mathrm{~b}, 6$

(?) sp., pl. 5 , fig. 6

Rhabdolithis ellida, 425

pipa, 425

Rhopalocanium, 439

ornatum, $423 ; 425 ; 439 ;$ pl. 2, figs. $8-10$; pl. 12 , fig. 3 ; tables 1 b, $2 \mathrm{~b}, 3 \mathrm{~b}, 4 \mathrm{~b}, 6$

pythia, 439

Sethamphora ampulla, 434

Sethocapsa lagena, 435

pyriformis, 435

Sethochytris babylonis, 437 


\section{H. P. FOREMAN}

Sethopera lagena, 435

Siphocampe, 431 sp. aff. Siphocampe corbula, 431; tables 1a, 2a, 3a, 4a, 5a, 6

Spirocyrtis, 431

scalaris, 431

sp. aff. Spirocyrtis scalaris, 431; tables 1a, 2a, 3a, 4a, 6

Spongatractus balbis, 425 pachystylus, 425

Spongodiscidae Gen. and sp. indet., 429 ; pl. 13, fig. 15

Gen. and sp. indet. cf. Spongodiscus multus, 429

Gen. and sp. indet. cf. Spongodiscus (?) multus, 429; pl. 13, fig. 12

Spongodiscus (?) multus, 429 phrix, 425

quartus quartus, 425

Spongomelissa adunca, 425

cucumella, 425

euparyphus, 425

Spongoprunum, 429 sp., 429

Stichocapsa (?) stocki, 430

Stichocorys, 439

armata, 439; tables 1a, 2a, 3a, 4a, 6

delmontensis, 439; tables 1a, 2a, 3a, 4a, 6

diploconus, 439; tables 1a, 2a, 3a, 4a, 6

wolffii, 439 ; tables 1a, 2a, 3a, 4a, 6

Stichomitra alamedaensis, $430 ; 431$

Stichopera ponderosa, 436

Stylosphaera coronata sabaca, 425 goruna, 425

Stylotrochus alveatus, 425 quadribrachiatus multibrachiatus, 425

Thecosphaera larnacium, 425

Thecosphaerella glebulenta, 425

Theocampe, $430 ; 431$

amphora group, 432; 431; pl. 8, figs. 7, 9-13; pl. 9, figs. 8, 9; tables 1a, 1b, 2a, 2b, 3a, 3b, 4a, 4b, 5a, 6

armadillo group, 432; tables 1a, 2a, 3a, 4a, 5a, 6

dactylica, 431

mongolfieri, 425; 432; pl. 8, fig. 6; pl. 9, fig. 17; tables 1a, 1b, 2a, $2 \mathrm{~b}, 3 \mathrm{a}, 3 \mathrm{~b}, 4 \mathrm{a}, 4 \mathrm{~b}, 5 \mathrm{a}, 6$

pirum, 432; pl. 9, figs. 11, 12; tables 1a, 2a, 3a, 4a, 5a, 6

salillum, 430 ; pl. 13, fig. 2

urceolus, $425 ; 432$; pl. 8 , figs. 14-17; pl. 9, figs. 6, 7, 9; tables 1 , $2 \mathrm{a}, 2 \mathrm{~b}, 3 \mathrm{a}, 3 \mathrm{~b}, 4 \mathrm{a}, 4 \mathrm{~b}, 5 \mathrm{a}, 6$

sp. aff. Theocampe amphora group, pl. 9 , fig. 10

Theocapsa elongata, 435

Theoconus ficus, 441

Theocorys, 439

acroria, 429; 440; 439; pl. 5, figs. 11-13; pl. 12, fig. 2; tables 1b, $2 \mathrm{~b}, 3 \mathrm{~b}, 4 \mathrm{~b}, 6$ anaclasta, 429; 439; pl. 5, figs. 14, 15; tables 1 b, 2b, 3b, 4b, 6 anapographa, 429; 439; pl. 5, figs. 9, 10; tables 1b, 2b, 3b, 4b, 6 morchellula, 439

(?) phyzella $425 ; 439 ; 440$; pl. 5 , fig. 8 ; pl. 12, fig. 1 ; tables 1 b, $2 \mathrm{~b}, 3 \mathrm{~b}, 4 \mathrm{~b}, 6$

spongoconum, 440

(?) spongoconum, 439; 440; tables 1a, 2a, 3a, 4a, 5a, 6

trisulca, 433

unicum, $438 ; 439$

sp. aff. Theocorys (?) spongoconum, pl. 11, fig. 14

sp., 440

Theocotyle, 440

alpha, 425 ; $428 ; 441$; pl. 4, figs. 13-15; pl. 12, fig. 16; tables 1 b, $2 \mathrm{~b}, 3 \mathrm{~b}, 4 \mathrm{~b}, 6$

auctor, $425 ; 428 ; 440 ; 441 ;$ pl. 4 , figs. $8-10 ;$ pl. 12 , fig. 13 ; tables $1 \mathrm{~b}, 2 \mathrm{~b}, 3 \mathrm{~b}, 4 \mathrm{~b}, 6$

cryptocephala (?) conica, $428 ; 440 ;$ pl. 4 , fig. $11 ;$ pl. 12 , figs. 19 , 20 ; tables 1 b, 2b, 3b, 4b, 6

cryptocephala cryptocephala (?), 425; 429; 440; pl. 4, figs. 6, 7; pl. 12, fig. 18; tables $1 \mathrm{~b}, 2 \mathrm{~b}, 3 \mathrm{~b}, 4 \mathrm{~b}, 6$

cryptocephala (?) nigriniae, $425 ; 429 ; 440 ; 441 ; 442 ; 440 ;$ pl. 4, figs. 1-5, pl. 12, fig. 17, tables 1b, 2b, 4b, 6

ficus, $423 ; 425 ; 428 ; 440 ; 441$; pl. 4, figs. 16-20; tables 1 b, 2 b, $3 \mathrm{~b}, 4 \mathrm{~b}, 6$

(?) ficus, 441

(?) fimbria, $440 ; 441$; pl. 5 , figs. 1, 2; pl. 12, fig. 21 ; tables 1 b, $2 \mathrm{~b}, 3 \mathrm{~b}, 4 \mathrm{~b}, 6$

venezuelensis, $440 ;$ pl. 4 , fig. 12

Theocotylissa, $\mathbf{4 4 0}$

Theocyrtis ampla, 439

(?) Theopera fusiformis, 439

Theoperidae

Gen. and sp. indet., 429 ; pl. 13, fig. 1, 3

Thyrsocyrtis, 441

bromia, 441 ; tables 1a, 2a, 3a, 4a, 5a, 6

hirsuta hirsuta, $425 ; 428 ; 442 ; 441$; pl. 3, figs. 3-8; pl. 12, fig. 15; tables $1 \mathrm{~b}, 2 \mathrm{~b}, 3 \mathrm{~b}, 4 \mathrm{~b}, 6$

hirsuta robusta, $425 ; 428 ; 442$; pl. 3 , fig. 17 ; tables $1 \mathrm{~b}, 2 \mathrm{~b}, 3 \mathrm{~b}$, $4 \mathrm{~b}, 6$

hirsuta tensa, $425 ; 428 ; 442$; pl. 3 , figs. $13-16$; pl. 12, fig. 8 ; tables $1 \mathrm{~b}, 2 \mathrm{~b}, 3 \mathrm{~b}, 4 \mathrm{~b}, 6$

jacchia, 436

rhizodon, 440; 441; 442; pl. 3, figs. 1, 2; tables 1a, 1b, 2a, 2b, $3 \mathrm{a}, 3 \mathrm{~b}, 4 \mathrm{a}, 4 \mathrm{~b}, 5 \mathrm{a}, 6$

tarsipes, $425 ; 428 ; 441 ; 442$; pl. 3, fig. 9; pl. 12, fig. 14; tables 1b, $2 \mathrm{~b}, 3 \mathrm{~b}, 4 \mathrm{~b}, 6$

tetracantha, 425; 428;442; tables 1a, 2a, 3a, 4a, 5a, 6

triacantha , $425 ; 428 ; 442$; pl. 12, figs. 9-11; tables $1 \mathrm{a}, 1 \mathrm{~b}, 2 \mathrm{a}, 2 \mathrm{~b}$, $3 \mathrm{a}, 3 \mathrm{~b}, 4 \mathrm{a}, 4 \mathrm{~b}, 5 \mathrm{a}, 6$

sp. A. aff. Gen. et sp. indet. Riedel and Sanfilippo, 1970, (pl. 8, fig. 4 ), pl. 3 , figs. 18,19 ; pl. 12 , fig. 7

sp. B, pl. 12, fig. 12

Tricolocampe vitrea, 438 ; pl. 7 , fig. 13 